\title{
OIL PALM AND RUBBER TREE TRANSPIRATION: \\ TOPOGRAPHY, FLOODING AND \\ TREE ADMIXTURE IN JUNGLE RUBBER STANDS
}

\author{
Dissertation \\ zur Erlangung des akademischen Grades Doctor of Philosophy (PhD) \\ der Fakultät für Forstwissenschaften und Waldökologie \\ der Georg-August-Universität Göttingen
}

vorgelegt von

Afik Hardanto

(geboren in Bantul, Indonesia)

Göttingen, January 2017 
1. Gutachter: Prof. Dr. Dirk Hölscher

2. Gutachter: Prof. Dr. Alexander Knohl

3. Gutachter: Prof. Dr. Hermann Behling

Tag der müdlichen Prüfung: 16.03.2017 
... Davi Jan hanya untuk-OYya 


\section{Table of contents}

Table of contents

Abstract

Zusammenfassung .

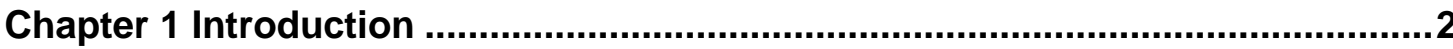

1.1 Expansion of oil palm and rubber plantation ........................................ 2

1.2 Spatial and temporal variability influence water use pattern of oil palm and

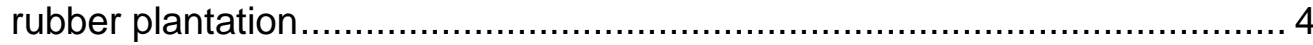

1.3 Searching "greener" of oil palm and rubber plantation ............................. 5

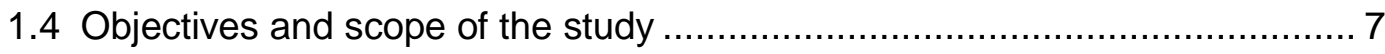

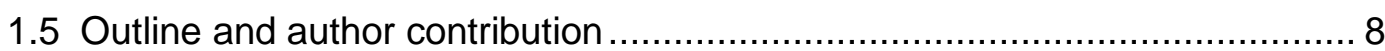

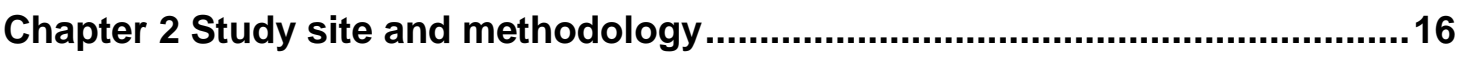

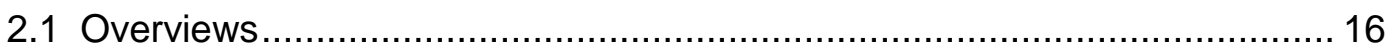

2.2 Studied plot and EFForTS design .................................................... 17

2.3 Sap flux density, water use and transpiration...................................... 18

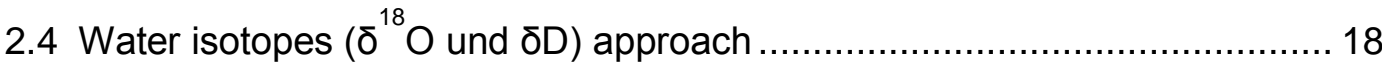

2.5 Soil moisture and meteorological measurements................................... 19

Chapter 3 Oil palm and rubber tree water use patterns: effects of

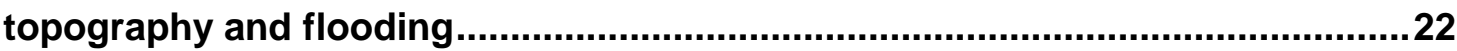

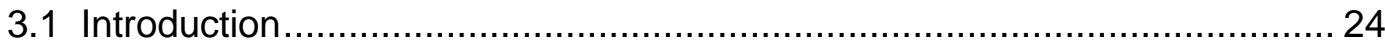

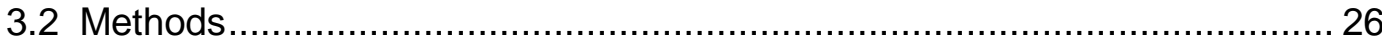

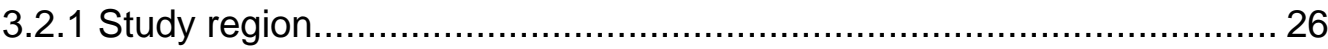

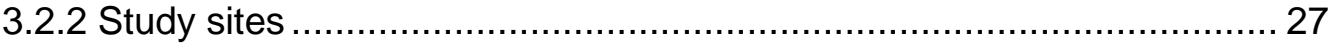

3.2.3 Sap flux measurements and transpiration .................................... 28

3.2.4 Soil water content .................................................................... 29

3.2.5 Micrometeorological variables.................................................... 29

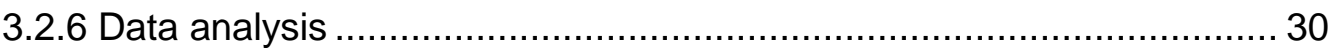

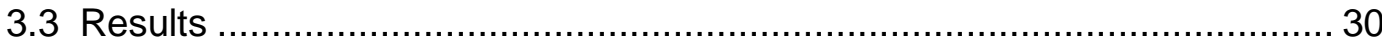

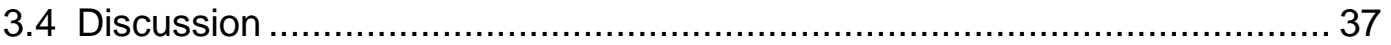

Chapter 4 Tree soil water uptake and transpiration in mono-cultural and

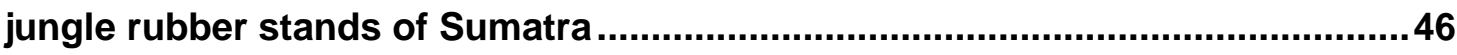

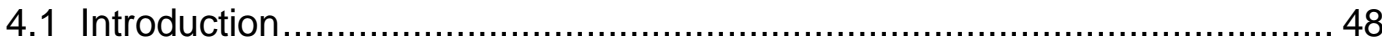

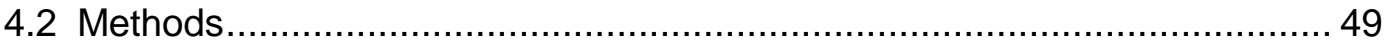




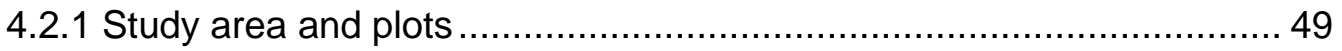

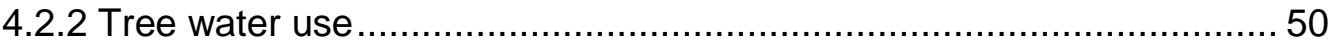

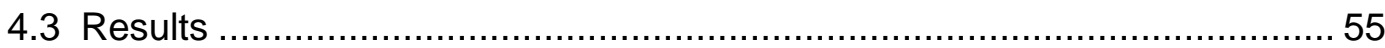

4.3.1 Tree water use and stand transpiration ....................................... 55

4.3.2 Tree soil water uptake............................................................ 55

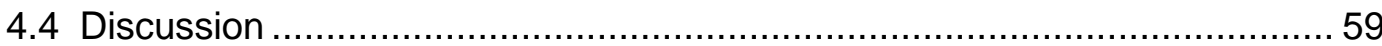

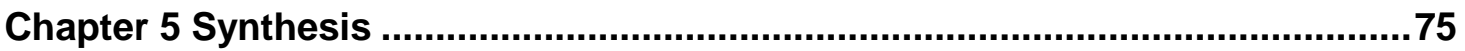

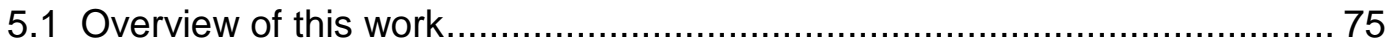

5.2 Topography and flooding influence on transpiration.............................. 75

5.3 Mixed-culture cultivation systems ................................................... 77

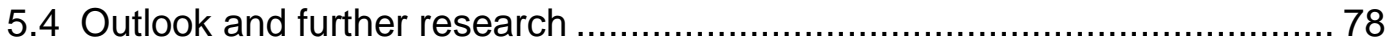

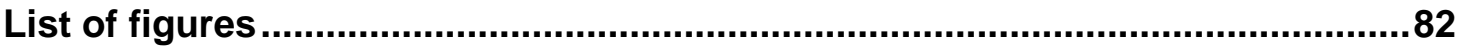

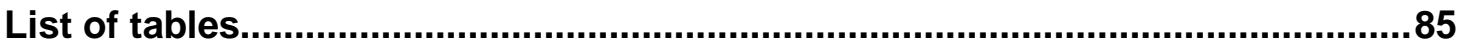

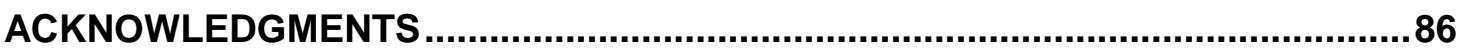

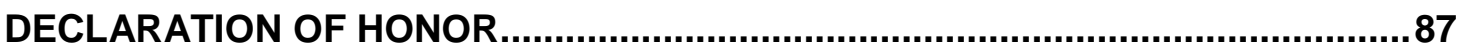

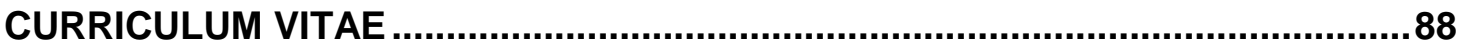




\section{Abstract}

In post-forest plantation landscapes of lowland Sumatra, I studied (1) effects of topography and flooding on transpiration by mono-cultural oil palm and rubber tree plantations, and (2) tree water use rates and tree soil water uptake depths in monocultural and mixed 'jungle' rubber stands.

Oil palm and rubber plantations extend over large areas and encompass heterogeneous site conditions. In periods of high rainfall, plants in valleys and at riparian sites are more prone to flooding than plants at elevated topographic positions. I asked to what extent topographic position and flooding affect oil palm and rubber tree water use patterns and thereby influence spatial and temporal heterogeneity of transpiration. In an undulating terrain in the lowlands of Jambi, Indonesia, plantations of the two species were studied in plot pairs consisting of upland and adjacent valley plots. All upland plots were non-flooded, whereas the corresponding valley plots included non-, long-term and short-term flooded conditions. Within each plot pair, sap flux densities in palms or trees were monitored simultaneously with thermal dissipation probes. In plot pairs with non-flooded valleys, sap flux densities of oil palms were only slightly different between the topographic positions, whereas sap flux densities of rubber trees were higher in the valley than at the according upland site. In pairs with long-term flooded valleys, sap flux densities in valleys were lower than at upland plots for both species, but the reduction was far less pronounced in oil palms than in rubber trees $(-22 \%$ and $-45 \%$ in maximum sap flux density, respectively). At these long-term flooded valley plots palm and tree water use also responded less sensitively to fluctuations in micrometeorological variables than at upland plots. In short-term flooded valley plots, sap flux densities of oil palm were hardly affected by flooding, but sap flux densities of rubber trees were reduced considerably. Topographic position and flooding thus affected water use patterns in both oil palms and rubber trees, but the changes in rubber trees were much more pronounced: compared to non-flooded upland sites, the different flooding conditions at valley sites amplified the observed heterogeneity of plot mean water use by a factor of 2.4 in oil palm and by a factor of 4.2 in rubber plantations.

Rubber tree mono-cultural plantations are expanding and there is also a search for 'green' rubber production. Rubber tree cultivation in stands with admixed spontaneously growing native trees, called 'jungle rubber', has a long tradition in Sumatra. The objectives of my study were to analyze tree water use rates and tree 
soil water uptake depths in mono-cultural and mixed 'jungle' rubber stands with a focus on the role of tree diameter. Sap flux measurements suggest similar water use rates for rubber trees in the two cultivation systems. The increase in tree water use with tree diameter was however much stronger for rubber trees than for the admixed native tree species. At the stand-level, transpiration of jungle rubber was by $27 \%$ higher than of rubber monocultures, which was mainly due to the higher stem density in the jungle rubber stands. In these stands, the share of rubber trees of the total transpiration corresponded with its' share to total tree basal area. A water stable isotope $\left(\delta^{18} \mathrm{O}\right.$ and $\left.\delta \mathrm{D}\right)$ approach suggests different soil water uptake depths for the rubber trees in the two cultivation systems. In a dry period, the main tree water uptake in the monoculture was relatively close to the soil surface, whereas rubber trees in the jungle rubber mainly took up water from deeper in the soil profile. The admixed native trees in the jungle rubber had their main uptake depth relatively close to the soil surface. This pattern indicates competitive displacement of the rubber tree water uptake. Across rubber trees in both cultivation systems and also among the admixed native trees, there was a clear relationship between tree diameter and soil water uptake depth: bigger trees tended to take up soil water closer to the soil surface.

Overall, my study revealed strong differences between oil palms and rubber tree transpiration in response to topography and flooding. Such a pronounced heterogeneity of water use across space and time may be of relevance for ecohydrological assessments of tropical plantation landscapes. The comparison monocultural and mixed 'jungle' rubber stands suggests, that rubber trees are relatively weak competitors for water resource uptake, and tree diameter modifies both tree water use rates and tree water uptake depths. The diameter relationship offers opportunities for management interventions in favor of the rubber trees. Mixed species cultivation systems in oil palm with native tree species have only recently been established and are awaiting their evaluation. 


\section{Zusammenfassung}

In der vorliegenden Arbeit befasste ich mich mit Waldplantagen im sumatraischen Tiefland und untersuchte (1) die Auswirkung von Topographie und Überschwemmung auf die Transpirationsleitstung von Ölpalmen- und Kautschukmonokulturen, und (2) die Wasserflussraten sowie die Tiefe der Bodenwasseraufnahme aus der die Pflanzen der Monokulturen und der Dschungel-Kautschukplantagen ihr Wasser entnehmen.

Ölpalmen- und Kautschukplantagen erstrecken sich über große Flächen und umfassen heterogene Standortbedingungen. In Zeiten mit hohem Niederschlag sind Pflanzen in Tälern und an Uferbereichen anfälliger für Überschwemmungen als Pflanzen in erhöhten topographischen Positionen. Ich untersuchte inwieweit die topographische Lage und die Überschwemmungen Ölpalmen- und Kautschukwassernutzung beeinflussen und damit die räumliche und zeitliche Heterogenität der Transpiration verändern. In dem hügeligen Gelände im Tiefland von Jambi, Indonesien wurden Plantagen beider Arten in Versuchsflächenpaaren untersucht die jeweils aus Hochland und angrenzenden Talgrundstücken bestanden. Alle Hochland Versuchsflächen wurden nicht überschwemmt, während die entsprechenden Tal Versuchsflächen ebenfalls nicht- oder aber kurzfristige und langfristige überschwemmte Bedingungen einschlossen. Innerhalb jedes Versuchsflächenpaars wurden Saftlussdichten in Ölpalmen oder Bäumen gleichzeitig mit der sog. „Thermal Dissipation Probes“ Saftflussmessungsmethode gemessen. In den Versuchsflächen mit nicht gefluteten Tälern waren die Saftflussdichten der Ölpalmen zwischen den topographischen Positionen nur geringfügig unterschiedlich, während die Saftflussdichten von Kautschukbäumen im Tal höher waren als im entsprechenden Hochlandgebiet. In den Versuchsflächenpaaren mit langfristig gefluteten Tälern waren die Saftflussdichten in Tälern für beide Arten niedriger als im Hochland, aber die Reduktion war in Ölpalmen weit weniger ausgeprägt als in Kautschukbäumen (-22\% bzw. $-45 \%$ der maximalen Saftflussdichten). Bei diesen langfristig gefluteten Talgrundstücken reagierte die Saftflussdichte von Ölpalmen und Kautschukbäumen weniger empfindlich auf Schwankungen in mikrometeorologischen Variablen als auf den Hochlandversuchsflächen. In kurzzeitigen gefluteten Tälern wurden die Saftflussdichten der Ölpalme kaum durch die Überschwemmung beeinflusst, die der Kautschukbäume jedoch beträchtlich reduziert. Topographische Lage und Überschwemmung beeinflussten also die Wassernutzungsmuster sowohl 
bei Ölpalmen als auch bei Kautschukbäumen, aber die Veränderungen in den Kautschukbäumen waren deutlich ausgeprägter: Im Vergleich zu nicht überschwemmten Hochlandstandorten verstärkten die unterschiedlichen Überschwemmungsbedingungen an Tälern die beobachtete Heterogenität des Wasserverbrauch im Versuchsflächenmittel um Faktor 2,4 in Ölpalmenplantagen und um Faktor 4,2 in Kautschukplantagen.

Kautschukmonokultur Plantagen expandieren und so gibt es die Forderung nach einer "grünen" Kautschuk Produktion. Der Kautschukanbau in mit einheimischen Baumarten gemischten Beständen hat eine lange währende Tradition in Sumatra und wird "Dschungel-Kautschuk" genannt. Die Ziele meiner Arbeit waren die Analyse der Baumwassernutzung und der Tiefe der Baumwasseraufnahme in den Monokulturen und den Dschungel-Kautschukständen mit Schwerpunkt auf der Bedeutung des Baumdurchmessers. Die Saftflussmessungen deuten auf ähnliche Wasserverbrauchsraten der Kautschukbäume in den beiden Anbausystemen hin. Der Anstieg der Baumwassernutzung mit Baumdurchmesser war jedoch viel stärker für Kautschukibäume als für die eingemischten einheimischen Baumarten. Auf der Bestandesebene war die Transpiration von Dschungel-Kautschuk um 27\% höher als bei den Kautschuk Monokulturen, was vor allem auf die höhere Stammdichte in den Dschungel-Kautschukständen zurückzuführen ist. In diesen Beständen korrelierte der Anteil der Gesamttranspiration der Kautschukbäume mit dem Anteil an der Gesamtgrundfläche. Eine Analyse der stabilen Isotope $\delta^{18} \mathrm{O}$ und $\delta D$ des Bodenwassers zeigte unterschiedliche Bodenwasseraufnahmetiefen für die Kautschukbäume in den beiden Kultivierungssystemen. In einer Trockenperiode erfolgte die Hauptwasseraufnahme der Monokultur relativ öberflächennah, während die Bäume im Dschungel-Kautschuk hauptsächlich Wasser aus tieferliegenden Bodenhorizonten aufnahmen. Die eingemischten einheimischen Bäume im Dschungel-Kautschuk hatten ihre Hauptaufnahmetiefe relativ nahe an der Bodenoberfläche. Dieses Phänomen deutet auf eine kompetitive Verschiebung der Kautschukwasseraufnahme hin. Desweiteren gab es zwischen den Kautschukbäumen beider Anbausysteme als auch unter den eingemischten einheimischen Bäumen eine klare Beziehung zwischen dem Baumdurchmesser und der Bodenwasseraufnahmetiefe: Größere Bäume neigten dazu, das Bodenwasser näher an der Bodenoberfläche aufzunehmen. 
Insgesamt zeigte meine Studie starke Unterschiede zwischen Ölpalmen- und Kautschukbaumtranspiration als Reaktion auf Topographie und Überschwemmungen. Eine solche ausgeprägte Heterogenität der Wasserverwendung über Raum und Zeit kann für die ökohydrologische Bewertung tropischer Plantagenlandschaften von Bedeutung sein. Der Vergleich monokultureller und gemischter DschungelKautschukbestände legt nahe, dass Gummibäume relativ schwache Konkurrenten für die Wasserressourcenaufnahme sind, und der Baumdurchmesser die Magnitude der Wasserverwendung sowie die Baumwasseraufnahmetiefen beeinflusst. Die Durchmesserbeziehung bietet gute Möglichkeiten für Managementinterventionen zugunsten der Kautschukbäume. Mischkultivierungssysteme in der Ölpalme mit einheimischen Baumarten wurden erst kürzlich eingerichtet und ihre Bewertung steht noch aus. 
CHAPTER 1

INTRODUCTION 


\section{Chapter 1 Introduction}

\subsection{Expansion of oil palm and rubber plantation}

Forests serve human economy, welfare and also regulate environmental processes such as carbon absorption and storage, biodiversity protection and soil-water conservation (Mittermeier et al., 1998; Mercer and Aruna, 2000; Bruijnzeel, 2004; Saatchi et al., 2011). In the hydrological cycle, precipitation flows to the ocean (i.e. by runoff and groundwater) or returns to the atmosphere by evapotranspiration. Eltahir and Bras (1994) argue that land surface is the main control of the hydrological cycle and further assumed that tropical rain forest can return $25-35 \%$ of total precipitation by evapotranspiration. Unfortunately, in the last decade deforestation reached around 2.3 million $\mathrm{km}^{2}$ and is potentially increasing especially in tropical regions like Indonesia (Hansen et al., 2013). Margono et al. (2014) reported a dramatic decrease in primary rain forest and the highest annual tropical deforestation in Indonesia. The driving force of higher deforestation is the demand for forest resources and agricultural land (Angelsen, 1995; DeFries et al., 2010; Gibbs et al., 2010). For example in Sumatra and Kalimantan, the highest primary forest loss areas in Indonesia (Fig. 1.1a), the expanding plantations of oil palm and rubber are the major drivers (Margono et al., 2014; Abood et al., 2015; Clough et al., 2016; Gaveau et al., 2016).

Indonesia is the world's foremost palm oil and rubber producing country in the last decade, with potential increases (Clough et al., 2016; FAO, 2016; van der Laan et al., 2016). Indonesia has experienced steady rise in oil palm production with estimated annual production of 36 million tons in 2000 to 126.5 million tons in 2014 (FAO, 2016). This trend is expected to continue as global oil palm demand and population keeps increasing (Corley, 2009). Sumatra Island has the largest oil palm plantations

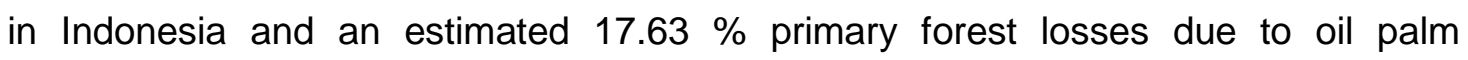
plantation expansion occurred in this region during 2000 to 2012 (Margono et al., 2014). Similar to oil palm trend, Indonesia produced around 1.5 million tons of natural rubber in 2000 and two-fold higher in 2014 (FAO, 2016). Due to increasing market demand by industries, there is rubber plantation expansion in Indonesia and expected to continue to the future with Sumatra contributing to two-thirds of national latex production (Research and Markets, 2016; van der Laan et al., 2016). In the lowland of Jambi (study region), Clough et al. (2016) observed increasing oil palm and rubber plantation in the last decade (Fig. 1.1b). 
Increasing intensive plantation (i.e. oil palm and rubber plantation) follows rising economic income, at local and national level, thus farmer prefer to choose intensive monoculture plantation. At the local scale such as Bungo district of Jambi, farmers who cultivate oil palm and rubber can improve their livelihoods rapidly due to higher income (Feintrenie et al., 2010). Further in the regional and national level, Bahroeny (2009) noted that oil palm is the pillar of Indonesian economy and key to rural development with around 14 million people employed in oil palm plantation. On the other hand, negative effect of intensive plantation expansion such as biodiversity loss, decreasing ecological services and disturbance of eco-hydrological function were revealed. Wilcove et al. (2013) reported a biodiversity crisis in Southeast Asia, the hottest hotspot (Myers et al., 2000), due to intensive agriculture (i.e. oil palm and rubber plantation). Soil microbial community were significantly declined as a result of rainforest transformation to oil palm and rubber plantations in Sumatra (Krashevska et al., 2015). Furthermore, Clough et al. (2016) reported falling ecological services due to transformation from rain forest to oil palm and rubber plantation in lowlands of Jambi. In eco-hydrological impact, Merten et al. (2016) reported periodic regional water scarcity due to higher transpiration and run off of oil palm dominated area. Intensive rubber monoculture in Mainland Asia was also reported as "water pump" due to high transpiration (Tan et al., 2011).
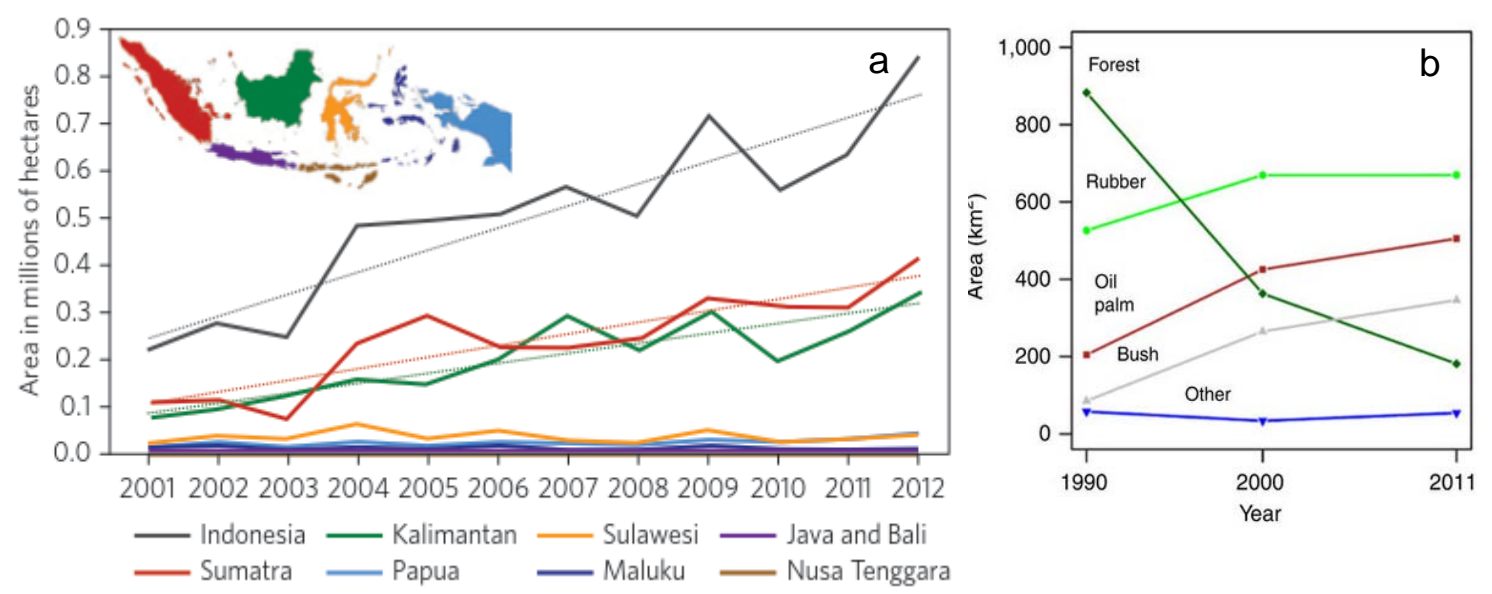

Figure 1.1. (a) Annual primary forest covers loss in Indonesia during 2000-2012 (Margono et al., 2014). (b) Land use change, 1990-2011, for two landscape region (i.e. Bukit duabelas and Harapan region) in lowland of Jambi (Clough et al., 2016). 


\subsection{Spatial and temporal variability influence water use pattern of oil palm and rubber plantation}

In rural regions of mainland Asia and Southeast Asia (e.g. Sumatra, Indonesia) characterized by undulating terrain, oil palm and rubber plantations coverage are conspicuous in the landscape (Gouyon et al., 1993; Mccarthy and Cramb, 2009; Choenkwan et al., 2014). For instance in Bungo district of Jambi province (Fig. 1.2), an undulation area previously dominated by primary forest, secondary forest, and "jungle rubber" (Gouyon et al., 1993). Since introducing intensive agriculture such oil palm and rubber plantations, the land use has changed dramatically and being dominated these plants (Drescher et al., 2016). Topographic gradient of undulating landscape induce distinction characteristic (e.g. soil properties) between upland and valley bottom site (Manning et al., 2001; Solon et al., 2007). In the valley bottom, top soil composition consist of eroded particle (e.g. Nafees et al., 2008). Soil moisture availability for plants in the valley was observed to be higher than upland site in the low rainfall environment (Yu et al., 2001; Tromp-van Meerveld and McDonnell, 2006). With respect to topographic condition and climate change, Lead et al. (2005) reported an increasing flood events over the last six decades with the highest occurring in Asia. In the lowland of Jambi, the valley bottom with higher proximity to river occurs longer flood duration than areas relatively far from river during higher rainfall periods whiles upland site records no flooded.

Study on the influence of topographic position and flooding condition to plant response (i.e. transpiration) has been done. However, there is lack of information on oil palm and rubber plantation in tropical lowland region. Concerning upland to wetland condition, sap flux measurements have been applied to evaluate tree and stand transpiration on site condition variability in North-America (Loranty et al., 2008; Mackay et al., 2010; Angstmann et al., 2012). In Japan, Kume et al. (2015) found higher sap flux and stand transpiration in Japanese cepress (Chamaecyparis obtusa) at valley than upland site, whereas similarity was found for Japanese cedar (Cryptomeria japonica) at both locations (Kumagai et al., 2008). Rare literature on tropical regions exist with example being the study of water table influence on transpiration of certain species in northern Australia and Hawaii (McJannet, 2008; Santiago et al., 2000). These studies reported decreasing transpiration due to waterlogging, whereas some species were found to be adapted to waterlogging condition. Tree species composition has being observed to differ between upland and riparian site in northern Australia. In the riparian sites (with wet until waterlogging 
condition), species may have ability to transpire water during inundation due to adaptation e.g. root system (O'Grady et al., 2006). Contrary to my study site, similar species composition was found across sites and topographic position in oil palm and rubber monoculture plantation. Thus, I focus on the influence of topographic position and flooding condition on water use pattern in oil palm and rubber monoculture.

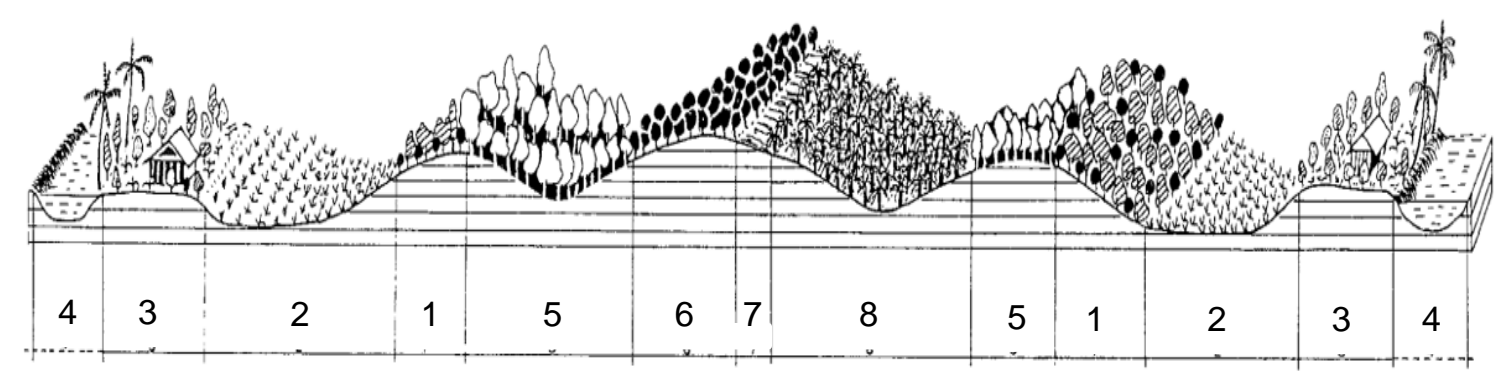

Figure 1.2. Undulating landscape transect between two major rivers in Jambi Province. In the past, the area was characterized by heterogeneous land use, such as: 1 . jungle rubber; 2 . wetland rice and pasture; 3 . Settlement and fruit orchards; 4. River; 5. Logged over forest; 6. Rubber estate plantation (transmigration); 7. Road; and 8. Oil palm state plantation. Recently, oil palm and rubber plantation become the dominant crop in Jambi province (Gouyon et al., 1993; Drescher et al., 2016).

\subsection{Searching "greener" of oil palm and rubber plantation}

Many strategies exist for controlling deforestation and minimizing negative effects of intensive plantation (i.e. oil palm and rubber monoculture) have been proposed (Wilcove and Koh, 2010; Kennedy, 2014). These include regulation, financial, technical and social aspect. There is no best fix strategy which that could be implemented. A mix strategy with government policy, emphasis on market demand and respect to sustainable production has been proposed to give positive results (Wilcove and Koh, 2010). Concerning the sustainable production, cultivated oil palm and rubber in mixed cropping system with native tree species is one potential way (van Noordwijk et al., 2006; Beukema et al., 2007; Ziegler et al., 2009; Villamor et al., 2014; Warren-Thomas et al., 2015; Teuscher et al., 2016).

Since introducing oil palm in Indonesia, smallholder farmers and companies cultivated oil palm through monoculture system (intensive agricultural system). Starting 2013, EFForTS (Ecological and Socioeconomic Functions of Tropical Lowland Rainforest Transformation Systems on Sumatra, Indonesia, www.uni-goettingen.de/efforts, Drescher et al., 2016) project build up oil palm in mixed culture amid native tree 
species that have an economic value such as timber, fruit and latex production. These species includes Parkia speciosa, Durio zibethinus, Archidendron pauciflorum, Peronema canescens, Shorea leprosula and Dyera polyphylla (Teuscher et al., 2016). In an experimental plot, Teuscher et al. (2016) studied biodiversity enrichment with respect to plot size, tree diversity and density. After a year, they found positive correlation between biodiversity enrichment (i.e. bird and invertebrate) and tree planting. On the other hand, for the "greener" rubber product was already established since colonial time in Jambi province by "jungle rubber" cultivation system. However, monoculture system resulted from conversion of jungle rubber as it improved latex productivity since 1950s and now being dominant than jungle rubber (Williams et al., 2001; Feintrenie and Levang, 2009; Drescher et al., 2016).

Subsequently, I focused on rubber tree water partitioning and use in different cultivation system (i.e. rubber monoculture and jungle rubber). I also studied the tree diameter role in water use and partitioning. In rubber monoculture cultivation, a problem in hydrological cycle due to very high evapotranspiration rates have being reported from the Asian mainland by using the eddy covariance method (Tan et al., 2011; Giambelluca et al., 2016). In contrary to that, lower transpiration rates were found in lowlands of Sumatra by thermal dissipation probe (Niu et al., in review). Generally, it is well possible that mixed stands have higher stand transpiration rates (Forrester et al., 2010). Higher water use in mixed stands than monoculture system regarding to tree size and stand density heterogeneity was revealed in Australia (Forrester, 2015). Also in a Panamanian tree plantation, tree diversity increased transpiration (Kunert et al., 2012). Explanations include complementarity in water resource uptake, which e.g. for the stands in Panama have been demonstrated by a stable water isotope $\left(\delta^{18} \mathrm{O}\right.$ and $\left.\delta \mathrm{D}\right)$ approach (Schwendenmann et al., 2015).

On water partitioning, a stable isotopes approach was applied in rubber tree monoculture and mixed cultivation systems study. Cultivation with deep-rooting tree, Flemingia macrophylla, rubber trees took up water closed to soil surface in the rainy season (Wu et al., 2016a). In the dry period, rubber trees took up water from lower layers than the F. macrophylla, thus I assumed competition. A plasticity water uptake depth of rubber tree was indicated by competitive displacement when rubber tree cultivated in intensive agroforestry system (i.e. tea, coffee and cacao) in Southwestern China (Wu et al., 2016b). Furthermore, some researchers provided the influences of tree size on water uptake depth. Meinzer et al. (1999) found the bigger diameter trees took up water from the topsoil and small diameter tress from deeper 
layers in dry tropical forest. Similar finding were also provided in a temperate mixed forest (Meißner et al., 2012) and agroforestry system of South India (Hombegowda, 2015).

\subsection{Objectives and scope of the study}

This study was conducted within collaborative project in the lowland of Jambi province, Indonesia, entitled "Ecological and Socioeconomic Functions of Tropical Lowland Rainforest Transformation Systems on Sumatra, Indonesia (EFForTS)". This project is a multidisciplinary study focusing on ecological and socio-economic framework of transformation system i.e. conversion from rainforest to "jungle rubber", oil palm and rubber monoculture plantation (Drescher et al., 2016). My study contributed on "Tree and oil palm water use characteristics in rainforest transformation systems" (AO2-sub project).

The main focus of this study was on water use and uptake by oil palm and rubber tree regarding topographic position, flooded condition and cultivation systems. Thus I delivered the study through three specific objectives, (1) to determine topographic and flooding influence on oil palm and rubber tree water use pattern, (2) to analyze tree water use and partitioning in monoculture and admixed jungle rubber stands and (3) to ascertain tree diameter role on tree water use and partitioning.

To deliver the objectives, two manuscripts (chapter 3 and 4) are provided in this dissertation. In chapter 3, water use study was developed from previous methods (i.e. Röll, 2015; Niu, 2016) and applied to oil palm and rubber monoculture plantations in Jambi lowland region characterized by undulating topographic and flooding condition. Water use pattern of both plantations were compared between upland and valley bottom sites. For the flooded influence, flooding in the valley bottom was classified into three conditions such as long-term, short-term and no-flooded by visual observation on flooded condition. However, soil water content was measured continuously when no flood occurred in the plot by time domain reflectometer (TDR). I defined long-term flooded duration when waterlogging condition occurred more than 22 days in the valley bottom plot, whereas the plot with not more than 5 days waterlogging was categorized short-term flooded. Non-flooded plot category was classified by no-waterlogging during sap flux measurement. 
Chapter 4 focused on water use and water uptake of rubber trees in different cultivation systems on total eight plots of rubber monoculture and jungle rubber. For each plot, six rubber trees and eight trees (i.e. four rubber trees and four admixed native trees species) were studied in rubber monoculture and admixed jungle rubber stands, respectively. The selected trees belonged to the dominant or co-dominant vertical strata; and abundant native tree species were respected in the jungle rubber. However, $58 \%$ of the rubber trees and $56 \%$ of the admixed native trees were identical between water use and uptake studies. In the water use scheming, data from sunny days were considered due to minimizing climate influence. For the water isotope $\left(\delta^{18} \mathrm{O}\right.$ and $\left.\delta D\right)$ study, soil and stem samples were collected during dry period. However during dry period in 2013 , rainfall intensity was high in Jambi province. Thus, I conducted water isotopes sampling 9 days after rain event on average and I did not include one plot of native tree samples (HJ4, EFForTS nomenclature) in calculation due to rain occurrence during sampling.

\subsection{Outline and author contribution}

This dissertation consists of five chapters. The first chapter provide general introduction, second chapter explains study site and methodology, and the third and fourth chapters being the main findings presented on manuscript at "submitted" and "advance draft" stages of publication process. The last chapter is synthesis.

The author contribution in both manuscripts provided in Chapter 3 and 4, namely:

Chapter 3:

\section{Oil palm and rubber tree water use patterns: effects of topography and flooding}

Afik Hardanto *, Alexander Röll, Furong Niu, Ana Meijide, Hendrayanto, Dirk Hölscher Manuscript status: Accepted on 15 March 2017 in Frontiers in Plant Science, section Agroecology and Land Use Systems, doi: 10.3389/fpls.2017.00452).

* Corresponding author

The concept was developed by Dirk Hölscher based on previous methods (i.e. Röll, 2015; Niu, 2016) within the framework of "EFForTS" project in the lowland Sumatra. The author conducted instrument installation and maintenance of six plot pairs studies regarding topographic position (i.e. upland and valley bottom) and flooding conditions. The author mainly contributed on data collection, data analysis and manuscript preparation including figures, tables and manuscript writing. 


\section{Chapter 4:}

Tree soil water uptake and transpiration in mono-cultural and jungle rubber stands of Sumatra

Afik Hardanto ${ }^{\dagger}$, Alexander Röll ${ }^{\star}{ }^{\dagger}$, Hendrayanto, Dirk Hölscher

Manuscript status: advanced draft

* Corresponding author; ${ }^{\dagger}$ Equal contribution

The concept was developed by Dirk Hölscher within the framework of "EFForTS" project in the lowland Sumatra, in close cooperation with Hendrayanto. The author collected water isotopes $\left(\delta^{18} \mathrm{O}\right.$ und $\left.\delta \mathrm{D}\right)$ samples and in close cooperation with Alex Röll to set up and maintenance sap flux measurement in eight plots (rubber monoculture and jungle rubber). The author contributed on data collection, data analysis and manuscript preparation including figures, tables and manuscript writing.

Two other manuscripts which the author contributes as a co-author and part of "EFForTS" project have been published; one manuscript is in preparation stage. 


\section{References}

Abood, S. A., Lee, J. S. H., Burivalova, Z., Garcia-Ulloa, J., and Koh, L. P. (2015). Relative contributions of the logging, fiber, oil palm and mining industries to forest loss in Indonesia: deforestation among Indonesia's industries. Conserv. Lett. 8, 58-67. doi: 10.1111/conl.12103

Angelsen, A. (1995). Shifting cultivation and 'deforestation': A study from Sumatra, Indonesia. Chr. Michelsen Institute Working paper. Available online at: http://bora.cmi.no/dspace/handle/10202/353 (Accessed October 20, 2016).

Angstmann, J. L., Ewers, B. E., Barber, J., and Kwon, H. (2012). Testing transpiration controls by quantifying spatial variability along a boreal black spruce forest drainage gradient. Ecohydrol. 6, 783-793. doi: 10.1002/eco.1300

Bahroeny, J. J. (2009). Palm oil as an economic pillar of Indonesia. Jkt. Post. Available online at: http://www.thejakartapost.com/news/2009/12/02/palm-oileconomic-pillar-Indonesia.html (Accessed November 11, 2016).

Beukema, H., Danielsen, F., Vincent, G., Hardiwinoto, S., and van Andel, J. (2007). Plant and bird diversity in rubber agroforests in the lowlands of Sumatra, Indonesia. Agrofor. Syst. 70, 217-242. doi: 10.1007/s10457-007-9037-x

Bruijnzeel, L. A. (2004). Hydrological functions of tropical forests: Not seeing the soil for the trees? Agric. Ecosyst. Environ. 104, 185-228. doi:10.1016/j.agee.2004.01.015

Choenkwan, S., Fox, J. M., and Rambo, A. T. (2014). Agriculture in the Mountains of northeastern Thailand: Current situation and prospects for development. Mt. Res. Dev. 34, 95-106. doi: 10.1659/MRD-JOURNAL-D-13-00121.1

Clough, Y., Krishna, V. V., Corre, M. D., Darras, K., Denmead, L. H., Meijide, A., et al. (2016). Land-use choices follow profitability at the expense of ecological functions in Indonesian smallholder landscapes. Nat. Commun. 7:13137. doi:10.1038/ncomms13137

Corley, R. H. V. (2009). How much palm oil do we need?. Environ. Sci. Policy 12, 134-139. doi: 10.1016/j.envsci.2008.10.011

de Guenni, L. B., Cardoso, M., and Ebi, K. (2005). "Regulation of natural hazards: floods and fires," in Ecosystems and Human Well-Being: Current State and Trends, eds. R. Hassan, R. Scholes, N. Ash (Washington, DC: Island Press), 441-454.

DeFries, R. S., Rudel, T., Uriarte, M., and Hansen, M. (2010). Deforestation driven by urban population growth and agricultural trade in the twenty-first century. Nat. Geosci. 3, 178-181. doi: 10.1038/ngeo756

Drescher, J., Rembold, K., Allen, K., Beckschäfer, P., Buchori, D., Clough, Y., et al. (2016). Ecological and socio-economic functions across tropical land use systems after rainforest conversion. Phil. Trans. R. Soc. B. 371:20150275. doi:10.1098/rstb.2015.0275

Eltahir, E. A. B, and Bras, R. L. (1994). Precipitation recycling in the Amazon basin. Q. J. R. Meteorol. Soc. 120, 861-880. 
FAO. (2016). FAOSTAT online statistical service: Food and Agriculture Organization of the United Nations (FAO). Available online at: http://faostat.fao.org/ (Accessed April 10, 2016).

Feintrenie, L., Chong, W. K., and Levang, P. (2010). Why do farmers prefer oil palm? Lessons learnt from Bungo district, Indonesia. Small-Scale For. 9, 379-396. doi:10.1007/s11842-010-9122-2

Feintrenie, L., and Levang, P. (2009). Sumatra's rubber agroforests: Advent, rise and fall of a sustainable cropping system. Small-Scale For. 8, 323-335. doi:10.1007/s11842-009-9086-2

Forrester, D. I., Theiveyanathan, S., Collopy, J. J., and Marcar, N. E. (2010). Enhanced water use efficiency in a mixed Eucalyptus globulus and Acacia mearnsii plantation. For. Ecol. Manag. 259, 1761-1770. doi:10.1016/j.foreco.2009.07.036

Forrester, D. I. (2015). Transpiration and water-use efficiency in mixed-species forests versus monocultures: effects of tree size, stand density and season. Tree Physiol. 35, 289-304. doi: 10.1093/treephys/tpv011

Gaveau, D. L. A., Sheil, D., Husnayaen, Salim, M. A., Arjasakusuma, S., Ancrenaz, M., et al. (2016). Rapid conversions and avoided deforestation: examining four decades of industrial plantation expansion in Borneo. Sci. Rep. 6:32017. doi:10.1038/srep32017

Giambelluca, T. W., Mudd, R. G., Liu, W., Ziegler, A. D., Kobayashi, N., Kumagai, T., et al. (2016). Evapotranspiration of rubber (Hevea brasiliensis) cultivated at two plantation sites in Southeast Asia. Water Resour. Res. 52, 660-679. doi:10.1002/2015WR017755

Gibbs, H. K., Ruesch, A. S., Achard, F., Clayton, M. K., Holmgren, P., Ramankutty, N., et al. (2010). Tropical forests were the primary sources of new agricultural land in the 1980s and 1990s. Proc. Natl. Acad. Sci. 107, 16732-16737. doi:10.1073/pnas.0910275107

Gouyon, A., de Foresta, H., and Levang, P. (1993). Does 'jungle rubber' deserve its name? An analysis of rubber agroforestry systems in Southeast Sumatra. Agroforest. Syst. 22, 181-206. doi: 10.1007/BF00705233

Hansen, M. C., Potapov, P. V., Moore, R., Hancher, M., Turubanova, S. A., Tyukavina, A., et al. (2013). High-resolution global maps of 21st-century forest cover change. Science 342, 850-853. doi: 10.1126/science.1244693

Hombegowda, H. C. (2015). Soil carbon under agroforestry systems of Southern India. [dissertation]. [Göttingen, Germany]: Georg-August-Universität Göttingen.

Kennedy, S. (2014). Eco-certification of natural rubber: demand, supply and potential implications of private global environmental governance. Crit. Plan. 21:1. Available online at: https://escholarship.org/uc/item/02d3918r.pdf (Accessed Jula 25, 2016).

Krashevska, V., Klarner, B., Widyastuti, R., Maraun, M., and Scheu, S. (2015). Impact of tropical lowland rainforest conversion into rubber and oil palm plantations on soil microbial communities. Biol. Fertil. Soils 51, 697-705. doi:10.1007/s00374015-1021-4 
Kumagai, T., Tateishi, M., Shimizu, T., and Otsuki, K. (2008). Transpiration and canopy conductance at two slope positions in a Japanese cedar forest watershed. Agric. For. Meteorol. 148, 1444-1455. doi:10.1016/j.agrformet.2008.04.010

Kume, T., Kenji, T., Komatsu, H., Shinohara, Y., Katayama, A., Ide, J., et al. (2015). Differences in sap flux based stand transpiration between upper and lower slope positions in a Japanese cypress plantation watershed: sap flux in upper and lower slope positions. Ecohydrol. 9, 1105-1116. doi: 10.1002/eco.1709

Kunert, N., Schwendenmann, L., Potvin, C., and Hölscher, D. (2012). Tree diversity enhances tree transpiration in a Panamanian forest plantation: tree transpiration in a tropical plantation. J. Appl. Ecol. 49, 135-144. doi: 10.1111/j.13652664.2011.02065.x

Loranty, M. M., Mackay, D. S., Ewers, B. E., Adelman, J. D., and Kruger, E. L. (2008). Environmental drivers of spatial variation in whole-tree transpiration in an aspen-dominated upland-to-wetland forest gradient. Water Resour. Res. 44, 115. doi: 10.1029/2007WR006272

Mackay, D. S., Ewers, B. E., Loranty, M. M., and Kruger, E. L. (2010). On the representativeness of plot size and location for scaling transpiration from trees to a stand. Biogeosciences 115:G2. doi: 10.1029/2009JG001092

Manning, G., Fuller, L. G., Eilers, R. G., and Florinsky, I. (2001). Topographic influence on the variability of soil properties within an undulating manitoba landscape. Can. J. Soil Sci. 81, 439-447. doi: 10.4141/S00-057

Margono, B. A., Potapov, P. V., Turubanova, S., Stolle, F., and Hansen, M. C. (2014). Primary forest cover loss in Indonesia over 2000-2012. Nat. Clim. Change 4, 730-735. doi: 10.1038/nclimate2277

Mccarthy, J. F., and Cramb, R. A. (2009). Policy narratives, landholder engagement, and oil palm expansion on the Malaysian and Indonesian frontiers. Geogr. J. 175, 112-123. doi: 10.1111/j.1475-4959.2009.00322.x

McJannet, D. (2008). Water table and transpiration dynamics in a seasonally inundated Melaleuca quinquenervia forest, North Queensland, Australia. Hydrol. Process. 22, 3079-3090. doi: 10.1002/hyp.6894

Meinzer, F. C., Andrade, J. L., Goldstein, G., Holbrook, N. M., Cavelier, J., and Wright, S. J. (1999). Partitioning of soil water among canopy trees in a seasonally dry tropical forest. Oecologia 121, 293-301. doi:10.1007/s004420050931

Meißner, M., Köhler, M., Schwendenmann, L., and Hölscher, D. (2012). Partitioning of soil water among canopy trees during a soil desiccation period in a temperate mixed forest. Biogeosciences 9, 3465-3474. doi: 10.5194/bg-9-3465-2012

Mercer, E., and Aruna, P. (2000). Assessing the impacts of forests on human welfare: preliminary results from the Mid-atlantic integrated assessment. Environ. Monit. Assess. 63, 43-63. doi: 10.1023/A:1006453217170 
Merten, J., Röll, A., Guillaume, T., Meijide, A., Tarigan, S., Agusta, H., et al. (2016). Water scarcity and oil palm expansion: social views and environmental processes. Ecol. Soc. 21:5. doi: 10.5751/ES-08214-210205

Mittermeier, R. A., Myers, N., Thomsen, J. B., Da Fonseca, G. A. B., and Olivieri, S. (1998). Biodiversity hotspots and major tropical wilderness areas: approaches to setting conservation priorities. Conserv. Biol. 12, 516-520. doi:10.1046/j.1523-1739.1998.012003516.x

Myers, N., Mittermeier, R. A., Mittermeier, C. G., Da Fonseca, G. A. B., and Kent, J. (2000). Biodiversity hotspots for conservation priorities. Nature 403:6772, 853858. doi: $10.1038 / 35002501$

Nafees, M., Jan, M. R., Khan, H., and Ali, A. (2008). Status of soil texture and required associated soil conservation measure of river swat catchments area, NWFP, Pakistan. Sarhad J. Agric. 24, 251-259.

Niu, F. (2016). Transpiration by oil palm and rubber plantations: refining methods and delineating differences. [dissertation] [Göttingen, Germany]: Georg-AugustGöttingen. Available online at:https://ediss.uni-goettingen.de/handle/11858/001735-0000-002B-7C2C-3 (Acessed November 25, 2016).

O'Grady, A. P., Eamus, D., Cook, P. G., and Lamontagne, S. (2006). Comparative water use by the riparian trees Melaleuca argentea and Corymbia bella in the wet-dry tropics of northern Australia. Tree Physiol. 26, 219-228. doi:10.1093/treephys/26.2.219

Research and Markets. (2016). Indonesia's rubber industry analysis 2016. Available online at: http://www.researchandmarkets.com/research/3mkchv/indonesias. (Accessed November 8, 2016).

Saatchi, S. S., Harris, N. L., Brown, S., Lefsky, M., Mitchard, E. T. A., Salas, W., et al., (2011). Benchmark map of forest carbon stocks in tropical regions across three continents. Proc. Natl. Acad. Sci. 108, 9899-9904. doi:10.1073/pnas.1019576108

Santiago, L. S., Goldstein, G., Meinzer, F. C., Fownes, J. H., and Mueller-Dombois, D. (2000). Transpiration and forest structure in relation to soil waterlogging in a Hawaiian montane cloud forest. Tree Physiol. 20, 673-681. doi:10.1093/treephys/20.10.673

Schwendenmann, L., Pendall, E., Sanchez-Bragado, R., Kunert, N., and Hölscher, D. (2015). Tree water uptake in a tropical plantation varying in tree diversity: interspecific differences, seasonal shifts and complementarity. Ecohydrol. 8, 112. doi: $10.1002 /$ eco.1479

Solon, J., Degórski, M., and Roo-Zielińska, E. (2007). Vegetation response to a topographical-soil gradient. Catena 71, 309-320. doi:10.1016/j.catena.2007.01.006

Tan, Z. H., Zhang, Y. P., Song, Q. H., Liu, W. J., Deng, X. B., Tang, J. W., et al. (2011). Rubber plantations act as water pumps in tropical China: rubber plantation act as water pumps. Geophys. Res. Lett. 38:24. doi:10.1029/2011GL050006 
Teuscher, M., Gérard, A., Brose, U., Buchori, D., Clough, Y., Ehbrecht, M., et al. (2016). Experimental biodiversity enrichment in oil-palm-dominated landscapes in Indonesia. Front. Plant Sci. 7:1538. doi: 10.3389/fpls.2016.01538

Tromp-van Meerveld, H. J., and McDonnell, J. J. (2006). On the interrelations between topography, soil depth, soil moisture, transpiration rates and species distribution at the hillslope scale. Adv. Water Resour. 29, 293-310. doi:10.1016/j.advwatres.2005.02.016

van der Laan, C., Wicke, B., Verweij, P. A., and Faaij, A. P. C. (2016). Mitigation of unwanted direct and indirect land-use change-an integrated approach illustrated for palm oil, pulpwood, rubber and rice production in North and East Kalimantan, Indonesia. GCB Bioenergy. doi:10.1111/gcbb.12353

van Noordwijk, M., Pfund, J. L., Bakarr, M., Jackson, L., Schroth, G., Hairiah, K., et al. (2006). Agro-biodiversity and 14igar tree and forest science: approaches and examples from Sumatra. ICRAF Working Paper. Available online at: http://www.worldagroforestry.org/sea/Publications/files/workingpaper/WP007606.PDF (Accessed November 28, 2016).

Villamor, G. B., Le, Q. B., Djanibekov, U., van Noordwijk, M., and Vlek, P. L. G. (2014). Biodiversity in rubber agroforests, carbon emissions, and rural livelihoods: an agent-based model of land-use dynamics in lowland Sumatra. Environ. Model. Softw. 61, 151-165. doi:10.1016/j.envsoft.2014.07.013

Warren-Thomas, E., Dolman, P. M., and Edwards, D. P. (2015). Increasing demand for natural rubber necessitates a robust sustainability initiative to mitigate impacts on tropical biodiversity: rubber sustainability and biodiversity. Conserv. Lett. 8, 230-241. doi: 10.1111/conl.12170

Wilcove, D. S., Giam, X., Edwards, D. P., Fisher, B., and Koh, L. P. (2013). Navjot's nightmare revisited: logging, agriculture and biodiversity in Southeast Asia. Trends Ecol. Evol. 28, 531-540. doi:10.1016/j.tree.2013.04.005

Wilcove, D. S., and Koh, L. P. (2010). Addressing the threats to biodiversity from oilpalm agriculture. Biodivers. Conserv. 19, 999-1007. doi:10.1007/s10531-0099760-X

Williams, S. E., van Noordwijk, M., Penot, E., Healey, J. R., Sinclair, F. L., and Wibawa, G. (2001). On-farm evaluation of the establishment of clonal rubber in multistrata agroforests in Jambi, Indonesia. Agrofor. Syst. 53, 227-237. doi:10.1023/A:1013336822923

Wu, J., Liu, W., and Chen, C. (2016a). Below-ground interspecific competition for water in a rubber agroforestry system may enhance water utilization in plants. Sci. Rep. 6:19502. doi: 10.1038/srep19502

Wu, J., Liu, W., and Chen, C. (2016b). Can intercropping with the world's three major beverage plants help improve the water use of rubber trees? J. Appl. Ecol. 53, 1787-1799. Doi:10.1111/1365-2664.12730

Yu, Z., Carlson, T. N. Barron, E. J., and Schwartz, F. W. (2001). On evaluating the spatial-temporal variation of soil moisture in the Susquehanna River Basin. Water Resour. Res. 37, 1313-1326. doi: 10.1029/2000WR900369

Ziegler, A. D., Fox, J. M., and Xu, J. (2009). The Rubber Juggernaut. Science 324, 1024-1025. doi: 10.1126/science.1173833 
CHAPTER 2

STUDY SITE AND METHODOLOGY 


\section{Chapter 2 Study site and methodology}

\subsection{Overviews}

The study was part of Ecological and socioeconomic function of tropical lowland rainforest transformation systems (EFForTS) project in Jambi province, Indonesia. The EFForTS project established core plots in the two regions of Bukit duabelas and Harapan (Fig. 2.1.). In the past, both regions were dominated by rain forest. Regrettably, factors such as the transmigration program, increasing population and agricultural sector intensification resulted in decreasing rainforest cover. In Jambi province, recent agricultural sector intensification through oil palm and rubber monoculture has led to significant reduction of only $30 \%$ rainforest remaining. Four transformation systems related to oil palm and rubber (i.e. rainforest, jungle rubber, oil palm and rubber plantation) are present in the lowland of Jambi. Multidisciplinary study by EFForTS project regarding these transformation systems was set up in both regions. Forest, jungle rubber, oil palm monoculture and rubber monoculture with four replicates in each region was selected. The climate of the regions are classified as tropical humid, with annual precipitation and average temperature of $2235 \pm 385 \mathrm{~mm}$ and $26.7 \pm 0.2{ }^{\circ} \mathrm{C}$, respectively. The rainy season occur between October until April with peaks in March and December whiles the dry season is between May to September (Drescher et al., 2016).

Our study was conducted in Harapan region characterized by undulating landscape with different periodic flood duration in the valleys. The studied plots were small holder plantations with similar management practices, age and soil type (i.e. loam Acrisol) with distance between plots relatively close (approximately $10 \mathrm{~km}$ ) to ensure similar environmental condition. Thus, minimize the influence of other environmental variables. The following research goals were addressed: First, water use pattern of oil palm and rubber monoculture plantation regarding spatial (topographic position; ridge and valley bottom) and temporal (non-flooded, short-term flooded and long term flooded) variability. Second, water uptake and use in rubber tree within different cultivation systems (i.e. monoculture and admix "jungle" stands with native tree species). Granier's thermal dissipation probe (TDP) was applied in both studies and water isotopes signature $\left(\delta^{18} \mathrm{O}\right.$ and $\left.\delta \mathrm{D}\right)$ as additional method in the second study. For the original Granier's equation in sap flux studies, lab calibration was conducted for TDP sensor in oil palm, rubber tree and native tree species. The following subheadings provide the plot design and variable measurement. 


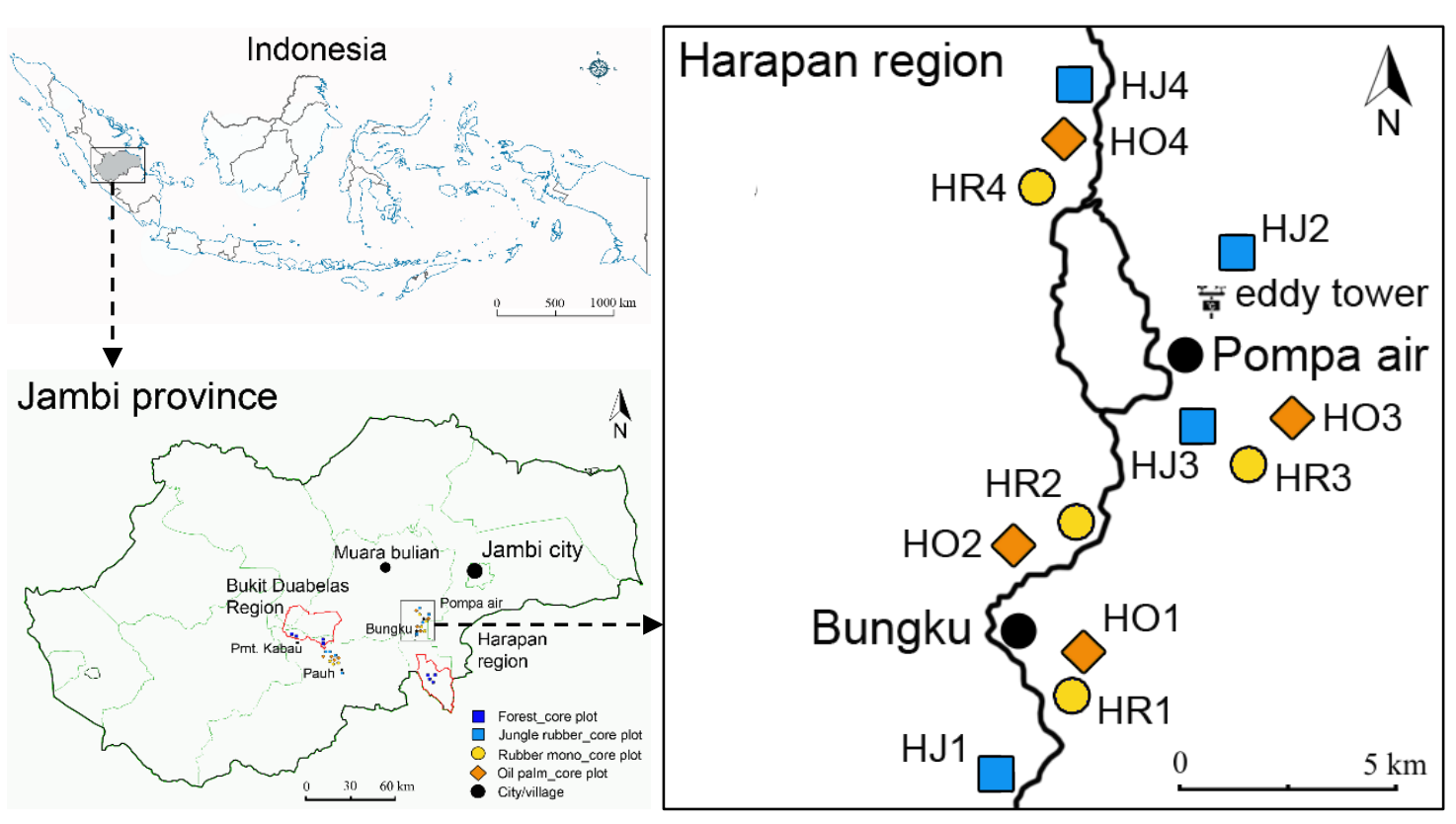

Figure 2.1. Location of EFForTS study sites in Jambi province, Sumatra, Indonesia. The core plot design is located in two landscapes, namely Bukit Duabelas and Harapan region. All the study plot located in Harapan region (Drescher et al., 2016).

\subsection{Studied plot and EFForTS design}

In Harapan region, EFForTS established 16 core plots in the four transformation systems of rainforest, jungle rubber, oil palm and rubber plantation. In each system, four replicates of $50 \times 50 \mathrm{~m}^{2}$ plots were established. Microclimate data on temperature and relative humidity were collected from meteorological stations set up in each plot by ZO2-sub project. Plant species and stand structure characteristic was recorded by the B06- and B04-sub project. Our research focused on three land use types i.e. jungle rubber, oil palm and rubber plantation (Fig. 2.1.). All land use type was cultivated by small holder with similarity on management treatment included fertilization, latex or palm oil harvesting, and trunk epiphytes clearing. The core plots were established in the upland sites with similar altitude $(68.8 \pm 4.7 \mathrm{~m}$. asl, mean \pm se) and age (14 \pm 1.0 years old, oil palm plantation; $15 \pm 0.6$ years old, rubber plantation; and $17 \pm 0.4$ years old, rubber tree in jungle rubber). Significant difference was observed in stem density between oil palm plantation and other land use types. Oil palm stem density was $140 \pm 4.9$ palm ha-1, while higher in rubber plantation (440 \pm 81.7 tree ha-1) and jungle rubber $(525 \pm 60.2$ tree ha- 1$)$. Detail on "EFForTS" design was provided in Drescher et al. (2016) whiles that of experimental design provided in Chapter 3 and 4. 


\subsection{Sap flux density, water use and transpiration}

Granier (1985) thermal dissipation probe (TDP) was applied to measure sap flux density. The sensor consists of a probes pair (i.e. heated and non-heated references probes). We used short $(1.25 \mathrm{~cm})$ and long $(2.5 \mathrm{~cm})$ sensor for oil palm and tree measurement, respectively. Both probes were smeared by heat conductive paste inserted to precise aluminum tube and then into the petiole (oil palm) or stem (tree) with $10 \mathrm{~cm}$ distance between pr-drilled holes. The heated probe was installed in the upper and reference in the lower. The heated probe was connected to a constant power $(250 \mathrm{~mW}, 12 \mathrm{~V})$ and the reference connected to data wire as remain at the prevailing temperature. The sensors were protected by a styrofoam, reflective (aluminum) foil and plastic seal to minimize outer thermal and water influence. The temperature difference between heated and reference probe was measured every 30 seconds, averaged and stored every $10 \mathrm{~min}$ by a CR1000 data logger (Campbell Scientific Inc., Logan, UT, USA). For the details of sampling and water use scheming (i.e. oil palm, rubber tree and native tree species) following Niu et al. (2015) and Röll (2015) are described in Chapter 3 and 4.

\subsection{Water isotopes $\left(\delta^{18} \mathrm{O}\right.$ und $\left.\delta D\right)$ approach}

Soil and xylem samples were collected during dry period or at least six days after raining. Xylem samples were collected from three mixed outer stems (around $5 \mathrm{~cm}$ ) with borer at breast height. The soil samples were augured from three points beneath each of the selected tree at $80 \mathrm{~cm}$ radius around the trunk then pooled with the same soil depth. Soil samples were taken up to $100 \mathrm{~cm}$ depth at the following intervals: 020, 20-40, 40-60, and 60-100 cm. All sampled materials were placed into $40 \mathrm{ml}$ borosilicate glass bottles, sealed with Teflon coated lids, then wrapped in Parafilm and kept frozen (-15 to $-20{ }^{\circ} \mathrm{C}$ ) until water extraction (Ehleringer et al., 2000). Detail sampling on rubber monoculture and jungle rubber are provided in Chapter 4.

Water was extracted from soil and xylem samples by cryogenic vacuum extraction (Ehleringer and Osmond, 1989). Extraction time curves were established to determine the minimum time required to obtain unfractionated water samples i.e. 70 and 90 min for soil and xylem respectively (West et al., 2006). Isotopic composition were measured by injecting water into a temperature conversion/elemental analyzer (TC/EA) coupled via a Con-Flo III interface to a Delta $V$ Plus isotope ratio mass spectrometer (Thermo-Electron Cooperation, Bremen, Germany) as described in 
Gehre et al. (2004). All analyses of the extracted water were performed at the Centre for Stable Isotope Research and Analysis (KOSI, Georg-August-University, Göttingen, Germany). To determine relative contribution of soil water uptake depth to the plant water as a Bayesian framework, the Stable Isotopes analysis in R (SIAR package, R version 3.0.2) was applied (Parnell et al., 2010).

\subsection{Soil moisture and meteorological measurements}

Time domain reflectometry (TDR, CS616, Campbell Scientific, UK) was used to measure soil water content. In each plot, eight TDRs were installed with two replicate at each depth. Within each plot horizontal 1 and $2 \mathrm{~m}$ distance from the palm and tree; each point was installed vertically at two depths (i.e. 0-30 and 30-60 cm). Data were recorded every 30 second, averaged and stored hourly by a data logger (CR1000, Campbell Scientific, UK). Due to limiting precision of equipment performance (Campbell Scientific, 2002), flooded condition was observed visually. In addition, soil moisture sensors (Trime-Pico 32, IMKO) were installed by ZO2-sub project in the center of the EFForTS core plots at a depth of $0.3 \mathrm{~m}$ into the soil; data were recorded hourly by a data logger (LogTrans 16-GPRS, UIT).

Meteorological data was provided by AO3-sub project. In our analysis, we used the closest meteorological station in Pompa Air which was in open terrain at maximum distance of approx. $10 \mathrm{~km}$ from studied plot (Fig. 2.1). Air temperature $\left(\mathrm{T},{ }^{\circ} \mathrm{C}\right)$ and relative humidity $(\mathrm{RH}, \%)$ were measured above canopy by thermohygrometers (type 1.1025.55.000, Thies Clima, Germany). Vapour pressure deficit (VPD, kPa) calculated as the difference between saturation $\left(e_{s}\right)$ and actual $\left(e_{a}\right)$ vapor pressure in given period derived from $\mathrm{T}$ and $\mathrm{RH}$ values (see Allen et al., 1998). Global radiation $\left(R_{\mathrm{g}}, \mathrm{MJ} \mathrm{m}^{-2} \mathrm{~h}^{-1}\right)$ was measured using a CMP3 pyranometer (Kipp \& Zonen, Delf, the Netherlands). All the data measured every 15 seconds and averaged value as 10 minutes were stored on data logger (type DL16 Pro, Thies Clima, Germany). 


\section{References}

Allen, R. G., Pereira, L. S., Raes, D., and Smith, M. (1998). "Meteorological data," in Crop Evapotranspiration: Guidelines for Computing Crop Water Requirements. (Rome: $\quad$ FAO), 29-64. Available online at: http://www.fao.org/docrep/X0490E/X0490E00.htm (Accessed November 23, 2016).

Campbell Scientific, Inc. (2002). Instruction manual: CS616 and CS625 water content reflectometers. Available online at: https://www.campbellsci.com/cs616reflectomer (Accessed December 28, 2016).

Drescher, J., Rembold, K., Allen, K., Beckschäfer, P., Buchori, D., Clough, Y., et al. (2016). Ecological and socio-economic functions across tropical land use systems after rainforest conversion. Philos. Trans. R. Soc. B Biol. Sci. 371:20150275. doi: 10.1098/rstb.2015.0275

Ehleringer, J. R., and Osmond, C. B. (1989). "Stable isotopes," in Plant Physiological Ecology Field Methods and Instrumentation, eds. R.W. Percy, J.R. Ehleringer, H.A. Mooney and P.R. Rundel (London: Chapman and Hall Ltd), 281-300.

Ehleringer, J. R., Roden, J. S., and Dawson, T. E. (2000). "Assessing ecosystemlevel water relations through stable isotope ratio analyses," in Methods in Ecosystem Science, eds. O.E. Sala, R.B. Jackson, H.A. Mooney and R.W. Howarth (New York: Springer-Verlag), 181-198.

Gehre, M., Geilmann, H. Richter, J. Werner, R. A., and Brand, W. A. (2004). Continuous flow $2 \mathrm{H} / 1 \mathrm{H}$ and $18 \mathrm{O} / 16 \mathrm{O}$ analysis of water samples with dual inlet precision. Rapid Commun. Mass Spectrom. 18, 2650-2660. doi:10.1002/rcm.1672

Granier, A. (1985). Une nouvelle méthode pour la mesure du flux de sève brute dans le tronc des arbres. Ann. For. Sci. 42, 193-200. doi: 10.1051/forest:19850204

Niu, F., Röll, A., Hardanto, A., Meijide, A., Köhler, M., Hendrayanto, and Hölscher, D. (2015). Oil palm water use: calibration of a sap flux method and a field measurement scheme. Tree Physiol. 35, 563-573. doi: 10.1093/treephys/tpv013

Parnell, A. C., Inger, R., Bearhop, S., and Jackson, A. L. (2010). Source partitioning using stable isotopes: coping with too much variation. PLOS ONE 5:e9672. doi:10.1371/journal.pone.0009672

Röll, A. (2015). Changes in eco-hydrological functioning after tropical rainforest transformation to rubber and oil palm plantations. [Dissertation]. [Göttingen, Germany]. Available online at: https://ediss.uni-goettingen.de/handle/11858/001735-0000-0023-9641-F (Accessed July 26, 2016).

West, J. B., Bowen, G. J., Cerling, T. E., and Ehleringer, J. R. (2006). Stable isotopes as one of nature's ecological recorders. Trends Ecol. Evol. 21, 408-414. doi:10.1016/j.tree.2006.04.002 
CHAPTER 3

OIL PALM AND RUBBER TREE WATER USE PATTERNS:

EFFECTS OF TOPOGRAPHY AND FLOODING 
Chapter 3 Oil palm and rubber tree water use patterns: effects of topography and flooding

(Accepted on 15 March 2017 in Frontiers in Plant Science, section Agroecology and Land Use Systems, doi: 10.3389/fpls.2017.00452)

Afik Hardanto ${ }^{1,2 *}$, Alexander Röll ${ }^{1}$, Furong Niu ${ }^{1}$, Ana Meijide ${ }^{3}$, Hendrayanto ${ }^{4}$, Dirk Hölscher ${ }^{1}$

${ }^{1}$ University of Goettingen, Tropical Silviculture and Forest Ecology, Germany

${ }^{2}$ Faculty of Agriculture, Jenderal Soedirman University, Indonesia

${ }^{3}$ University of Goettingen, Bioclimatology, Germany

${ }^{4}$ Faculty of Forestry, Bogor Agricultural University, Indonesia 


\section{A B S T R A C T}

Oil palm and rubber plantations extend over large areas and encompass heterogeneous site conditions. In periods of high rainfall, plants in valleys and at riparian sites are more prone to flooding than plants at elevated topographic positions. We asked to what extent topographic position and flooding affect oil palm and rubber tree water use patterns and thereby influence spatial and temporal heterogeneity of transpiration. In an undulating terrain in the lowlands of Jambi, Indonesia, plantations of the two species were studied in plot pairs consisting of upland and adjacent valley plots. All upland plots were non-flooded, whereas the corresponding valley plots included non-flooded, long-term flooded, and short-term flooded conditions. Within each plot pair, sap flux densities in palms or trees were monitored simultaneously with thermal dissipation probes. In plot pairs with nonflooded valleys, sap flux densities of oil palms were only slightly different between the topographic positions, whereas sap flux densities of rubber trees were higher in the valley than at the according upland site. In pairs with long-term flooded valleys, sap flux densities in valleys were lower than at upland plots for both species, but the reduction was far less pronounced in oil palms than in rubber trees $(-22$ and $-45 \%$ in maximum sap flux density, respectively). At these long-term flooded valley plots palm and tree water use also responded less sensitively to fluctuations in micrometeorological variables than at upland plots. In short-term flooded valley plots, sap flux densities of oil palm were hardly affected by flooding, but sap flux densities of rubber trees were reduced considerably. Topographic position and flooding thus affected water use patterns in both oil palms and rubber trees, but the changes in rubber trees were much more pronounced: compared to non-flooded upland sites, the different flooding conditions at valley sites amplified the observed heterogeneity of plot mean water use by a factor of 2.4 in oil palm and by a factor of 4.2 in rubber plantations. Such strong differences between species as well as the pronounced heterogeneity of water use across space and time may be of relevance for ecohydrological assessments of tropical plantation landscapes.

Keywords: heterogeneity; Indonesia; sap flux; Sumatra; transpiration; variability 


\subsection{Introduction}

Oil palm (Elaeis guineensis Jacq.) and rubber (Hevea brasiliensis Müll. Arg.) plantations cover large areas in tropical regions (FAO, 2016) and are projected to expand further (Fox et al., 2012; Van der Laan et al., 2016). In contrast, the area covered by natural forests has strongly declined over the last decades (Keenan et al., 2015). From environmental perspectives, this raises concerns not only with respect to biodiversity (Barnes et al., 2014) but also regarding the integrity of the hydrological cycle including potential changes in transpiration (Ziegler et al., 2009; Sterling et al., 2012).

In previous studies, oil palm transpiration rates were analyzed on 15 on-farm plots in maritime Indonesia using a sap flux technique in conjunction with eddy covariance measurements at two sites (Röll et al., 2015; Meijide et al., under review). Oil palm water use and transpiration increased from young to about 8-year-old plantations and then leveled off up to an age of 22 years (Röll et al., 2015). Among medium-aged, 10-18 years old plantations substantial spatial heterogeneity was found. The highest oil palm stand (evapo) transpiration rates were observed in an intensively managed plantation; they were as high as those of rainforests in the same region (Röll et al., 2015; Meijide et al., 2017). It was also indicated that the temporal dynamics of transpiration in oil palm are "buffered," which means that day-to-day transpiration rates fluctuate less than micrometeorological drivers (Röll et al., 2015). For rubber plantations, previous studies reported relatively high evapotranspiration rates (i.e., partly higher than in adjacent natural forests) from China, Thailand, and Cambodia by means of eddy covariance measurements (Tan et al., 2011; Giambelluca et al., 2016). At the site in Cambodia, an experimental farm, both sap flux (Kobayashi et al., 2014) and eddy covariance measurements (Giambelluca et al., 2016) indicated that rubber tree transpiration responds sensitively to dynamics in radiation, air humidity and soil moisture.

In South East Asia and particularly Indonesia, oil palm and rubber plantations extend over large areas and thus commonly encompass heterogeneous sites. Vast parts of the Southeast Asian lowlands are actually not flat but undulating, separating into upland and valley sites (Miettinen et al., 2014). This leads to differences in soil moisture regimes: when rainfall is low, soil moisture availability for plants will be 
higher at valley sites (Sauer et al., 2005; Tromp-van Meerveld and McDonnell, 2006). Under prevailing high rainfall, plants in valleys and at riparian sites are often flooded for diffrent durations, whereas plants at higher elevations on uplands sites are less prone to flooding (Deo et al., 2015).

In North-America, upland-to-wetland gradients were analyzed by means of sap flux measurements in order to evaluate the significance of site conditions for tree and stand transpiration (Loranty et al., 2008; Mackay et al., 2010; Angstmann et al., 2012). Pronounced differences in tree transpiration were observed among sites and it was concluded that it is necessary to include plots at different topographic positions for landscape level analyses or modeling of transpiration. Sap flux density and stand transpiration of Japanese cypress (Chamaecyparis obtusa) were significantly higher at valley than at upland sites (Kume et al., 2015), while being similar at both locations for Japanese cedar (Cryptomeria japonica) (Kumagai et al., 2008). For tropical rainforest regions such studies are still rare, but the influence of the water table on certain species was analyzed in northern Australia (McJannet, 2008) and Hawaii (Santiago et al., 2000). It was reported that waterlogging reduces transpiration of some species, while other species can adapt to this condition and were thus not or less affected. In tropical rainforests, tree species composition often differs between upland and periodically wet or riparian sites. Species on periodically wet or riparian sites (e.g., Melaleuca argentea W. Fitzg. and Corymbia bella Hill) may have the ability to transpire at high rates even during inundation due to adaptations, e.g., in the root system (O'Grady et al., 2006). In contrast, there is no difference in species composition across sites and topographic positions in monoculture plantations such as rubber and oil palm.

To our knowledge, whether, and if so to what extent landscape position and flooding induce spatial heterogeneity and temporal variability in transpiration rates of oil palms and rubber trees is so far unknown. Our study was implemented in the lowlands of Jambi province on Sumatra, Indonesia. The region is characterized by a steadily undulating topography (Gouyon et al., 1993; Whitten et al., 2000). Only a few decades ago, the region was largely covered by rainforests; today, it is dominated by oil palm and rubber plantations (Laumonier et al., 2010; Margono et al., 2012). Our objective was to determine to what extent topographic position and flooding affect oil palm and rubber tree water use patterns and thereby influence spatial and temporal heterogeneity of transpiration. The study may thus contribute to an improved ecohydrological assessment of post-forest plantations landscapes in tropical lowlands. 


\subsection{Methods}

\subsubsection{Study region}

The study was carried out close to the equator in the "Harapan region" of the lowlands of Jambi Province, Sumatra, Indonesia (Figure 3.1). Annual precipitation averages $2235 \mathrm{~mm}$ and average temperature is $26.7^{\circ} \mathrm{C}$ (Drescher et al., 2016). The terrain is undulating with altitudes varying between 40 and 100 masl at relatively short distance (Figure 3.1).

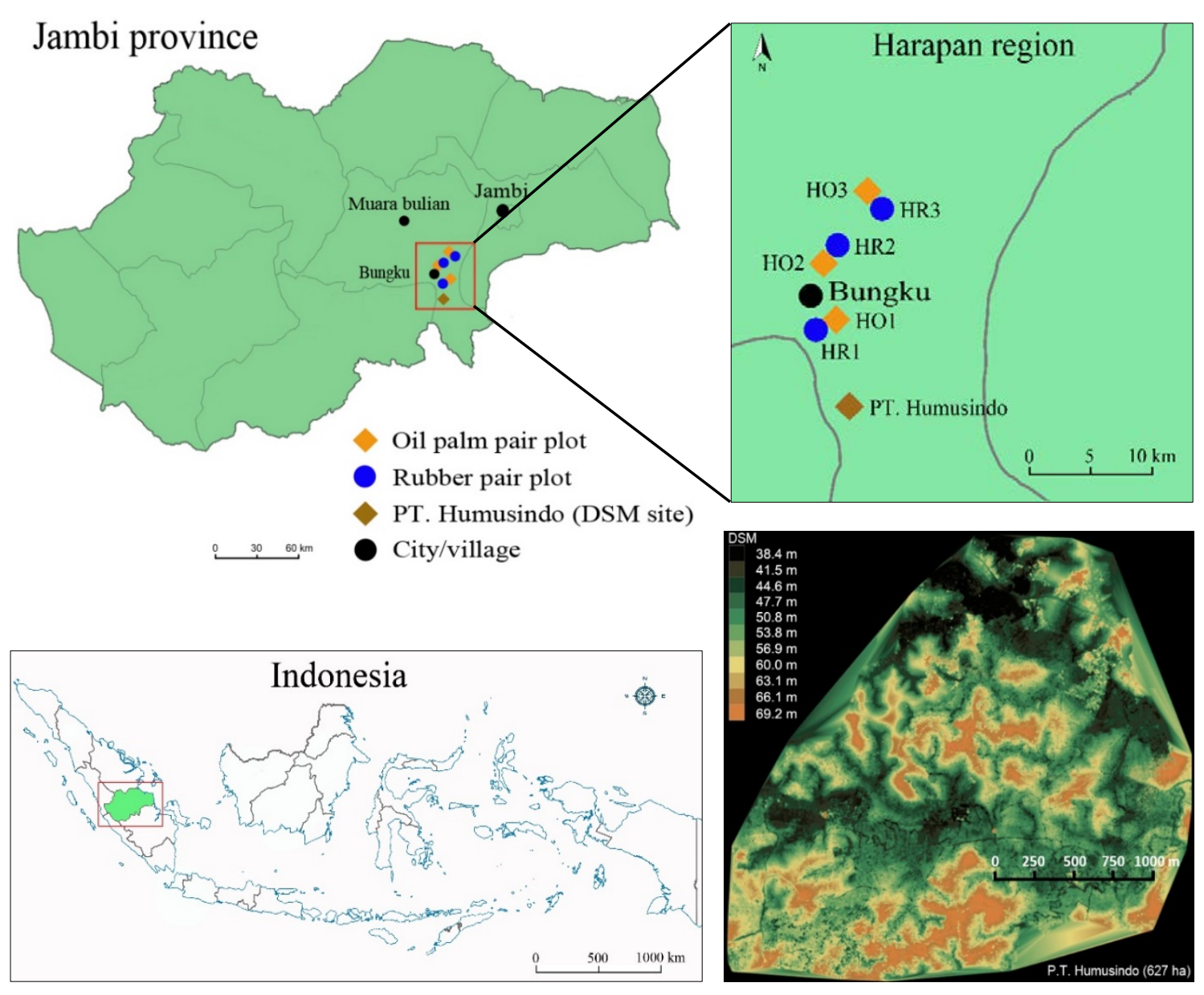

Figure 3.1. The study region ('Harapan region') in Jambi province, Sumatra, Indonesia. Location of oil palm and rubber plot pairs (each consisting of upland and valley sites). Upland sites were part of the larger experimental design of the EFForTS project (Drescher at al. 2016) and had plot codes H (for Harapan) with O for oil palm and $\mathrm{R}$ for rubber; numbering goes from South to North. The terrain of the landscape is undulating, as to be seen on a digital surface model (DSM, Naumann, 2015) of a 627 ha region in an oil palm plantation owned by PT. Humusindo, approximately 10 $\mathrm{km}$ south of our study region (indicated by brown rhombus). 


\subsubsection{Study sites}

Our study comprised 12 plots in six plot pairs. For each plantation type, oil palm or rubber, we studied three plot pairs. Within each pair, one plot was situated at an upland site and the other at an adjacent valley site (Figure 3.2). The upland and valley sites were not more than $50 \mathrm{~m}$ apart. The upland plots were part of the general experimental design of the EFForTS project (Drescher et al., 2016; nomenclature: $\mathrm{HO} 1, \mathrm{HO} 2, \mathrm{HO} 3$ and HR1, HR2, HR3, where $\mathrm{H}$ stands for Harapan region, $\mathrm{O}$ for oil palm and R for rubber); the soil type at upland plots is loam Acrisol (Drescher et al., 2016). Valley sites have alluvial soils formed by accumulating eroded uphill soils. During the entire study period the upland plots were never flooded. During 4-week measurement periods, the valley plots ranged from non-flooded over short-term flooded (4-5 days) to long-term flooded (>22 days, Table 3.1). The plantations were between 14 and 18 years old. Stand densities tended to be higher at the upland sites, whereas diameters were similar between the corresponding upland and valley plots (Table 3.1). The plantations were owned and managed by local smallholders who, within a given plantation type, applied similar cultivation practices across sites.
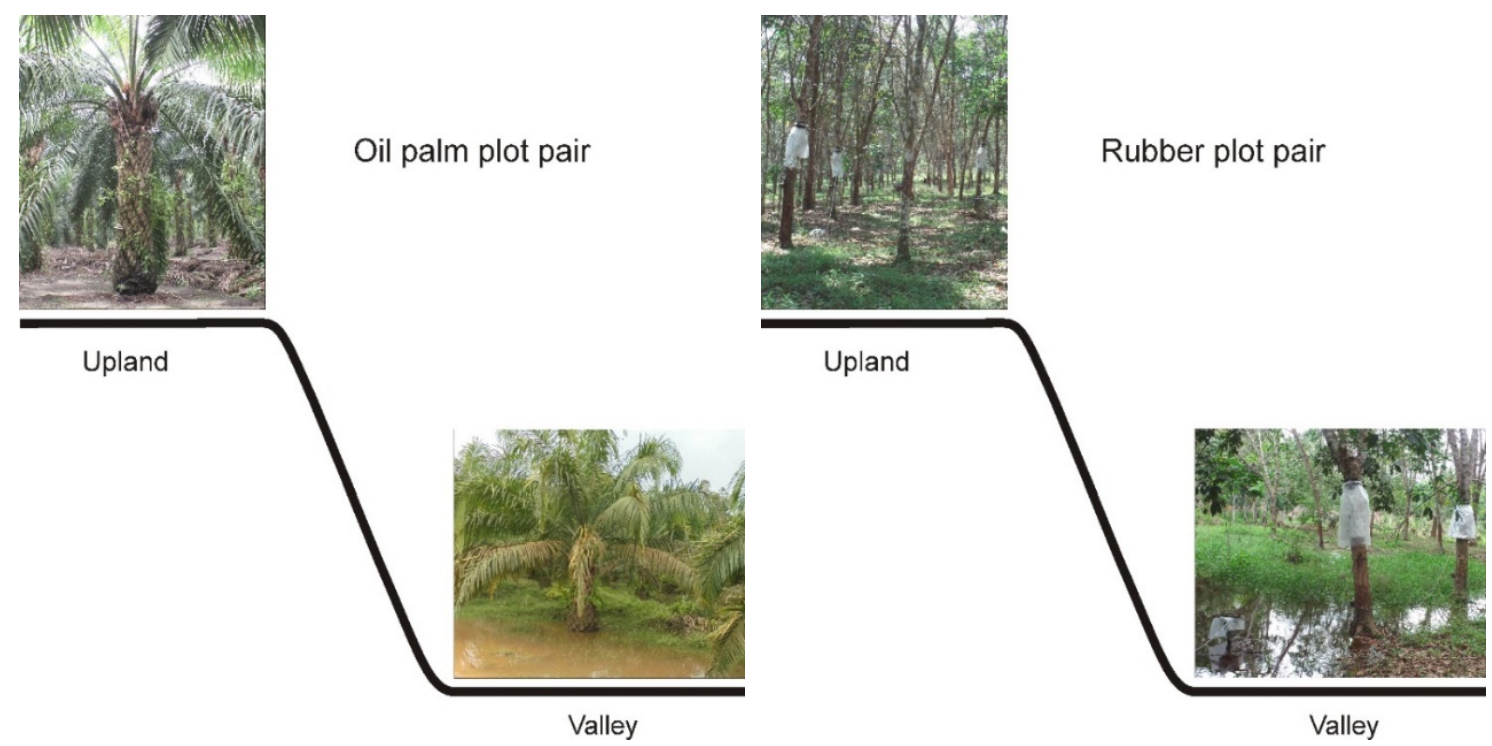

Figure 3.2. In oil palm and rubber plantations, plot pairs consisting of upland and adjacent valley sites were studied, with three replicates for each plantation type. In the study period, the upland plots were never flooded, whereas the valley plots comprised non-flooded, long-term flooded, and short-term flooded conditions. Within each plot pair, sap flux measurements were conducted simultaneously at the upland and according valley site. 
Table 3.1. Stand characteristics and moisture conditions at the different topographic positions in oil palm and rubber plantations.

\begin{tabular}{|c|c|c|c|c|c|}
\hline & \multicolumn{3}{|c|}{ Oil palm plantation } & \multicolumn{2}{|c|}{ Rubber plantation } \\
\hline & \multicolumn{2}{|c|}{ Upland } & Valley & Upland & Valley \\
\hline Age (years) & \multicolumn{2}{|c|}{$16 \pm 1.5$} & $16 \pm 1.5$ & $15 \pm 1.5$ & $15 \pm 1.5$ \\
\hline Density (trees ha ${ }^{-1}$ ) & \multicolumn{2}{|c|}{$144 \pm 6.9$} & $132 \pm 2.6$ & $380 \pm 55.4$ & $354 \pm 103.6$ \\
\hline Diameter (cm) & \multicolumn{2}{|c|}{$80.1 \pm 4.0$} & $77.6 \pm 3.0$ & $22.8 \pm 3.8$ & $24.5 \pm 3.1$ \\
\hline Sap wood area $\left(\mathrm{cm}^{-2}\right)^{a}$ & \multicolumn{2}{|c|}{$25.3 \pm 1.7$} & $22.1 \pm 0.9$ & $181.6 \pm 10.0$ & $219.5 \pm 6.1$ \\
\hline Number of leaves & \multicolumn{2}{|l|}{$34 \pm 2$} & $38 \pm 3$ & - & - \\
\hline Height (m) & \multicolumn{2}{|c|}{$5.7 \pm 1.6$} & $5.6 \pm 0.9$ & $14.4 \pm 0.2$ & $15.0 \pm 0.5$ \\
\hline $\begin{array}{l}\text { Soil moisture (\%), non- } \\
\text { flooded }^{\text {b }}\end{array}$ & \multicolumn{2}{|c|}{$26.2 \pm 4.4$} & $38.1 \pm 1.2$ & $32.8 \pm 2.3$ & $37.8 \pm 3.7$ \\
\hline \multirow[t]{3}{*}{ Flooded (days) } & $\mathrm{HO} 2$ & 0 & 0 & HR2 & 0 \\
\hline & HO1 & 0 & 4 & HR3 0 & 5 \\
\hline & HO3 & 0 & 30 & HR1 0 & 22 \\
\hline \multicolumn{6}{|c|}{$\begin{array}{l}\text { Means and standard errors, } n=3 \text {. } \\
\text { a Sap wood area of oil palm (average per leaf) and rubber trees (average per stem). }\end{array}$} \\
\hline
\end{tabular}

\subsubsection{Sap flux measurements and transpiration}

For each plot pair, sap flux densities $\left(J_{s}, \mathrm{~g} \mathrm{~cm}^{-2} \mathrm{~h}^{-1}\right)$ were measured simultaneously at upland and valley plots with Granier-type thermal dissipation probes (TDP, Granier, 1985) for at least 4 weeks. For oil palm, we followed the sampling and data processing procedure as described in Niu et al. (2015). Four oil palms, each with four sensors inserted into individual leaf petioles, were equipped with TDPs. Specific calibration parameters were applied to calculate $J_{s}$ (Niu et al., 2015) and leaf conductive areas $\left(\mathrm{cm}^{2}\right)$ were determined from a linear regression with petiole baseline length (Niu et al., 2015). To calculate palm water use rates (WU, $\mathrm{kg} \mathrm{day}^{-1}$ ), respective sap flux densities were multiplied by average leaf conductive areas and by the average number of leaves per palm. Multiplying the resulting average palm water use by the number of palms per unit of land yielded stand transpiration rates $(T ; \mathrm{mm}$ day $^{-1}$ ). All 16 TDP sensors of a certain oil palm plot running simultaneously would result in an error margin of estimated stand transpiration of oil palms of about $10 \%$ (Niu et al., 2015). This error is due to a limited sample size for both, establishing the average water conductive area per palm (by counting leaves and measuring petiole 
baseline length on a limited number of palms) and establishing average $J_{s}$ (with a limited number of TDP sensors running simultaneously). Stand transpiration as the product of stand water conductive area and $J_{s}$ reflects both of these errors.

For rubber trees, TDP sensors were installed on six trees per plot with two sensors per tree. The sensors were inserted above the latex harvesting area at a height of about 2-2.5 m. J $J_{s}$ was calculated using the original Granier (1985) equation, which was confirmed in a calibration experiment (Niu et al., under review). Recently established radial $J_{s}$ profiles accounting for changes in $J_{s}$ patterns with increasing xylem depth in rubber trees were applied (Niu et al., under review) to calculate tree water use $\left(\mathrm{kg} \mathrm{day}^{-1}\right)$. Using inventory data from the EFForTS project (stand density and tree diameters, Kotowska et al., 2015), stand transpiration rates could be calculated for the upland sites (see Niu et al., under review, for details); at adjacent valley sites, tree diameter and tree distance were recorded with a measurement tape. According to Kume et al. (2010) potential estimation errors in stand transpiration rates stem from both, a limited sample size (i.e., number of sensors) for establishing the average water conductive area and for establishing average $J_{s}$. For our rubber field measurement scheme, i.e., 12 sensors running simultaneously on six trees error margins of average $J_{s}$ have been reported to be about $10 \%$ (Kobayashi et al., 2014).

\subsubsection{Soil water content}

Soil water content was measured with time domain reflectometry (TDR) sensors (CS616, Campbell Scientific, UK). We installed eight TDRs per plot at two trees or palms, at 1 and $2 \mathrm{~m}$ distance from the trunk, and at two depths $(0-30$ and 30-60 cm). Data were recorded hourly by a data logger (CR1000, Campbell Scientific, UK). Flooding was observed visually.

\subsubsection{Micrometeorological variables}

Micrometeorological variables were monitored at a station about $10 \mathrm{~km}$ distant from our study plots in open terrain. Air temperature and humidity were measured by thermohygrometers (type 1.1025.55.000, Thies Clima, Germany) and were used to calculate vapor pressure deficit (VPD, kPa). Global radiation $\left(R g, \mathrm{MJ} \mathrm{m}^{-2} \mathrm{~h}^{-1}\right)$ was measured using a CMP3 pyranometer (Kipp \& Zonen, Delf, Netherlands). Measurements were taken every $15 \mathrm{~s}$ and averaged and stored as $10 \mathrm{~min}$ values on a data logger (type DL16 Pro, Thies Clima, Germany). 


\subsubsection{Data analysis}

Even though 4-week data series of transpiration were available for each plot pair, results are presented mainly for selected sunny days (radiation $>17 \mathrm{MJ} \mathrm{m}^{-2}$ day $^{-1}$; VPD daytime average $>1.1 \mathrm{kPa}$ ) only. In the case of the short-term flooded plots, naturally only a few days of data were available under flooded conditions; to make these comparable to non-flooded or long-term flooded valley sites, we thus chose to focus on a sunny day only, in order to reduce influences of varying weather conditions among the different measurement periods. For plot pairs with non-flooded or longterm flooded valley sites, for which longer data series were available, the mean values of three sunny days were used to increase the robustness of the results. As most plot pairs were measured successively rather than simultaneously and thus potentially encompassed greatly varying weather conditions, using sunny days helped to focus the analysis on the spatial heterogeneity of (stand) transpiration as induced by flooding, rather than on the temporal day-to-day dynamics of transpiration.

Results are presented both as daily values and as diurnal hourly means; as a measure of the spatial, within-plot variability of $J_{s}$ and stand transpiration, standard errors (SE) of these values are provided; they were derived among all trees or palms within a certain plot (i.e., from 16 sensors on four oil palms or 12 sensors on six rubber trees, in analogy to Niu et al., 2015). Maximum $J_{s}$ values $\left(J_{\text {smax }}\right)$ were derived from the 90-percentile of hourly $J_{s}$ observations of the selected sunny days. Because of unequal variances, we used Welch's $t$-test to test for significant differences $(P<$ 0.05 ) in $J_{s \max }$ and average tree/palm water use within plot pairs, i.e., between upland and valley sites. Likewise, we used Welch's $t$-test (applicable for time repeated measurements) to test for differences between flooded and non-flooded conditions at the short-term flooded valley sites.

The day-to-day $J_{s}$ responses to VPD and $R g$ were analyzed with a power function. Statistical analyses were performed with $\mathrm{R}$ version 3.0.2.

\subsection{Results}

In the plot pairs with non-flooded valleys, oil palm $J_{\text {smax }}$ and daily accumulated $J_{s}$ were 4 and 12\% higher in the valley than on the upland plot (Figure 3.3 and Table 3.2). The differences were more pronounced in the rubber plot pair; $J_{s m a x}$ and the daily accumulated $J_{s}$ were 16 and 30\% higher in the valley (Figure 3.3 and Table 3.2). These differences go along with higher soil moisture contents at valley plots (oil palm: 28 vs. $37 \%$; rubber: 30 vs. $40 \%$, Table 3.1). 


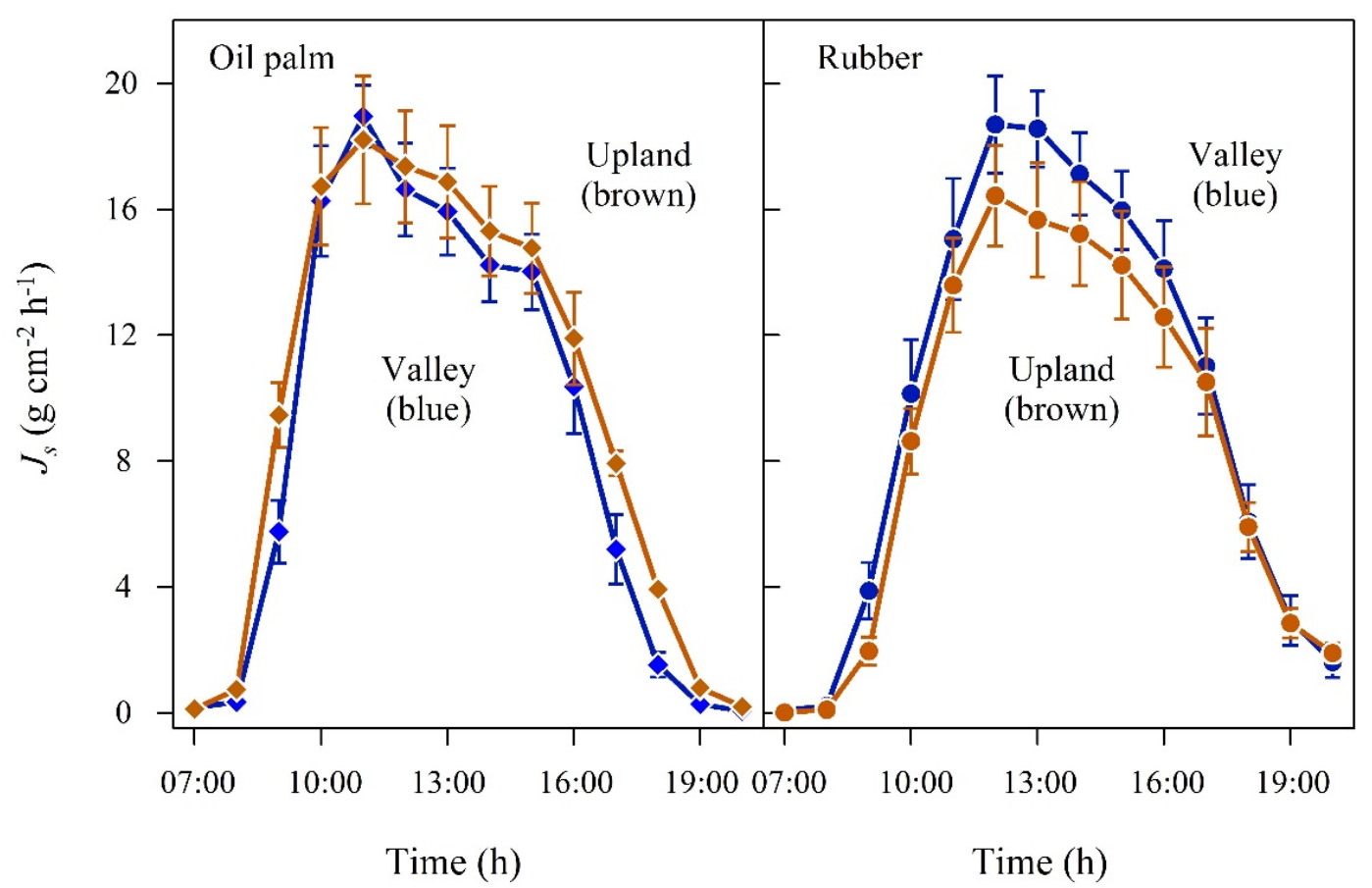

Figure 3.3. Oil palm (left panel) and rubber (right) plot pairs with non-flooded valley. Diurnal course of sap flux density $\left(J_{\mathrm{s}}\right)$ at the upland (brown) and corresponding nonflooded valley site (blue). Hourly means of three sunny days; vertical bars show the standard error of the mean in sap flux among rubber trees $(n=6$ trees; each with two sensors) and oil palms ( $n=4$ palms; each with four leaves and one sensor per leaf) in a plot at a given time.

In the plot pairs with long-term flooded valleys, oil palm in the valley showed lower $J_{s}$ than at upland plots (Figure 3.4). The $J_{\text {smax }}$ in the valley was by $22 \%$ lower than on the upland plot (Table 3.2). A similar pattern was found in rubber trees, but again the difference was more pronounced $\left(J_{\text {smax }}-45 \%\right)$. Long-term flooding also influenced the day-to-day $J_{s}$ response to changes in VPD and $R g$ : accumulated daily $J_{s}$ generally increased with increasing VPD (Figure 3.5) and Rg (Figure 3.6) for both plantation types and flooding conditions, but the slopes of the regression equations were smaller in valleys than at upland sites, particularly for rubber (Figures 3.5 and 3.6). 


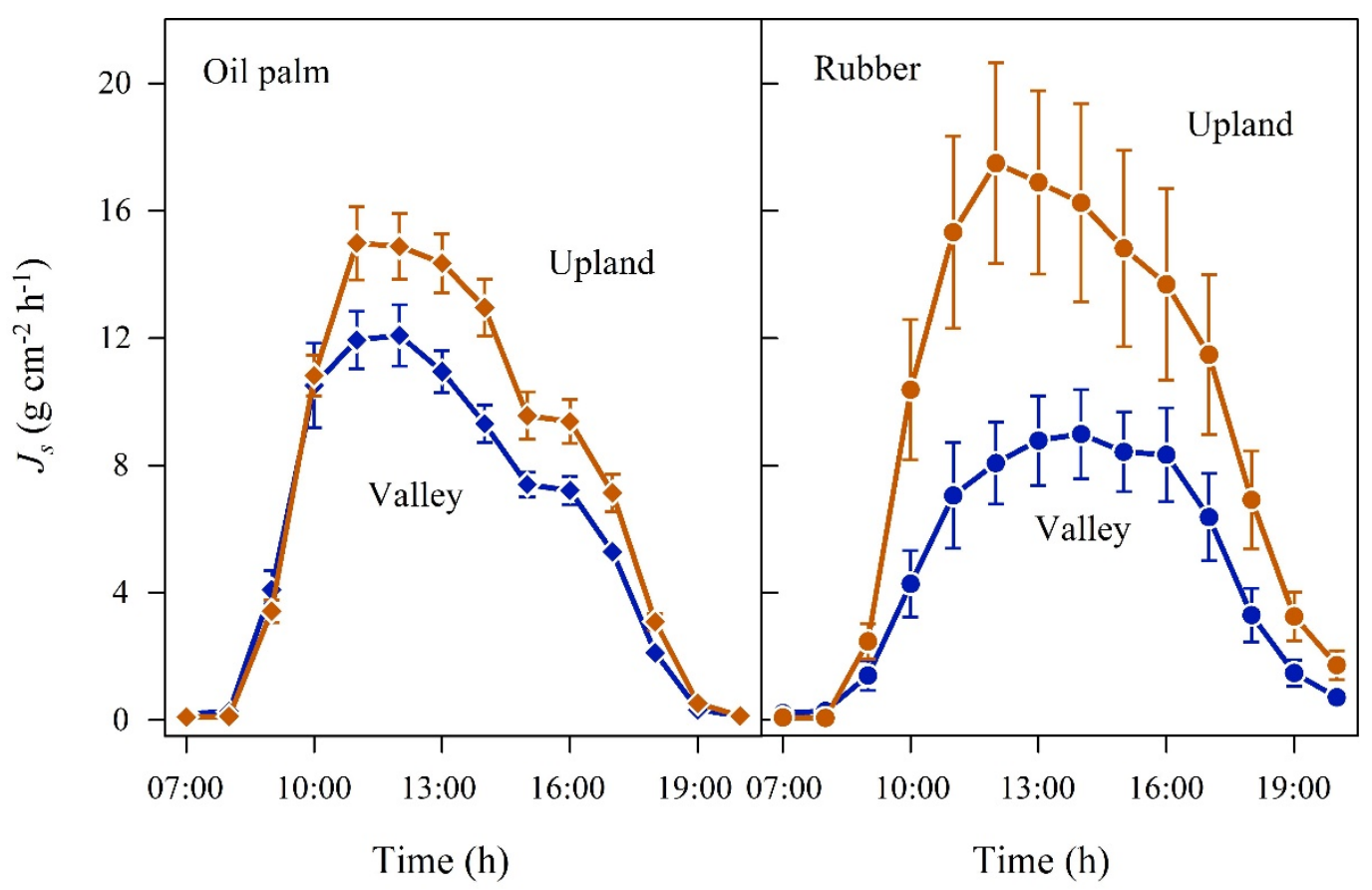

Figure 3.4. Oil palm (left panel) and rubber (right) plot pairs with long-term flooded valley. Diurnal course of sap flux density $\left(J_{s}\right)$ at the upland (brown) and corresponding long-term flooded valley site (blue). Hourly means of three sunny days; vertical bars show the standard error of the mean in sap flux among rubber trees ( $n=6$ trees; each with two sensors) and oil palms ( $n=4$ palms; each with four leaves and one sensor per leaf) in a plot at a given time.

In the plot pair with short-term flooded valley, $J_{s}$ in oil palm hardly responded to flooding (Figure 3.7 and Table 3.2). In contrast, $J_{\text {smax }}$ and daily accumulated $J_{s}$ in rubber were 19 and $22 \%$ lower on a flooded day than on a non-flooded day, indicating a much more sensitive response to short-term flooding in rubber trees than in oil palms.

Overall, topographic position and flooding affected the heterogeneity of rubber tree and oil palm water use differently. The observed range of plot-averaged, normalized oil palm water use was 2.4-fold larger at valley sites than at upland sites, while for rubber trees, it was 4.2-fold larger at valley sites (Figure 3.8 and Table 3.2). Translating these differences from the tree/palm level to patterns of transpiration estimates at the plot scale, i.e., taking into account differences in tree and palm densities and sizes between upland and valley sites, the heterogeneity of transpiration was increased by a factor of 2.3 from the upland to the valley in oil palm and by a factor of 12.5 in rubber plots (Figure 3.8 and Table 3.2). 


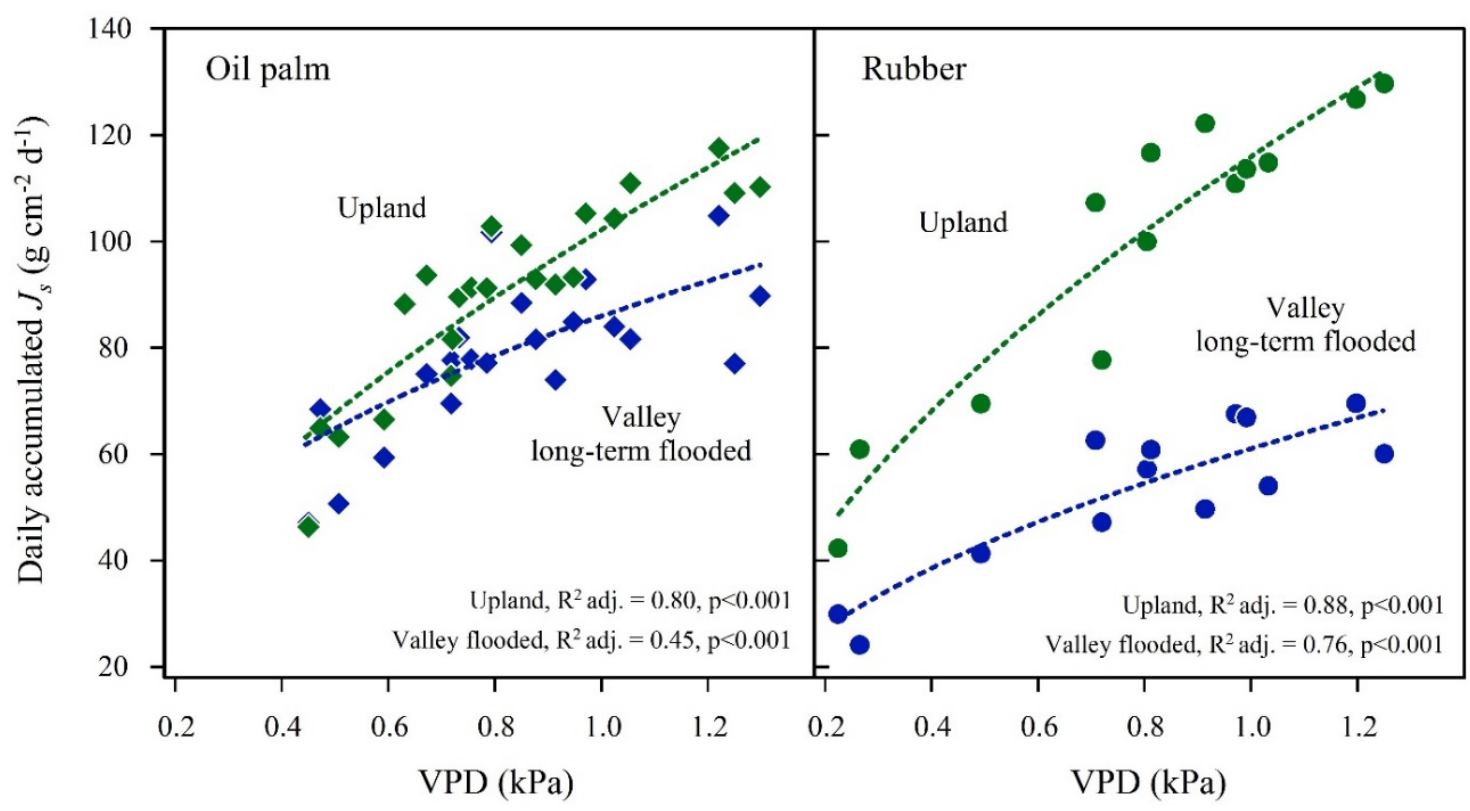

Figure 3.5. Oil palm (left panel) and rubber (right) plot pairs with long-term flooded valley. Daily accumulated sap flux density $\left(J_{s}\right)$ in response to changes in average daily vapor pressure deficit (VPD) at the upland (green) and corresponding long-term flooded valley site (blue). Plot pairs were $\mathrm{HO} 3$ for oil palm and HR1 for rubber.

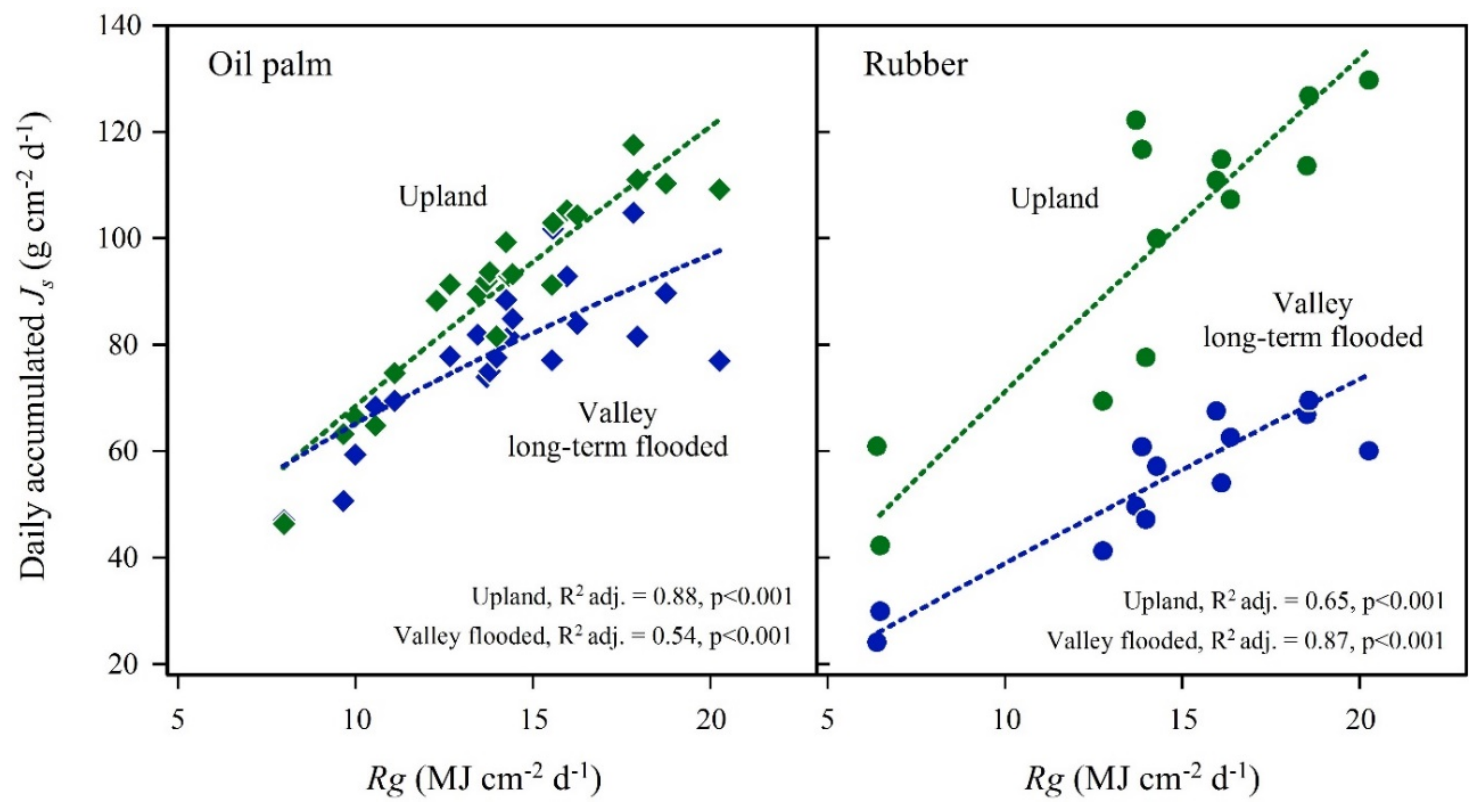

Figure 3.6. Oil palm (left panel) and rubber (right) plot pairs with long-term flooded valley. Daily accumulated sap flux density $\left(J_{s}\right)$ in response to to changes in global radiation daysums $\left(R_{\mathrm{g}}\right)$ at the upland (green) and corresponding long-term flooded valley site (blue). Plot pairs were $\mathrm{HO} 3$ for oil palm and HR1 for rubber. 


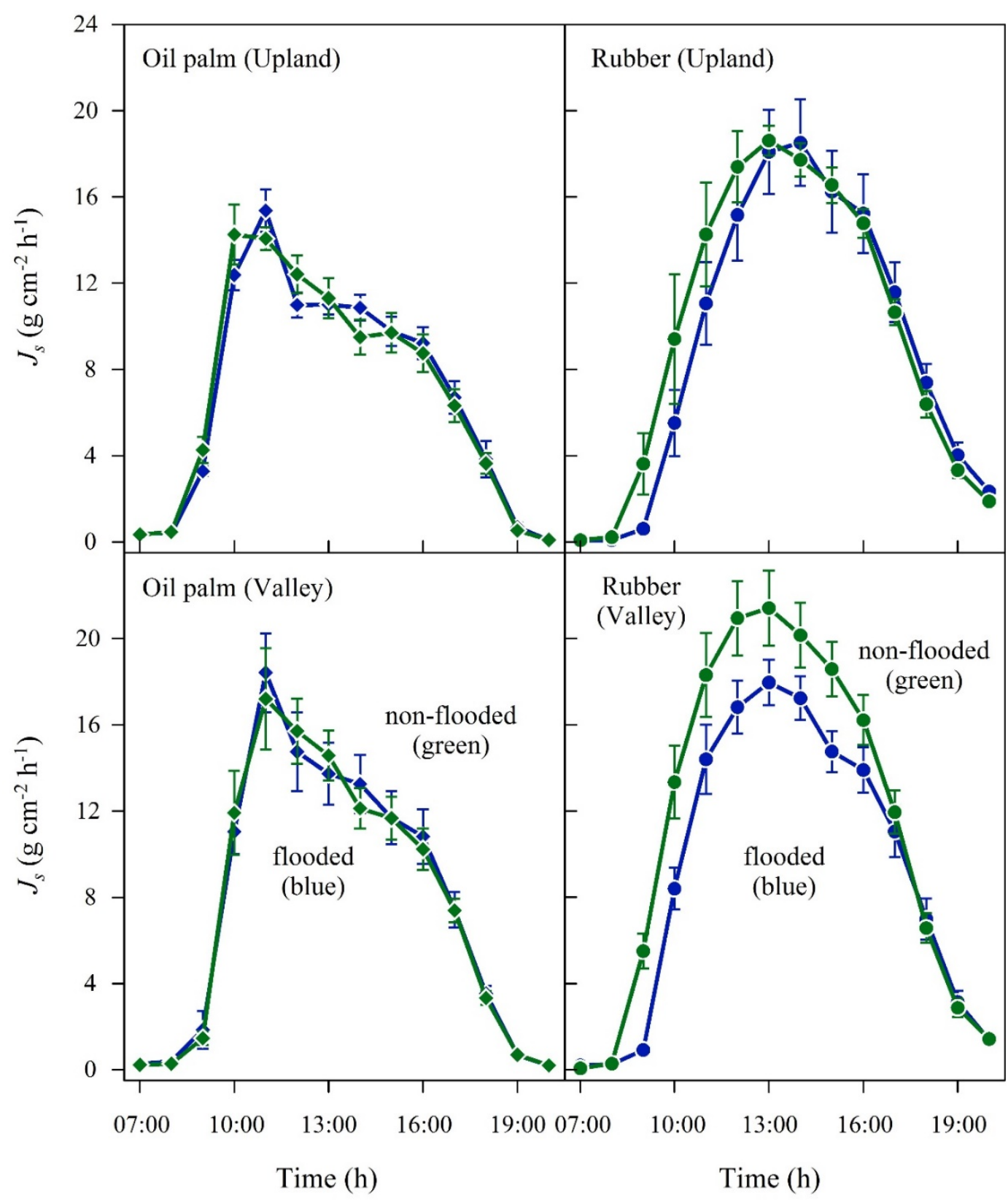

Figure 3.7. Oil palm (left panels) and rubber (right) plot pairs with short-term flooded valley. Flooded and non-flooded conditions at the valley sites are compared. Diurnal course of sap flux density $\left(J_{s}\right)$ at upland (upper panels) and corresponding valley sites (lower). Upland sites were always non-flooded, but valley sites varied between nonflooded (green) and short-term flooded (blue) conditions. For the according periods (i.e. valley non-flooded, valley short-time flooded), upland $J_{s}$ as a reference is displayed separately (in green and blue, respectively). Hourly values on a sunny day; vertical bars show the standard error of the mean in sap flux among rubber trees $(n=$ 6 trees; each with two sensors) and oil palms ( $n=4$ palms; each with four leaves and one sensor per leaf) in a plot at a given time. 


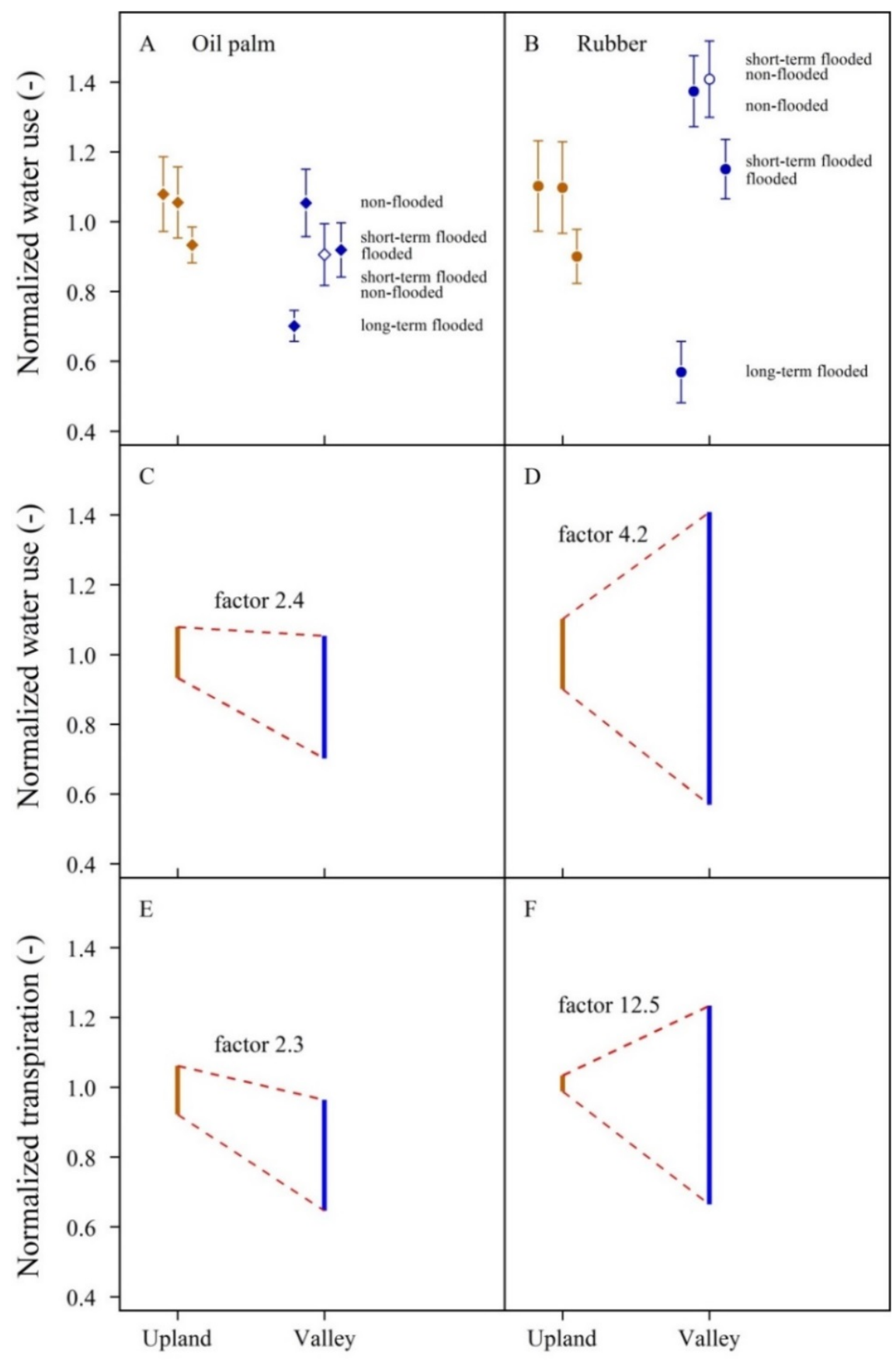

Figure 3.8. Long-term, short-term and non-flooded plot pairs combined. Water use by oil palm and rubber trees across upland and valley plots, normalized by mean oil palm (A) and rubber tree (B) water use on the upland plots (sunny days, means and standard errors). Short term flooded valley plots are given twice, once under flooded (closed symbols) and once under non-flooded (open symbols) conditions. Dynamics of the heterogeneity of normalized water use (C and D) and normalized transpiration ( $E$ and $F$ ) of oil palm and rubber from upland to valley plots. Displayed factors quantify the heterogeneity that is induced as a result of topographic position and flooded conditions at valley sites in relation to the heterogeneity at upland sites. 
Table 3.2. Maximum sap flux density $\left(J_{s m a x}\right)$ in oil palm leaf petioles and rubber tree trunks, water use per palm and tree and estimated stand transpiration rates at upland and valley plots under varying flooding conditions i.e. non-flooded, long-term and short-term flooded (sunny days, means and standard errors).

\begin{tabular}{|c|c|c|c|c|c|c|}
\hline \multirow[b]{2}{*}{ Plot pair } & \multicolumn{3}{|c|}{ Oil palm } & \multicolumn{3}{|c|}{ Rubber } \\
\hline & $\begin{array}{c}J_{\operatorname{smax}} \\
\left(\mathrm{g} \mathrm{cm}^{-2} \mathrm{~h}^{-1}\right)\end{array}$ & $\begin{array}{l}\text { Water use } \\
\qquad\left(\mathrm{kg} \mathrm{d}^{-1}\right)\end{array}$ & $\begin{array}{l}\text { Transpiration } \\
\qquad\left(\mathrm{mm} \mathrm{d}^{-1}\right)\end{array}$ & $\begin{array}{c}J_{s \max } \\
\left(\mathrm{g} \mathrm{cm}^{-2} \mathrm{~h}^{-1}\right)\end{array}$ & $\begin{array}{l}\text { Water use } \\
\qquad\left(\mathrm{kg} \mathrm{d}^{-1}\right)\end{array}$ & $\begin{array}{c}\text { Transpiration } \\
\qquad\left(\mathrm{mm} \mathrm{d}^{-1}\right)\end{array}$ \\
\hline \multicolumn{7}{|l|}{ Valley non flooded } \\
\hline Upland (HO2 and HR2) & $17.1 \pm 0.9$ & $94.8 \pm 4.5$ & 1.3 & $16.7 \pm 0.7$ & $26.6 \pm 3.2$ & 0.9 \\
\hline Valley & $17.7 \pm 0.9^{\mathrm{ns} 1)}$ & $94.7 \pm 4.6^{\mathrm{ns} 1)}$ & 1.2 & $19.3 \pm 0.7^{\mathrm{ns} 1)}$ & $\left.33.2 \pm 2.5^{\star 1} 1\right)$ & 1.2 \\
\hline \multicolumn{7}{|l|}{ Valley long-term flooded } \\
\hline Upland (HO3 and HR1) & $14.8 \pm 0.5$ & $97.0 \pm 5.0$ & 1.4 & $15.3 \pm 1.0$ & $26.5 \pm 3.2$ & 0.9 \\
\hline Valley & $11.6 \pm 0.6^{\star 1)}$ & $63.0 \pm 2.0^{\left.\star^{1}\right)}$ & 0.8 & $8.4 \pm 0.5^{\star \star 1)}$ & $13.8 \pm 2.1^{\star * 1)}$ & 0.6 \\
\hline \multicolumn{7}{|l|}{ Valley short-term flooded } \\
\hline Upland (HO1 and HR3) & $13.6 \pm 0.5$ & $83.9 \pm 2.5$ & 1.2 & $17.8 \pm 0.6$ & $21.8 \pm 1.9$ & 1.0 \\
\hline \multicolumn{7}{|l|}{ Valley } \\
\hline 1. Non-Flooded & $16.1 \pm 0.6^{\mathrm{ns} 2)}$ & $81.3 \pm 3.9^{\mathrm{ns} 2}$ ) & 1.1 & $21.3 \pm 0.9^{\left.\star^{2}\right)}$ & $34.0 \pm 2.6^{\left.\star^{2}\right)}$ & 1.1 \\
\hline 2. Flooded & $16.0 \pm 0.6$ & $82.7 \pm 3.5$ & 1.1 & $17.3 \pm 0.7$ & $27.8 \pm 2.1$ & $\begin{array}{l}1.1 \\
0.7\end{array}$ \\
\hline
\end{tabular}

* indicate significant differences between upland and valley sites ${ }^{1)}$ and between flooded and non-flooded condition at the short-term flooded valley sites ${ }^{2)}$ at ${ }^{*} \mathrm{P}<0.05$ and ${ }^{*} \mathrm{P}<0.01 ; \mathrm{ns}=$ not significant, time repeated $\mathrm{t}$-tests. 


\subsection{Discussion}

In our study, topography and flooding induced substantial heterogeneity in plant water use. This was more pronounced in rubber trees than in oil palms. Our estimates of stand transpiration (0.6-1.2 $\mathrm{mm}$ day $^{-1}$ for rubber, 0.8-1.4 $\mathrm{mm}$ day $^{-1}$ for oil palm) were substantially lower than those reported for rubber plantations on the Asian mainland ( $\sim 2 \mathrm{~mm}$ day $^{-1}$, Isarangkool Na Ayutthaya et al., 2010; Kobayashi et al., 2014; Sopharat et al., 2015) and lower than those reported for an intensively managed oil palm plantation in the study region (2.5-2.7 mm day ${ }^{-1}$; Röll et al., 2015; Meijide et al., 2017). However, our oil palm estimate falls into the range of $1.1-2.5 \mathrm{~mm}$ day $^{-1}$ from a previous study in 12 productive oil palm plantations in the study region (including our three upland oil palm sites, Röll et al., 2015). Likewise, our rubber estimate compares to the mean of five-fully leaved, mature plantations in the study region ( $1.3 \mathrm{~mm}$ day $^{-1}$, Niu et al., under review). Potential reasons for partly relatively large differences between our values and those reported in other studies include differences among methods with respect to the cited rubber studies, as well as different environmental site conditions and differences in management practices such as the utilization of varying clone types. In oil palm, our measurement approach has been calibrated (Niu et al., 2015) and yielded plausible results when compared to eddy covariance data (Röll et al., 2015). For rubber, no eddy covariance data was available for comparison, but conducted laboratory experiments and field assessments with different sap flux techniques showed no contradictions and give confidence that our approach is feasible (Niu et al., under review). Analyses of estimation uncertainties of water use rates due to limited sample size with our respective oil palm and rubber field measurement schemes point to potential uncertainties of mean water use of about 10\% (Kobayashi et al., 2014; Niu et al., 2015). However, and regardless of potential uncertainties in absolute water use rates of rubber trees and oil palms, this study was mainly designed to investigate relative differences in water use patterns between topographic positions and flooding conditions; to accurately quantify such relative differences in patterns is regarded a strength of sap flux approaches.

For both oil palms and rubber trees, $J_{s}$ and plant water use were higher at nonflooded valley sites than at the corresponding upland sites. This was probably caused by more favorable soil moisture contents in valleys (i.e., higher, but not waterlogged, Table 3.1), which are likely due to run-off and drainage from adjacent slopes. In contrast, Js and water use of both plantation types were lower than at upland plots in 
long-term flooded valleys. Floods reduce gaseous oxygen concentrations in soils and thus lead to hypoxic or anoxic conditions (Ezin et al., 2010; Wittmann and Pfanz, 2014). Root hydraulic conductivity nd permeability are severely reduced (Else et al., 2001; Parent et al., 2008; Kreuzwieser and Rennenberg, 2014), which results in changes in leaf water potential, stomatal closure, and lower leafspecific hydraulic conductivity (Else et al., 2001; Atkinson et al., 2008; Herrera, 2013; Zhao et al., 2014). Consequently, plant water uptake is often substantially reduced under flooded conditions (Nicolás et al., 2005; Aroca et al., 2012; Yan et al., 2015). Long-term flooding can furthermore decrease water uptake capacities by injuring roots (Drew, 1997). For a scenario of frequent, long-term flooding, e.g., at riparian or valley sites, damages to the trunk induced by the frequent manual cutting for latex extraction could be enhanced, particularly at the trunk base. This could facilitate the entry of fungi and potentially reduce productivity and vitality of flood-prone rubber trees. However, flood-related mortality of rubber trees was not observed in the study region (personal observation); this is likely due to a combination of the relatively short rotation cycle of monoculture rubber plantations in the study region (approximately 20 years) and adaptions to regular flooding in the natural habitat of rubber (Amazonia). In accordance with the substantial decreases in the water use of oil palms $(-35 \%)$ and rubber trees $(-48 \%)$ under long-term flooded conditions in our study, decreases in water uptake under long-term flooded conditions were also pronounced in studies on other (tropical) species such as apricot ( 15\%), eucalyptus ( 20\%), and lemon ( 50\%) trees (Nicolás et al., 2005; Ortuño et al., 2007; Miyazawa et al., 2014).

Theoretically, lower (stand) transpiration of both plantation types under long-term flooded conditions could also be due to factors other than flooding, e.g., differences in site or stand characteristics. As the flooding periods at the long-term flooded valley sites exceeded the respective sap flux measurement periods, no data are available to evaluate stand transpiration under nonflooded conditions. However, the results from the short-term flooded plots for both oil palm and rubber (Figure 3.7) do not contradict the finding of lower transpiration as a result of long-term flooding. Further, the respective upland and valley sites of each plot pair (and thus including the pairs with long-term flooded valley) were located close to each other ( $<50 \mathrm{~m}$ distance), within the same (small-holder) plantations. Non-flooding related additional factors such as site, stand or management characteristics within plot pairs were thus relatively homogeneous and unlikely to be the dominant factor for low stand transpiration rates at long-term flooded valleys sites. Asides from the substantially reduced water use 
rates, the strong influence of long-term flooding on plant water use in our study is also visible in the less sensitive responses of $J_{s}$ to VPD and radiation (Figures 3.5, 3.6). These micrometeorological drivers were not measured above the canopy of each particular site but rather represent more general, open area upland conditions some kilometers from our sites. However, while variables such as air humidity and wind speed likely vary considerably between upland and valley sites even at short distance, radiation as an important driver of transpiration can be expected to vary far less due to the close proximity of our study sites to the equator. Keeping this in mind, our results indicate a more conservative response to environmental drivers at longterm flooded valley sites for both species, which may be related to reductions in root hydraulic conductivity and stomatal conductance. Substantial decreases in stomatal conductance were, e.g., reported for sweet gum (Liquidambar styraciflua L.), where it decreased by $24 \%$ after 1 day of flooding and by $70 \%$ after 9 days of flooding (Pezeshki and Chambers, 1985).

For all of the topographic positions and flooding conditions evaluated in this study, $J_{S}$ and water use of rubber trees responded more sensitively than $J_{s}$ and water use of oil palms. Varying $J_{S}$ responses to flooded conditions between oil palm and rubber are in line with results from other studies, e.g., strong $J_{s}$ decreases in Eucalyptus camaldulensis, but no noticeable reductions of $J_{s}$ in the Shorea roxburghii and Dipterocarpus obtusifolius (Miyazawa et al., 2014). Likewise, Js was reported to be higher at valley sites than at upland sites for Japanese cypress (Kumagai et al., 2008), while being similar at both locations for Japanese cedar (Kume et al., 2015).

Such differences between species in their water use response to flooding are influenced by differences in plant morphology, particularly of the root and leaf system (Aroca et al., 2012; Kreuzwieser and Rennenberg, 2014; Miyazawa et al., 2014). Oil palm has a fibrous root system and its roots can spread over $6 \mathrm{~m}$ vertically and $25 \mathrm{~m}$ horizontally, while the rubber root system typically extends less (3-13 m) (Jourdan et al., 2000; Gonkhamdee, 2010). On an intra-annual basis, oil palms are not very dynamic in leaf area. The water use response of oil palms at upland sites to environmental drivers, in particular to air humidity, has been described as buffered (Röll et al., 2015). Based on hysteresis between water use and VPD, it was argued that internal stem water storage herein plays a role, as it had previously been observed in other palm species (Holbrook and Sinclair, 1992). In contrast to these attributes of oil palm, rubber trees at upland sites are quite responsive to dynamics of environmental drivers and shed their leaves during dry seasons (Kobayashi et al., 
2014; Giambelluca et al., 2016), both of which enhances the heterogeneity of rubber water use across space and time. Within certain ranges, our findings thus point to and strengthen previous suggestions that oil palm water use is only moderately affected by environmental conditions including floods. In contrast, rubber tree water use is quite responsive to fluctuations in environmental conditions including short- and longterm flooding.

Both rubber and oil palm plantations cover large areas of the Sumatran lowlands, where they have replaced highly diverse natural forests. It, however, seems that the post-forest plantation landscape has more heterogeneous transpiration patterns than one might expect. This heterogeneity can partly be explained by the age class structure of the plantation landscape and by species differences in the response to environmental drivers including periodical leaf shedding in rubber (Röll et al., 2015; Niu et al., under review). As to how far different management schemes also play a role needs to be analyzed in more depth. Patterns described in Röll et al. (2015) suggest that high fertilizer input as mostly found in large estates leads to higher transpiration rates than in less intensively managed smallholder plantations. The present study adds yet another dimension to the plantation landscape by suggesting that topography and flooding are also strong factors influencing the heterogeneity of landscape-level transpiration patterns. Likewise, studies investigating upland-towetland gradients in North-America also found pronounced differences in tree transpiration and it was concluded that it is necessary to include sites at different topographic positions for landscape-level analyses or modeling (Loranty et al., 2008; Mackay et al., 2010; Angstmann et al., 2012). In our case, we found only moderate variation in oil palm water use across space and time, whereas rubber responded strongly to topographic position and temporal flooding. These differences may be of interest in eco-hydrological assessments of post-forest plantation landscapes.

\section{Acknowledgments}

This study was supported by a grant from the German Research Foundation (DFG, CRC 990, A02, Z02 and ABS project). Afik Hardanto received a scholarship from the Indonesian-German Scholarship Programme (IGSP) and Furong Niu received a scholarship from the China Scholarship Council (CSC). We acknowledge support by the Open Access Publication Funds of the University of Goettingen. We would like to thank Heri Junaedi and Andrea Hanf for field support and cooperation, Agusta Herdhata and Surya Tarigan for constructive cooperation, and our field assistants Ali, Bayu and Ferry for supporting us at all times during the field measurements. 


\section{References}

Angstmann, J. L., Ewers, B. E., Barber, J., and Kwon, H. (2012). Testing transpiration controls by quantifying spatial variability along a boreal black spruce forest drainage gradient. Ecohydrol. 6, 783-793. doi: 10.1002/eco.1300

Aroca, R., Porcel, R., and Ruiz-Lozano, J. M. (2012). Regulation of root water uptake under abiotic stress conditions. J. Exp. Bot. 63, 43-57. doi: 10.1093/jxb/err266

Atkinson, C. J., Harrison-Murray, R. S., and Taylor, J. M. (2008). Rapid flood-induced stomatal closure accompanies xylem sap transportation of root-derived acetaldehyde and ethanol in Forsythia. Environ. . Exp. Bot. 64, 196-205. doi:10.1016/j.envexpbot.2008.02.001

Barnes, A. D., Jochum, M., Mumme, S., Haneda, N. F., Farajallah, A., Widarto, T. H., and Brose, U. (2014). Consequences of tropical land use for multitrophic biodiversity and ecosystem functioning. Nat. Commun. 5:5351. doi:10.1038/ncomms6351

Deo, R. C., Byun, H. R., Adamowski, J. F., and Kim, D. W. (2015). A real-time flood monitoring index based on daily effective precipitation and its application to Brisbane and Lockyer valley flood events. Water Resour. Manag. 29, 40754093. doi: 10.1007/s11269-015-1046-3

Drescher, J., Rembold, K., Allen, K., Beckschäfer, P., Buchori, D., Clough, Y., et al. (2016). Ecological and socio-economic functions across tropical land use systems after rainforest conversion. Phil. Trans. R. Soc. B. 371:20150275. doi:10.1098/rstb.2015.0275

Drew, M. C. (1997). Oxygen deficiency and root metabolism: injury and acclimation under hypoxia and anoxia. Annu. Rev. Plant Biol. 48, 223-250. doi:10.1146/annurev.arplant.48.1.223

Else, M. A., Coupland, D., Dutton, L., and Jackson, M. B. (2001). Decreased root hydraulic conductivity reduces leaf water potential, initiates stomatal closure and slows leaf expansion in flooded plants of castor oil (Ricinus communis) despite diminished delivery of ABA from the roots to shoots in xylem sap. Physiol. Plant. 111, 45-64. doi: 10.1034/j.1399-3054.2001.1110107.x

Ezin, V., Pena, R. D. L., and Ahanchede, A. (2010). Flooding tolerance of tomato genotypes during vegetative and reproductive stages. Braz. J. Plant Physiol. 22, 131-142. doi: 10.1590/S1677-04202010000200007

FAO. (2016). FAOSTAT Online Statistical Service: Food and Agriculture Organization of the United Nations (FAO). Available online at: http://faostat.fao.org (Accessed April 10, 2016).

Fox, J., Vogler, J. B., Sen, O. L., Giambelluca, T. W., and Ziegler, A. D. (2012). Simulating land-cover change in Montane mainland Southeast Asia. Environ. Manag. 49, 968-979. doi:10.1007/s00267-012-9828-3

Giambelluca, T. W., Mudd, R. G., Liu, W., Ziegler, A. D., Kobayashi, N., Kumagai, T., et al. (2016). Evapotranspiration of rubber (Hevea brasiliensis) cultivated at two plantation sites in Southeast Asia. Water Resour. Res. 52, 660-679. doi:10.1002/2015WR017755

Gonkhamdee, S. (2010). Analysis of interactions between rubber tree (Hevea brasiliensis Mull. Arg.) and inter-crop roots in young plantations of NE Thailand. [dissertation]. [Avignon (Fr)]: Université d'Avignon. Available online at: https://tel.archives-ouvertes.fr/tel-00504888 (Accessed April 6, 2016). 
Gouyon, A., de Foresta, H., and Levang, P. (1993). Does 'jungle rubber' deserve its name? An analysis of rubber agroforestry systems in Southeast Sumatra. Agroforest. Syst. 22, 181-206. doi: 10.1007/BF00705233

Granier, A. (1985). Une nouvelle méthode pour la mesure du flux de sève brute dans le tronc des arbres. Ann. For. Sci. 42, 193-200. doi: 10.1051/forest:19850204

Herrera, A. (2013). Responses to flooding of plant water relations and leaf gas exchange in tropical tolerant trees of a black-water wetland. Front. Plant Sci. 4:106. doi: 10.3389/fpls.2013.00106

Holbrook, N. M., and Sinclair, T. R. (1992). Water balance in the arborescent palm, Sabal palmetto. II. Transpiration and stem water storage. Plant Cell Environ. 15, 401-409. doi: 10.1111/j.1365-3040.1992.tb00990.x

Isarangkool Na Ayutthaya, S., Do, F. C., Pannengpetch, K., Junjittakarn, J., Maeght, J.-L., Rocheteau, A., et al. (2010). Transient thermal dissipation method of xylem sap flow measurement: multi-species calibration and field evaluation. Tree Physiol. 30, 139-148. doi: 10.1093/treephys/tpp092

Jourdan, C., Ferriere, N. M., and Perbal, G. (2000). Root system architecture and gravitropism in the oil palm. Ann. Bot. 85, 861-868. doi:10.1006/anbo.2000.1148

Keenan, R. J., Reams, G. A., Achard, F., Freitas, J. V., Grainger, A., and Lindquist, E. (2015). Dynamics of global forest area: results from the FAO global forest resources assessment 2015. For. Ecol. Manag. 352, 9-20. doi: 10.1016/j.foreco.2015.06.014

Kobayashi, N., Kumagai, T., Miyazawa, Y., Matsumoto, K., Tateishi, M., Lim, T. K., et al. (2014). Transpiration characteristics of a rubber plantation in central Cambodia. Tree Physiol. 34, 285-301. doi: 10.1093/treephys/tpu009

Kotowska, M. M., Leuschner, C., Triadiati, T., Meriem, S., and Hertel, D. (2015). Quantifying above- and belowground biomass carbon loss with forest conversion in tropical lowlands of Sumatra (Indonesia). Global Change Biol. 21, 3620-3634. doi: 10.1111/gcb.12979

Kreuzwieser, J., and Rennenberg, H. (2014). Molecular and physiological responses of trees to waterlogging stress: responses of tree to waterlogging. Plant Cell Environ. 37, 2245-2259. doi: 10.1111/pce.12310

Kumagai, T., Tateishi, M., Shimizu, T., and Otsuki, K. (2008). Transpiration and canopy conductance at two slope positions in a Japanese cedar forest watershed. Agric. For. Meteorol. 148, 1444-1455. doi: 10.1016/j.agrformet.2008.04.010

Kume, T., Kenji, T., Komatsu, H., Shinohara, Y., Katayama, A., Ide, J., and Otsuki, K. (2015). Differences in sap flux based stand transpiration between upper and lower slope positions in a Japanese cypress plantation watershed: sap flux in upper and lower slope positions. Ecohydrol. 9:6. doi: 10.1002/eco.1709

Kume, T., Tsuruta, K., Komatsu, H., Kumagai, T., Higashi, N., Shinohara, Y., et al. (2010). Effects of sample size on sap flux-based stand-scale transpiration estimates. Tree Physiol. 30, 129-138. doi: 10.1093/treephys/tpp074

Laumonier, Y., Uryu, Y., Stüwe, M., Budiman, A., Setiabudi, B., and Hadian, O. (2010). Eco-floristic sectors and deforestation threats in Sumatra: identifying new conservation area network priorities for ecosystem-based land use planning. Biod. Cons. 19, 1153-1174. doi: 10.1007/s10531-010-9784-2 
Loranty, M. M., Mackay, D. S., Ewers, B. E., Adelman, J. D., and Kruger, E. L. (2008). Environmental drivers of spatial variation in whole-tree transpiration in an aspen-dominated upland-to-wetland forest gradient. Water Resour. Res. 44:W02441. doi: 10.1029/2007WR006272

Mackay, D. S., Ewers, B. E., Loranty, M. M., and Kruger, E. L. (2010). On the representativeness of plot size and location for scaling transpiration from trees to a stand. J. Geophys. Res. 115:G2. doi: 10.1029/2009JG001092

Margono, B. A., Turubanova, S., Zhuravleva, I., Potapov, P., Tyukavina, A., Baccini, A., et al. (2012). Mapping and monitoring deforestation and forest degradation in Sumatra (Indonesia) using Landsat time series data sets from 1990 to 2010. Environ. Res. Lett. 7:3. doi: 10.1088/1748-9326/7/3/034010

McJannet, D. (2008). Water table and transpiration dynamics in a seasonally inundated Melaleuca quinquenervia forest, north Queensland, Australia. Hydrol. Process. 22, 3079-3090. doi: 10.1002/hyp.6894

Meijide, A., Röll, A., Fan, Y., Herbst, M., Niu, F., Tiedemann, F., et al. (2017). Controls of water and energy fluxes in oil palm plantations: environmental variables and oil palm age. Agric. For. Meteorol. 239, 71-85. doi: 10.1016/j. agrformet.2017.02.034

Miettinen, J., Stibig, H. J., and Achard, F. (2014). Remote sensing of forest degradation in Southeast Asia-Aiming for a regional view through 5-30 m satellite data. Global Ecol. Cons. 2, 24-36. doi: 10.1016/j.gecco.2014.07.007

Miyazawa, Y., Tateishi, M., Komatsu, H., Ma, V., Kajisa, T., Sokh, H., Mizoue, N., and Kumagai, T. (2014). Tropical tree water use under seasonal waterlogging and drought in central Cambodia. J. Hydrol. 515, 81-89. doi:10.1016/j.jhydrol.2014.04.049

Naumann, R. V. (2015). Exploration of tropical landscape structures by an unmanned aerial vehicle in Sumatra. [master's thesis]. [Göttingen (Germany)]: GeorgAugust-Universität Göttingen.

Nicolás, E., Torrecillas, A., Amico, J. D., and Alarcón, J. J. (2005). The effect of shortterm flooding on the sap flow, gas exchange and hydraulic conductivity of young apricot trees. Trees 19, 51-57. doi: 10.1007/s00468-004-0362-7

Niu, F., Röll, A., Hardanto, A., Meijide, A., Köhler, M., Hendrayanto, and Hölscher, D. (2015). Oil palm water use: Calibration of a sap flux method and a field measurement scheme. Tree Physiol. 35, 563-573. doi: 10.1093/treephys/tpv013

O'Grady, A. P., Eamus, D., Cook, P. G., and Lamontagne, S. (2006). Comparative water use by the riparian trees Melaleuca argentea and Corymbia bella in the wet-dry tropics of northern Australia. Tree Physiol. 26, 219-228. doi:10.1093/treephys/26.2.219

Ortuño, M. F., Alarcón, J. J., Nicolás, E., and Torrecillas, A. (2007). Water status indicators of lemon trees in response to flooding and recovery. Biol. Plant. 51, 292-296. doi: 10.1007/s10535-007-0058-0

Parent, C., Capelli, N., Berger, A., Crèvecoeur, M., and Dat, J. F. (2008). An overview of plant responses to soil waterlogging. Plant Stress 2, 20-27.

Pezeshki, S. R., and Chambers, J. L. (1985). Stomatal and photosynthetic response of sweet gum (Liquidambar styraciflua) to flooding. Can. J. For. Res. 15, 371375. doi: 10.1139/x85-059 
Röll, A., Niu, F., Meijide, A., Hardanto, A., Hendrayanto, Knohl, A., et al. (2015). Transpiration in an oil palm landscape: Effects of palm age. Biogeosciences 12, 9209-9242. doi: 10.5194/bgd-12-9209-2015

Santiago, L. S., Goldstein, G., Meinzer, F. C., Fownes, J. H., and Mueller-Dombois D. 2000. Transpiration and forest structure in relation to soil waterlogging in a Hawaiian montane cloud forest. Tree Physiol. 20, 673-681. doi:10.1093/treephys/20.10.673

Sauer, T. J., Logsdon, S. D., Brahana, J. V., and Murdoch, J. F. (2005). Variation in infiltration with landscape position: implications for forest productivity and surface water quality. For. Ecol. Manag. 220, 118-127. doi:10.1016/j.foreco.2005.08.009

Sopharat, J., Gay, F., Thaler, P., Sdoodee, S., Isarangkool Na Ayutthaya, S., Tanavud, C., et al. (2015). A simple framework to analyze water constraints on seasonal transpiration in rubber tree (Hevea brasiliensis) plantations. Front. Plant Sci. 5:753. doi: 10.3389/fpls.2014.00753

Sterling, S. M., Ducharne, A., and Polcher, J. (2012). The impact of global land-cover change on the terrestrial water cycle. Nat. Clim. Change 3, 385-390. doi:10.1038/nclimate1690

Tan, Z. H., Zhang, Y. P., Song, Q. H., Liu, W. J., Deng, X. B., Tang, J. W., et al. (2011). Rubber plantations act as water pumps in tropical China. Geophys. Res. Lett. 38:24. doi: 10.1029/2011GL050006

Tromp-van Meerveld, H.J., and McDonnell, J. J. (2006). On the interrelations between topography, soil depth, soil moisture, transpiration rates and species distribution at the hillslope scale. Adv. Water Resour. 29, 293-310. doi:10.1016/j.advwatres.2005.02.016

Van der Laan, C., Wicke, B., Verweij, P. A., and Faaij, A. P. C. (2016). Mitigation of unwanted direct and indirect land-use change-an integrated approach illustrated for palm oil, pulpwood, rubber and rice production in North and East Kalimantan, Indonesia. GCB Bioenergy. doi:10.1111/gcbb.12353

Whitten, T., Damanik, S. J., Anwar, J., and Hisyam, N. (2000). The Ecology of Sumatra. Singapore: Periplus Edition, Ltd.

Wittmann, C., and Pfanz, H. (2014). Bark and woody tissue photosynthesis: a means to avoid hypoxia or anoxia in developing stem tissues. Funct. Plant Biol. 41, 940-953. doi: 10.1071/FP14046

Yan, X. L, Xi, B. Y., Jia, L. M., and Li, G. D. (2015). Response of sap flow to flooding in plantations of irrigated and non-irrigated triploid poplar. J. For. Res. 20, 375385. doi: 10.1007/s10310-015-0485-2

Zhao, H. F., Zhao, Y., Zhang, C., Tao, X., and Xu, X. N. (2014). Growth, leaf gas exchange, and chlorophyll fluorescence responses of two cultivars of Salix integra Thunb. to waterlogging stress. J. Agric. Sci. Tech. 16, 137-146.

Ziegler, A. D., Fox, J. M., and Xu, J. (2009). The rubber juggernaut. Science 324:5930. doi: 10.1126/science.1173833 
CHAPTER 4

TREE SOIL WATER UPTAKE AND TRANSPIRATION IN MONO-

CULTURAL AND JUNGLE RUBBER STANDS

OF SUMATRA 
Chapter 4 Tree soil water uptake and transpiration in mono-cultural and jungle rubber stands of Sumatra

(advanced draft)

Afik Hardanto ${ }^{1,2 \dagger}$, Alexander Röll ${ }^{1^{\star} \dagger}$, Hendrayanto ${ }^{3}$, Dirk Hölscher ${ }^{1}$

${ }^{1}$ University of Goettingen, Tropical Silviculture and Forest Ecology, Germany

${ }^{2}$ Faculty of Agriculture, Jenderal Soedirman University, Indonesia

${ }^{3}$ Faculty of Forestry, Bogor Agricultural University, Indonesia

* Corresponding author: aroell@gwdg.de

${ }^{\dagger}$ Equal contribution 


\section{A B S T R A C T}

Rubber tree mono-cultural plantations are expanding and there is also a search for 'green' rubber production. Rubber tree cultivation in stands with admixed, spontaneously established native trees, referred to as jungle rubber, has a long tradition on Sumatra. For rubber tree monocultures on mainland Asia, concerns have been raised because of potentially very high tree transpiration rates. The objectives of our study were to analyze tree water use rates and tree soil water uptake depths in mono-cultural and jungle rubber stands with a focus on the role of tree diameter. Sap flux measurements suggest similar water use rates for rubber trees in the two cultivation systems. Stand-level transpiration in jungle rubber was $27 \%$ higher than in rubber monocultures, which was related to higher stand densities in jungle rubber stands. A water stable isotope $\left(\delta^{18} \mathrm{O}\right.$ and $\left.\delta \mathrm{D}\right)$ approach suggests different soil water uptake depths for the rubber trees in the two cultivation systems. In a relatively dry period, the main tree water uptake in the monoculture was relatively close to the soil surface, whereas rubber trees in jungle rubber stands mainly took up water from deeper soil strata; here the native trees had their main uptake depth relatively close to the soil surface. This pattern indicates plasticity in rubber tree water uptake and points to competitive displacement. Across rubber trees in both cultivation systems and also among the native trees, there was a clear relationship between tree diameter and soil water uptake depth: bigger trees tended to take up soil water closer to the soil surface. Diameter and density regulation by thinning of big native trees thus appears as a potential management option for influencing water uptake in jungle rubber stands in favor of rubber trees.

Keywords: competition, ecohydrology, Hevea brasiliensis, poly-cultures, resource partitioning, sap flux, stable isotopes 


\subsection{Introduction}

Rubber tree (Hevea brasiliensis Müll. Arg.) plantations are widespread in Asia and there is a tendency towards further expansion (Fox et al., 2012; FAO, 2016). The predominant mono-cultural rubber plantations are however associated with a relatively low biodiversity and shifts in ecosystem services (Warren-Thomas et al., 2015; Hu et al., 2008). One potential way of reconciling environmental and latex production needs could be the cultivation of rubber trees in mixed cropping systems (van Noordwijk et al., 2006, 2012; Beukema et al., 2007; Ziegler et al., 2009; Villamor et al., 2014; Warren-Thomas et al., 2015).

In rubber monoculture cultivation, the integrity of the hydrological cycle may be of concern as very high evapotranspiration rates were reported from the Asian mainland based on eddy covariance measurements (Tan et al., 2011; Giambelluca et al., 2016). In contrast to this, substantially lower transpiration rates were found in smallholder plantations in the Sumatran lowlands based on the application of a sap flux method (Niu et al., in review). Potential influences of differences in methods, management and climate between the studies on Sumatra and the mainland were discussed in this context. The study in Sumatra also pointed to a strong increase of rubber tree water use with increasing tree diameter among relatively young, up to eight year-old plantations (Niu et al., in review). For mixed rubber cultivations systems, we are currently not aware of any published studies on transpiration and tree water use. In general, it is not unlikely that mixed stands have higher stand transpiration rates than monocultures (Forrester et al., 2010). A such, mixed stands of Eucalyptus globulus and Acacia mearnsii in Australia had higher transpiration rates than the respective monocultures; this reflected generally larger tree sizes in mixtures (Forrester, 2015). Likewise, in a Panamanian experimental plantation, increasing tree diversity enhanced stand level transpiration (Kunert et al., 2012). Among the possible explanations for higher transpiration in mixed stands is complementarity in resource uptake, which e.g. has been demonstrated for the mentioned stands in Panama with a water stable isotope ( $\delta^{18} \mathrm{O}$ and $\left.\delta \mathrm{D}\right)$ approach (Schwendenmann et al., 2015).

There are studies from China applying such an approach in rubber tree mixed cultivation systems. In mixture with Flemingia macrophylla rubber trees took up water near the soil surface in the rainy season and from deeper soil strata in the dry period (Wu et al., 2016a). In the dry period rubber trees took up water from lower layers than the F. macrophylla, which was interpreted as an effect of competition. Plasticity in 
water uptake depths and competitive displacement of rubber tree water uptake was also indicated in an intercropping experiment with tea, coffee and cacao plants (Wu et al., 2016b). However, the studied experimental rubber agroforestry cultivation systems (tea, coffee and cacao) are intensive production systems, while an approach towards 'greener' rubber latex production would probably involve the integration of native tree species (Tomich et al., 1998; van Noordwijk et al., 2012); this would introduce a greater variability in plant size. Various previous isotope studies on soil water uptake partitioning have found influences of tree size on water uptake depth (Meinzer et al., 1999; Meißner et al., 2012; Hombegowda et al., in review).

Rubber cultivation in mixed stands with native trees is by far not a modern invention. In its native region, rubber trees occur dispersed as one of the many tree species in the Amazonian lowland rainforest (Porro et al., 2012). On Sumatra, Indonesia jungle rubber cultivation has a long-standing tradition. Smallholders planted rubber trees amid native tree species that naturally regenerated after slashing and burning rainforest (Gouyon et al., 1993). It was a widespread land-use system in the lowlands of Jambi, Sumatra until the mid-20 ${ }^{\text {th }}$ century (Gouyon et al., 1993; Joshi et al., 2002; van Noordwijk et al., 2012). Today, jungle rubber stands are often replaced by oil palm or rubber mono-cultural plantations (Williams et al., 2001; Drescher et al., 2016). Nonetheless, such stands still exist; they can be considered models of 'green' rubber production.

Our study was carried out in the lowlands of Sumatra in the province of Jambi, where in remote rural areas rubber tree cultivation is a dominant land use. Today, rubber tree cultivation mostly has the form of mono-cultural plantations, but some jungle rubber stands can still be found. The objectives of our study were to compare tree water use rates and tree soil water uptake depths between mono-cultural and mixed jungle rubber stands, with a particular focus on the role of tree diameter.

\subsection{Methods}

\subsubsection{Study area and plots}

Our study was carried out in the lowlands of Jambi province, Sumatra, Indonesia. In the past, the lowlands of Jambi province were dominated by forest and jungle rubber but in recent decades monoculture plantations of oil palm and rubber trees expanded. Average annual precipitation in Jambi's lowlands was $2235 \mathrm{~mm} \mathrm{yr}^{-1}$ and the mean annual temperature was $27^{\circ} \mathrm{C}$ (Drescher et al., 2016). The study was implemented in 
the Harapan landscape as part of the EFForTS project (Drescher et al., 2016, Figure 4.1). Four plots each were analyzed in the two different rubber cultivation systems, i.e. in monoculture rubber plantations and jungle rubber stands. Plots were $50 \times 50 \mathrm{~m}$ in size, located on moderate slopes and at similar altitude. Soil type was loam Acrisol. Plantation age of the monocultures varied between 14 and 17 years, while the age of rubber trees in the jungle rubber stands lay between 16 and 18 years (Drescher et al., 2016). Average tree diameter and height were relatively similar in both cultivation types but basal area and stand density were higher in the jungle rubber stands (Kotowska et al., 2015, Table 4.1). Rubber trees had average shares of $30 \%$ of stem density and $26 \%$ of basal area in jungle rubber. Overall net primary productivity was by $38 \%$ higher and latex yield per unit of land was $66 \%$ lower in jungle rubber than in the rubber monocultures (Kotowska et al., 2015).

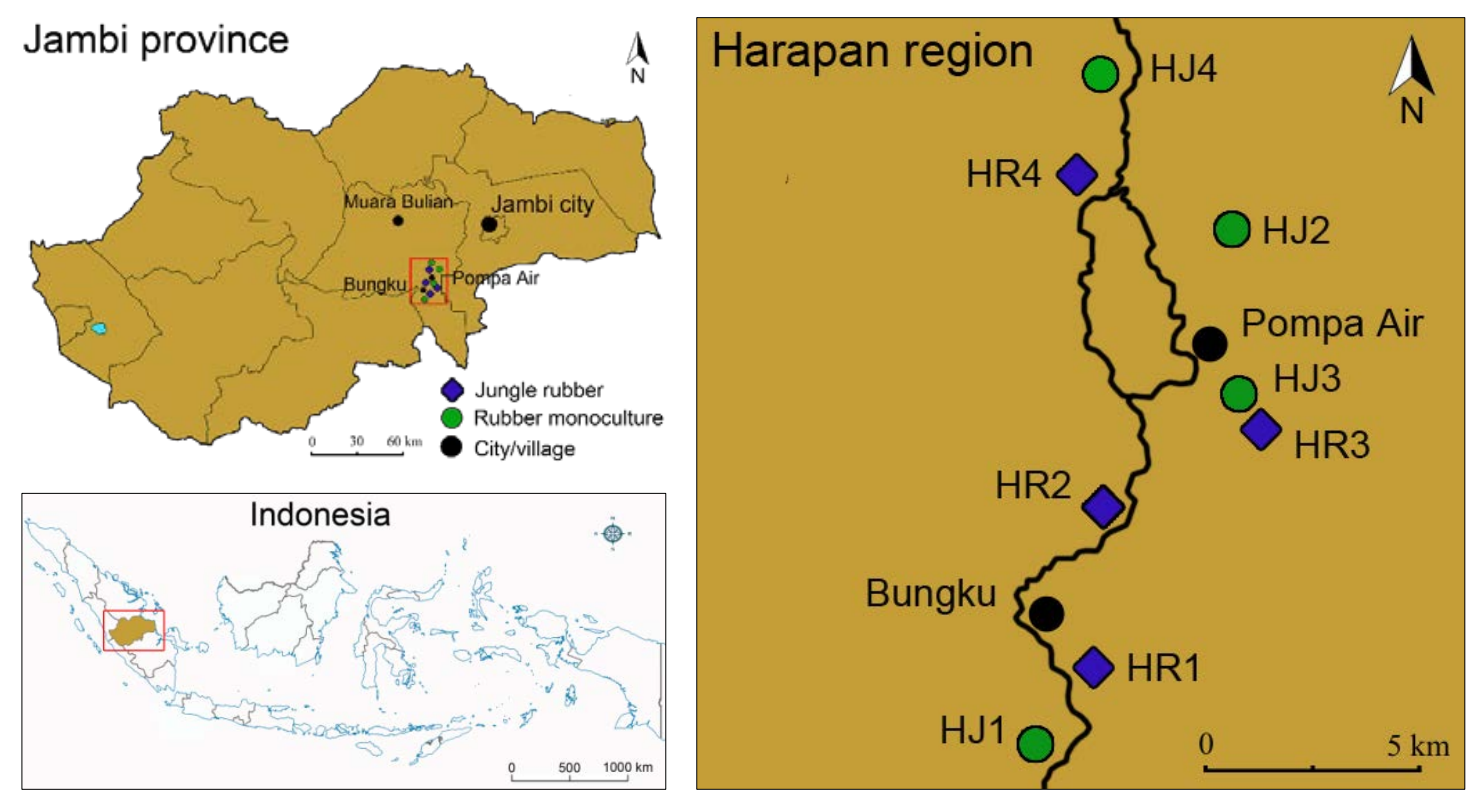

Figure 4.1. The study region in Jambi province, Indonesia. The study was conducted in the Harapan region and consists of four plots each in rubber monoculture (HR) and jungle rubber $(\mathrm{HJ})$ stands.

\subsubsection{Tree water use}

In all eight stands, we measured sap flux density $J_{s}\left(\mathrm{~g} \mathrm{~cm}^{-2} \mathrm{~h}^{-1}\right)$ with Granier type (Granier, 1985) thermal dissipation probes (TDP). In each rubber monoculture six trees were equipped with two TDP sensors. In jungle rubber stands, eight trees, four rubber trees and four admixed native trees species were equipped with two TDP sensors. The selected trees belonged to the dominant or co-dominant vertical strata. 
The selected tree species in jungle rubber were Cratoxylum sumatranum, Callerya atropurpurea, Ixonanthes petiolaris, Santiria griffithii, Macaranga cf. sumatrana, Artocarpus nitidus, Alstonia angustifolia, Streblus elongates, Artocarpus integer, Porterandia anisophylla, and Timonius wallichianus, which were abundant in these stands. Sap flux measurements were run for about four weeks in each plot (Table 4.A1).

On each sample tree, two TDP sensors (length $2.5 \mathrm{~cm}$ ) were installed, at breast height $(1.3 \mathrm{~m})$ on native trees and at a height of approx. $2 \mathrm{~m}$ on rubber trees, i.e. well above the area that is frequently cut for extraction of rubber latex. Insulative materials, aluminum foil and plastic foil were used to cover and shield the sensors. They were connected to data loggers (CR1000, Campbell Scientific Inc.), which recorded data every $30 \mathrm{~s}$ and averaged and stored them in 10 minute intervals. Based on results from laboratory and field experiments on rubber trees (Niu et al., in review), we calculated sap flux density $\left(J_{s}, \mathrm{~g} \mathrm{~cm}^{-2} \mathrm{~h}^{-1}\right)$ with the original parameters for the sap flux calibration equation by Granier (1985).

For scaling to tree water use $\left(\mathrm{kg} \mathrm{d}^{-1}\right)$, radial profiles measured with the heat field deformation (HFD) technique were used (for rubber see Niu et al., in review; for admixed native trees see Röll, 2015). We calculated (daily) tree water use for each sample tree by multiplying day sums of sap flux density $\left(\mathrm{kg} \mathrm{cm}^{-2} \mathrm{~d}^{-1}\right)$ and the water conductive area adjusted for radial changes in $J_{\mathrm{s}}$ (Niu et al., in review, following Oishi et al. 2008). Based on available tree diameter data for all plots (Kotowska et al., 2015), the diameter-dependent water conductive areas for each tree within a certain stand could be calculated and summed up to obtain stand water conductive areas.

To calculate tree water use, we multiplied the corresponding water conductive areas by the $J_{\mathrm{s}}$ day sums derived as the mean of two sensors per tree. For calculating the mean tree water use of a certain plot, the corresponding mean tree water conductive area per stand was multiplied by the mean $J_{s}$ of all sensors that were running simultaneously in that same plot; stand-scale transpiration was calculated by substituting the average for the summed-up stand water conductive area. Because sap flux measurements were conducted in different periods and we were mostly interested in pattern across stands, we reduced the influence of environmental variables by focusing the analyses on three sunny days per stand; data on global radiation and vapor pressure deficit of the air are provided in Table 4.A1. Average soil moisture during the period of sap flux measurements was 32 vol. \%; it fluctuated little during the measurement period and was thus regarded non-limiting. 
Micrometeorological variables were measured at a station in Pompa Air in the vicinity of the study plots (Figure 4.1). Data from a Thermohygrometer (Thies Clima) were used to calculate vapor pressure deficit (VPD) of the air based air temperature and relative humidity. We measured global radiation $\left(R_{\mathrm{g}}, \mathrm{MJ} \mathrm{m}^{-2}\right.$ day $\left.^{-1}\right)$ with a radiation sensor (CMP3 Pyranometer, Kipp \& Zonen). Data were recorded every $15 \mathrm{~s}$ and stored and averaged in 10 minute intervals by data loggers (LogTrans 16-GPRS, UIT) (Meijide et al., 2017). Additionally, soil moisture data were recorded hourly by a data logger (LogTrans 16-GPRS, UIT) connected to soil moisture sensors (Trime-Pico 32, IMKO). The sensors were installed in the center of all eight study plots at $0.3 \mathrm{~m}$ depth.

\section{Tree soil water uptake}

For the assessment of tree water uptake depths the sampling scheme regarding number of plots ( $n=4$ per cultivation system) and within-plot replicates was the same as in the tree water use study ( $n=6$ in rubber monocultures; $n=4$ rubber trees and $n=4$ native trees in jungle rubber stands). However, not always the same trees were studied: $58 \%$ of the rubber trees and $56 \%$ of the admixed native trees were identical to those on which sap flux was measured. Soil and xylem samples were taken on average 9 days (range: 6 to 12 days) after the last rain event (Table 4.A1). On one jungle rubber plot $(\mathrm{HJ} 4)$ it began to rain during sampling. From this plot, only data from rubber trees but not from native admixed trees are available. An auger was used to obtain soil samples at depths of 0-20, 20-40, 40-60, and 60-100 cm. Each sample was a mixture of three different soil cores, taken from varying directions around the trunk of a sample tree (at $1.5 \mathrm{~m}$ distance). We took xylem tissue samples of all sample trees from the outer $5 \mathrm{~cm}$ of the xylem using an increment borer at the mentioned three directions (at breast height). The outer bark was removed after sample collection to avoid xylem water contamination by phloem water. We stored the samples in $40 \mathrm{ml}$ glass bottles immediately after extraction. Bottles were closed with Teflon coated lids. We sealed all bottles with Parafilm and subsequently kept them frozen until the water extraction process in the laboratory (Ehleringer et al., 2000). We extracted water from all wood and soil samples via cryogenic vacuum extraction (Ehleringer and Osmond 1989). Extraction times were $70 \mathrm{~min}$ for soil and $90 \mathrm{~min}$ for wood samples (West et al., 2006). The analyses of the extracted water samples for $\delta^{18} \mathrm{O}$ and $\delta \mathrm{D}$ was performed at the Center for Stable Isotope Research and Analysis (KOSI, George August-Universität Göttingen, Germany). A high temperature conversion elemental analyzer (TC/EA, Thermo Electron Corporation, Bremen, Germany) that was coupled to a Delta $\vee$ Plus isotope ratio mass spectrometer 
(Thermo Electron Corporation) by a Con-Flo III interface (Gehre et al., 2004) were used for the analyses. The ratios of the examined stable isotopes were expressed as per mill deviations in relation to Vienna Standard Mean Ocean Water (VSMOW, $\mathrm{R}_{\text {Standard }}$ ) (Gonfiantini, 1978). Measurement precision was $\pm 2 \%$ for $\delta \mathrm{D}$.

To identify at which depths the sample trees took up water, we employed the SIAR mixing model (Stable Isotope Analysis in R, SIAR package, version 3.0.2, Parnell et al., 2010), which calculates the proportionate contribution to plant water uptake for each soil depth through a Bayesian framework. The model was run with 30000 iterations for each tree, the resulting probability distributions were averaged.

\section{Statistical analysis}

To obtain maximum $J_{s}$ values $\left(J_{\text {smax }}\right)$, the diurnal 90 -percentiles of hourly $J_{s}$ on three sunny days (Table A1) were averaged; the 90-percentiles were used to minimize the influence of potential outliers, while (three) sunny days were used in order to minimize day-to-day variability of $J_{\text {smax }}$ due to varying weather conditions.

Analysis of variance (ANOVA, $p<0.05$ ) was applied to determine the fractional water uptake differences, i.e. vertically within cultivation type and horizontally within a given depth across cultivation types. Linear regressions were applied to analyze relationship between several variables (e.g. tree diameter and water use, $\delta^{18} \mathrm{O}(\%)$ and $\delta \mathrm{D}(\%)$ water isotopes of xylem and soil, and transpiration and stand density). All statistical analysis was done in $\mathrm{R}$ 3.0.2 ( $\mathrm{R}$ Development Core Team). 
Tabel 4.1. Tree and stand characteristics of the studied rubber monocultures and jungle rubber stands.

\begin{tabular}{|c|c|c|c|c|c|c|c|c|c|c|}
\hline & \multirow[b]{2}{*}{ Plot code } & \multicolumn{4}{|c|}{ Rubber trees } & \multicolumn{4}{|c|}{ Admixed native trees } & \multirow{2}{*}{$\begin{array}{c}\text { Total } \\
\begin{array}{c}\text { Basal } \\
\text { area } \\
\left(\mathrm{m}^{2} \mathrm{ha}^{-1}\right)\end{array}\end{array}$} \\
\hline & & $\begin{array}{l}\text { Density } \\
(\text { trees ha } \\
\text { (t) }\end{array}$ & $\begin{array}{l}\text { Tree diameter } \\
(\mathbf{c m}) \\
\text { mean } \pm \text { se }\end{array}$ & $\begin{array}{l}\text { Tree height } \\
(\mathrm{m}) \\
\text { mean } \pm \text { se }\end{array}$ & $\begin{array}{c}\text { Basal } \\
\text { area } \\
\left(m^{2} h a^{-1}\right)\end{array}$ & $\begin{array}{l}\text { Density } \\
\left(\text { trees ha }^{-1}\right)\end{array}$ & $\begin{array}{l}\text { Tree diameter } \\
\left(\begin{array}{c}(\mathrm{cm}) \\
\text { mean } \pm \text { se }\end{array}\right.\end{array}$ & $\begin{array}{l}\text { Tree height } \\
(\mathrm{m}) \\
\text { mean } \pm \text { se }\end{array}$ & $\begin{array}{c}\text { Basal area } \\
\left(\mathrm{m}^{2} \mathrm{ha}^{-1}\right)\end{array}$ & \\
\hline \multirow{5}{*}{$\begin{array}{l}\text { Rubber } \\
\text { monoculture }\end{array}$} & HR1 & 348 & $21.2 \pm 1.2$ & $14.4 \pm 0.4$ & 12.7 & - & - & - & - & 12.7 \\
\hline & HR2 & 300 & $20.5 \pm 1.4$ & $13.9 \pm 0.2$ & 8.4 & - & - & - & - & 8.4 \\
\hline & HR3 & 444 & $18.4 \pm 2.0$ & $13.0 \pm 0.2$ & 11.9 & - & - & - & - & 11.9 \\
\hline & HR4 & 668 & $21.0 \pm 2.6$ & $12.4 \pm 0.2$ & 16.0 & - & - & - & - & 16.0 \\
\hline & HR1-HR4 & $440 \pm 81.7$ & $20.3 \pm 0.6$ & $13.4 \pm 0.4$ & $12.2 \pm 1.6$ & - & - & - & - & $12.2 \pm 1.6$ \\
\hline \multirow{5}{*}{$\begin{array}{l}\text { Jungle } \\
\text { rubber }\end{array}$} & $\mathrm{HJ1}$ & 216 & $17.8 \pm 2.0$ & $14.9 \pm 0.5$ & 7.5 & 132 & $18.2 \pm 2.2$ & $14.6 \pm 0.7$ & 7.9 & 15.4 \\
\hline & $\mathrm{HJ} 2$ & 160 & $17.3 \pm 2.1$ & $13.1 \pm 0.4$ & 4.2 & 400 & $18.3 \pm 2.0$ & $13.9 \pm 0.3$ & 13.3 & 17.5 \\
\hline & $\mathrm{HJ3}$ & 144 & $16.9 \pm 2.0$ & $13.4 \pm 0.3$ & 2.6 & 432 & $18.5 \pm 2.0$ & $14.1 \pm 0.3$ & 14.1 & 16.7 \\
\hline & $\mathrm{HJ} 4$ & 104 & $19.1 \pm 1.4$ & $14.8 \pm 0.5$ & 3.0 & 512 & $17.0 \pm 1.5$ & $13.5 \pm 0.3$ & 13.7 & 16.7 \\
\hline & HJ1-HJ4 & $156 \pm 23.2$ & $17.8 \pm 0.5$ & $14.0 \pm 0.5$ & $4.3 \pm 1.1$ & $369 \pm 82.4$ & $18.0 \pm 0.3$ & $14.0 \pm 0.2$ & $12.2 \pm 1.5$ & $16.6 \pm 0.4$ \\
\hline
\end{tabular}




\subsection{Results}

\subsubsection{Tree water use and stand transpiration}

Maximum sap flux densities $\left(J_{\text {smax }}\right)$ and tree water use rates were relatively similar across trees species and cultivation type (Table 4.2). In rubber trees in monocultures, only a small part of the observed variation in $J_{\text {smax }}$ was explained by tree diameter (linear regression, $r^{2}=0.19, p<0.05$ ); in the jungle rubber stands, $J_{\text {smax }}$ increased with increasing diameter in rubber trees $\left(r^{2}=0.68, p<0.01\right)$, but decreased in native trees $\left(r^{2}=0.45, p<0.05\right)$ (Figure 4.3). For all tree categories, tree water use increased linearly with increasing tree diameter; the slopes of the linear regressions were 2.8 and 2.4 for rubber trees in monocultures and jungle rubber, respectively. For admixed trees in jungle rubber, the slope was less than half (Figure 4.3). Stand transpiration in jungle rubber was $27 \%$ higher than in rubber monocultures (Table 2). Across the eight stands, transpiration scaled linearly with stand density $\left(r^{2}=0.85, p<0.01\right)$ (Figure 4.A5).

Soil moisture as measured in the center of the eight study plots (at $30 \mathrm{~cm}$ depth) with permanently installed sensors did not have a significant effect on day-to-day variability of $J_{\text {smax }}$, average water use or stand transpiration. Where data was available (frequent measurement gaps at all sites) and exceeding our measurement period, soil moisture at $30 \mathrm{~cm}$ depth remained relatively high and fluctuated relatively little at all sites, even after consecutive days without rainfall. It was thus considered to be non-limiting for transpiration during our measurement period.

\subsubsection{Tree soil water uptake}

In our study, $\delta^{18} O$ and $\delta D$ isotope ratios were significantly correlated for soil $\left(r^{2}=\right.$ $0.70, p<0.001)$ and xylem $\left(r^{2}=0.58, p<0.001\right)$ samples (Figure 4.A1). Also, ecological interpretations are very similar (Figures 4.A3 and 4.A4). In the following, we focus on the $\delta^{18} \mathrm{O}$ data only.

At the time of sampling, soil moisture (established based on soil sampling at different depths) increased from the soil surface to deeper soil strata (Figure 4.A2). Soil water $\delta^{18} \mathrm{O}$ ratios were less negative in the upper stratum than deeper in the soil. The SIAR 
mixing model (Figure 4.2) suggests that rubber trees in monocultures had their main uptake depths in the stratum from 20 to $40 \mathrm{~cm}$ of soil depth (36\%). Rubber trees in jungle rubber stands took up a significantly lower share of water at this depth $(24 \%, p$ $<0.05)$. Their main uptake depth was in 40 to $60 \mathrm{~cm}$ of soil depth (28\%). Admixed native trees in jungle rubber stands had their main uptake depth in 20 to $40 \mathrm{~cm}$ of soil depth (31\%).

$\delta^{18} \mathrm{O}$ isotope ratios in xylem were significantly related to tree diameters (Figure 4.3), particularly in rubber trees and admixed species in jungle rubber stands $\left(r^{2}=0.58, p<\right.$ 0.001 ). In conjunction with the pattern of $\delta^{18} \mathrm{O}$ ratio changes with soil depth (Figure 4.A2) this indicates that bigger trees tended to take up soil water closer to the soil surface, while smaller trees tended to take up water from deeper layers.
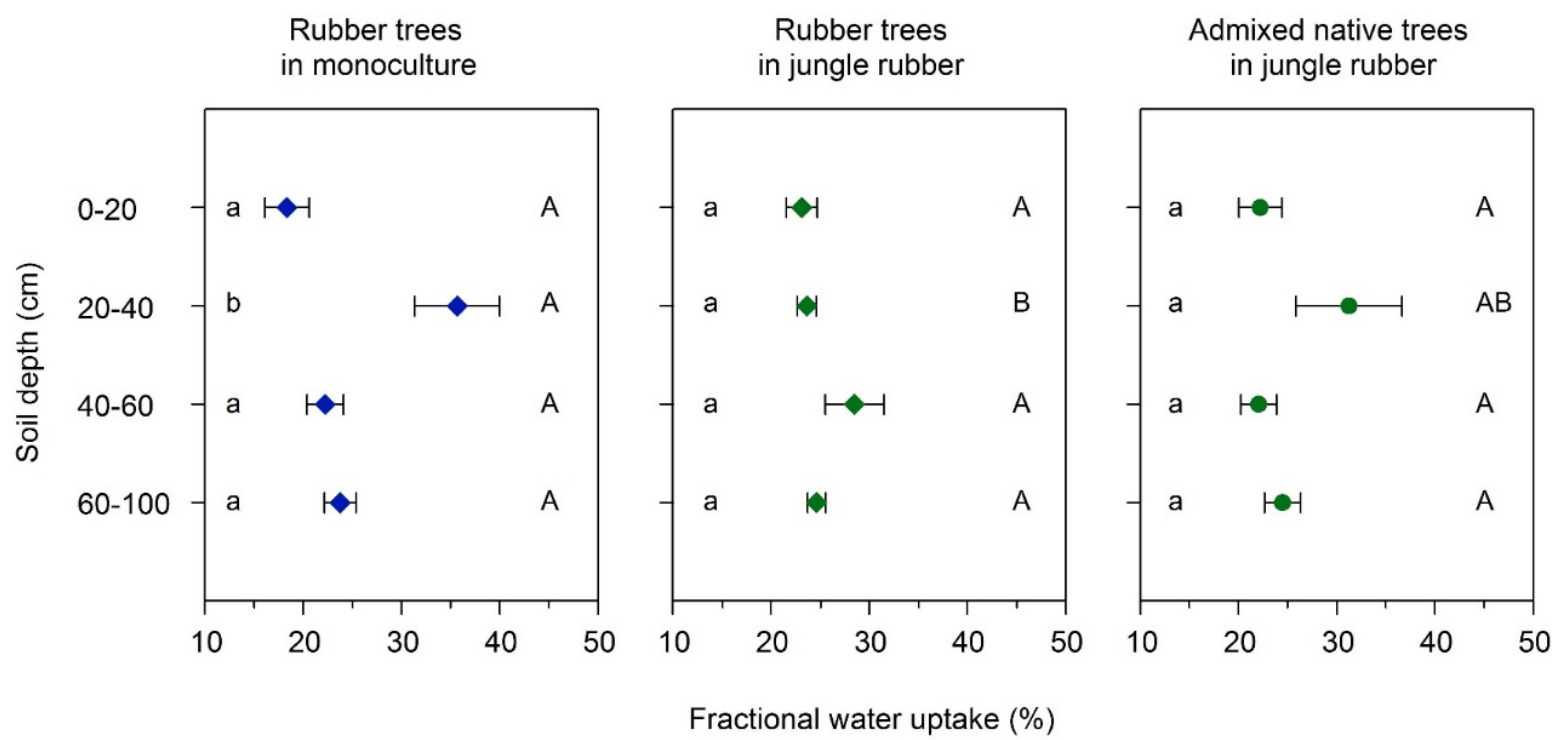

Figure 4.2. Percentage of water uptake from different soil depths based on $\delta^{18} \mathrm{O}$ analyses and the application of a SIAR mixing model. Means and standard errors; $n=21$ (rubber trees in monoculture), $n=14$ (rubber tree in jungle rubber), and $n=10$ (admixed native trees in jungle rubber). Small letters indicate significant vertical differences of fractional water uptake within a cultivation type; significant horizontal differences within a given depth across cultivation types are indicated by capital letters $(p<0.05$; ANOVA). 
Tabel 4.2. Maximum sap flux density $\left(\mathrm{J}_{\mathrm{smax}}\right)$, water use, and stand transpiration of the rubber monoculture and jungle rubber stands (sunny days, mean and standard errors, $n=4$ each).

\begin{tabular}{|c|c|c|c|c|c|c|c|}
\hline & \multicolumn{3}{|c|}{ Rubber trees } & \multicolumn{3}{|c|}{ Admixed native trees } & \multirow{2}{*}{$\begin{array}{c}\text { Total } \\
\text { Transpiration } \\
\left(\mathrm{mm} \mathrm{d}^{-1}\right) \\
\text { mean } \pm \text { se }\end{array}$} \\
\hline & $\begin{array}{c}J_{\operatorname{smax}} \\
\left(\mathrm{g} \mathrm{cm}^{-2} \mathrm{~h}^{-1}\right) \\
\text { mean } \pm \text { se }\end{array}$ & $\begin{array}{l}\text { Water use } \\
\left(\mathrm{kg} \mathrm{d}^{-1}\right) \\
\text { mean } \pm \text { se }\end{array}$ & $\begin{array}{l}\text { Transpiration } \\
\qquad\left(\mathrm{mm} \mathrm{d}^{-1}\right) \\
\text { mean } \pm \text { se }\end{array}$ & $\begin{array}{c}J_{s m a x} \\
\left(\mathrm{~g} \mathrm{~cm}^{-2} \mathrm{~h}^{-1}\right) \\
\text { mean } \pm \mathrm{se}\end{array}$ & $\begin{array}{l}\text { Water use } \\
\left(\mathrm{kg} \mathrm{d}^{-1}\right) \\
\text { mean } \pm \text { se }\end{array}$ & $\begin{array}{l}\text { Transpiration } \\
\qquad\left(\mathrm{mm} \mathrm{d}^{-1}\right) \\
\text { mean } \pm \mathrm{se}\end{array}$ & \\
\hline Rubber monoculture & $14.9 \pm 1.5$ & $25.6 \pm 3.7$ & $1.1 \pm 0.2$ & - & - & - & $1.1 \pm 0.2$ \\
\hline Jungle rubber & $14.3 \pm 1.4$ & $24.1 \pm 4.2$ & $0.4 \pm 0.1$ & $14.6 \pm 2.1$ & $26.7 \pm 2.2$ & $1.0 \pm 0.2$ & $1.4 \pm 0.2$ \\
\hline
\end{tabular}




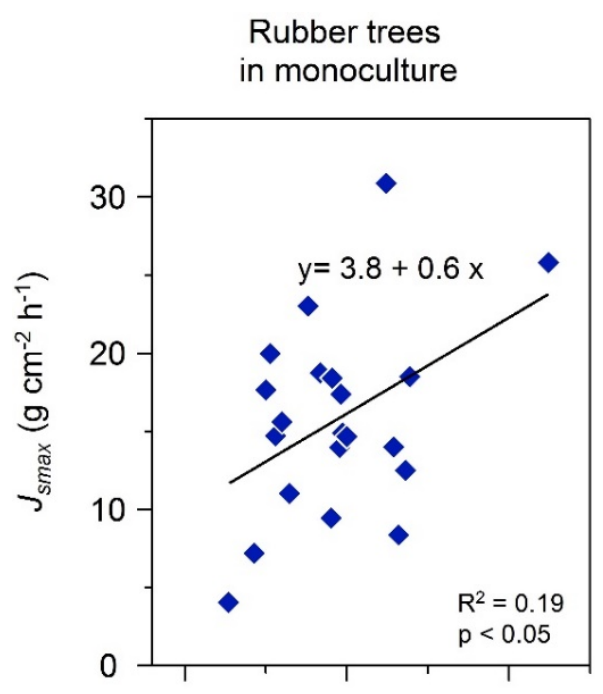

Rubber trees

in jungle rubber
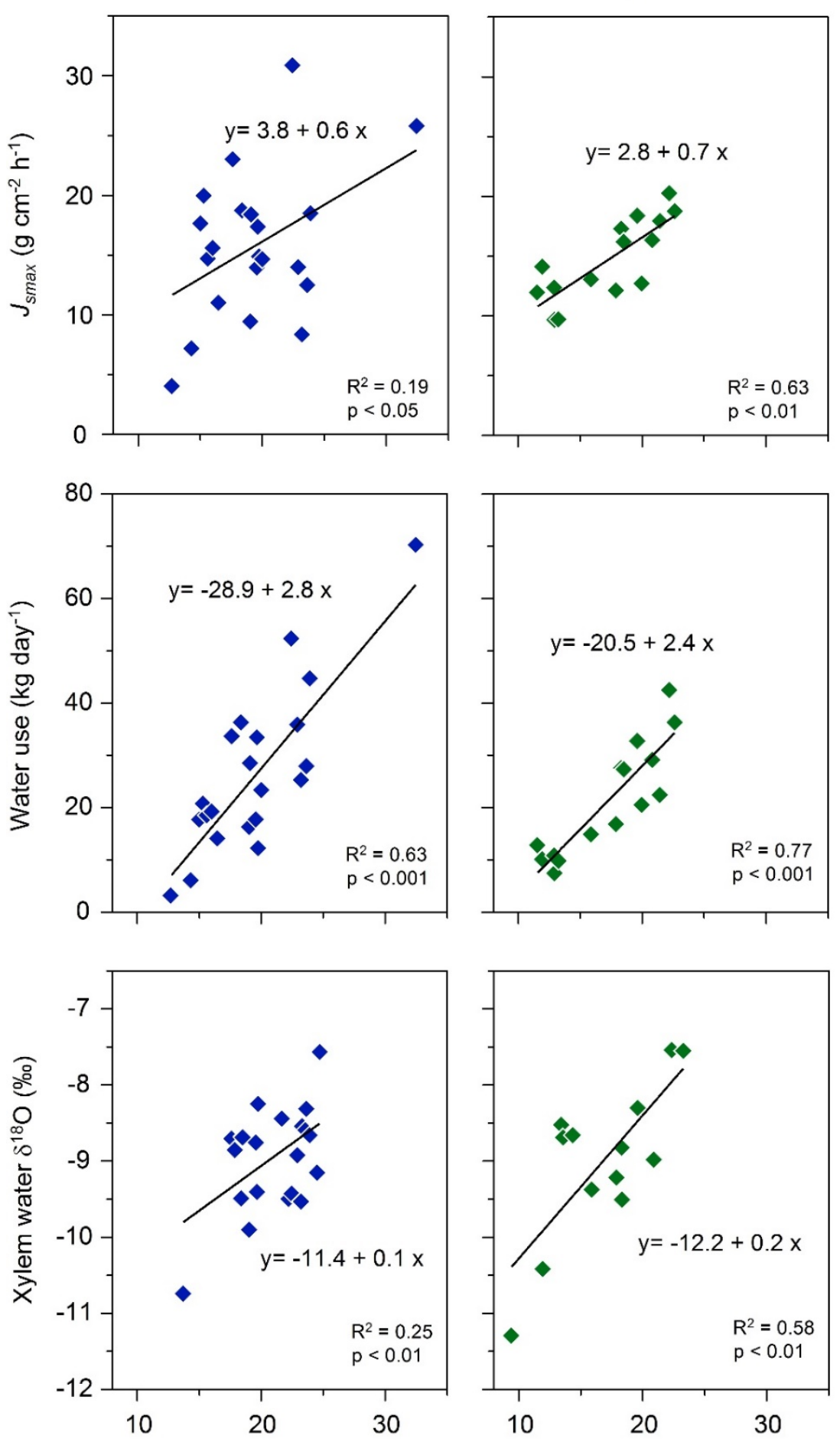

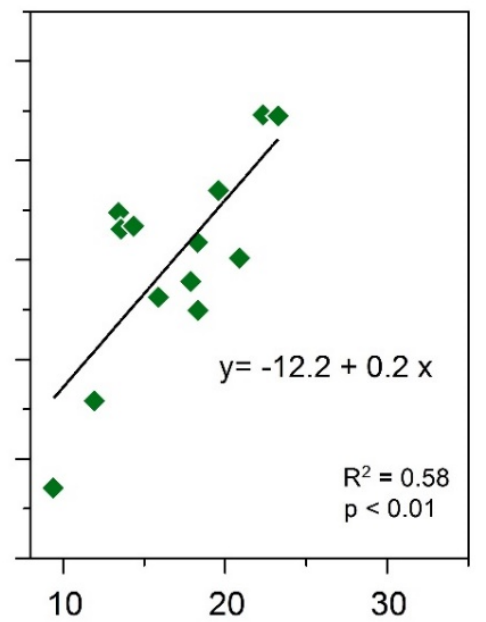

Tree diameter $(\mathrm{cm})$

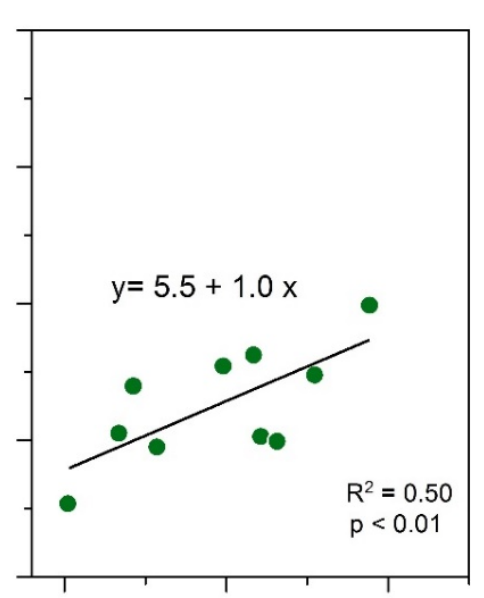

Admixed native trees

in jungle rubber
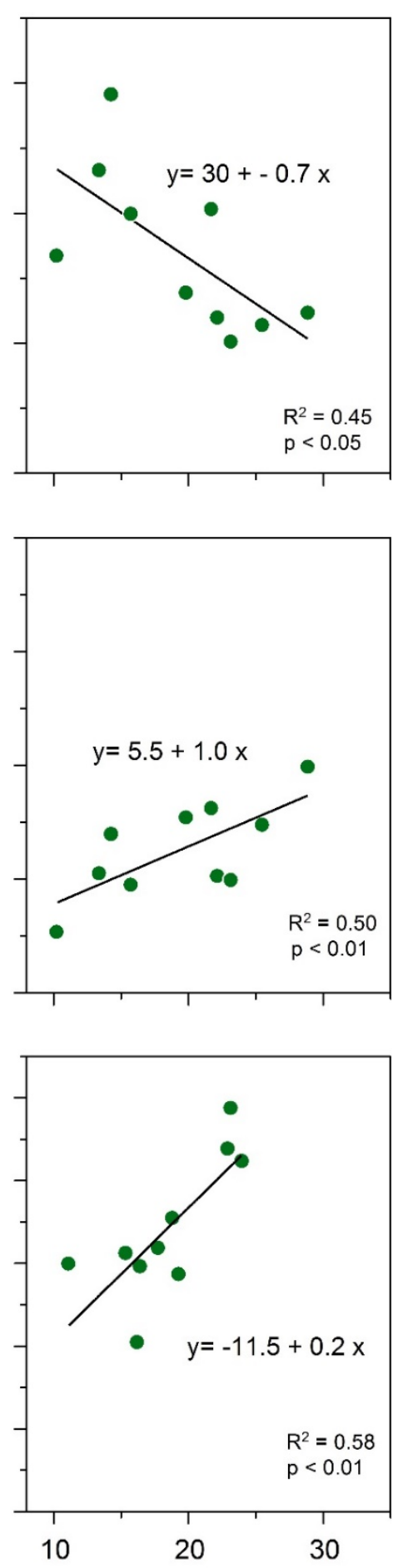

Figure 4.3. Maximum sap flux density $\left(J_{s \max }\right)$ and tree water use on sunny days, and xylem isotopic $\delta^{18} \mathrm{O}$ signatures, in relation to tree diameter for rubber trees in monocultures and for rubber trees and admixed native tree species in jungle rubber stands. 


\subsection{Discussion}

In the studied mono-cultural and mixed 'jungle' rubber stands, we found similar rates of mean tree water use, enhanced stand transpiration in jungle rubber stands due to high stand densities, and plasticity of rubber trees in soil water uptake depth. Tree size had a strong influence on both tree water use rates and soil water uptake depths.

In our study, we used well-established methodological approaches and measurement schemes. For sap flux measurements on rubber trees, we followed Niu et al. (in review), who confirmed the TDP-based field measurement scheme applied in our study (i.e. using the original (Granier, 1985) equation parameters) in laboratory experiments and field trials with reference methods. Based on radial profile measurements with heat field deformation sensors, we used a rubber-specific extrapolation scheme for all rubber trees (Niu et al. in review), and a common scheme for admixed species in jungle rubber (Röll, 2015) to calculate individual tree water use rates. Regarding the extrapolation from the tree-level to stand transpiration, a further potential source of error, Kobayashi et al. (2014) quantify the estimation error in stand transpiration due to limited sample size (i.e. number of TDP sensors) with our measurement scheme (e.g. six sap flux sample trees with two sensors each in rubber monocultures) with approx. 10\%. Stand-scale transpiration estimation errors are likely higher in the more heterogeneous jungle rubber stands; they can e.g. be higher than $30 \%$ for natural old-growth forest stands (Granier et al., 1996). However, regardless of potential errors in absolute transpiration rates, our study was mainly designed to investigate relative differences in water use patterns among trees and stands; to accurately quantify such relative differences in patterns is regarded a strength of sap flux approaches.

The scaling of tree water use mainly with tree size is in accordance with many other studies (e.g. Meinzer et al., 2001, 2005). We found a much stronger increase for rubber trees than for the admixed native tree species, which is related to differences in the $J_{\text {smax }}$ to tree diameter relationship. $J_{\text {smax }}$ increased with increasing diameter in rubber trees, but decreased for native tree species. Reasons for such differences in sap flux patterns have been reported to include differences in pathway resistance to water transport or in the ratio of leaf to sapwood area (Schäfer et al., 2000; McDowell et al., 2002; Buckley and Roberts, 2006; Ryan et al., 2006). Divergences in the latter can be induced by both differences in leaf and sapwood area among trees. Some of the native tree species are early successional and already showed signs of 
senescence, which may contribute to the decreasing $J_{\text {smax }}$ with increasing tree diameter. A potential reason for the increases in $J_{\text {smax }}$ with increasing diameter in rubber trees (in both cultivation systems), as opposed to the decreases in native tree species and to decreases reported in a variety of previous studies ('functional convergence', Meinzer et al., 2001, 2005), could be that the diameter range of the studied rubber trees $(4.5-36.7 \mathrm{~cm})$ was too small to make the effects of functional convergence visible. This has previously been reported for relatively young tree plantations and agroforestry stands with similarly small diameter ranges as in our study (Dierick et al., 2010), where effects of functional convergence could be masked by stronger effects, e.g. of tree exposure, environmental conditions or stand structural differences (Cienciala et al., 2000; Meinzer et al., 2001). A more detailed discussion of potential (physiological) mechanisms behind the absence of decreasing $J_{\text {smax }}$ with increasing diameter in (some) rubber tree monoculture plantations can be found in Niu et al. (in review). Despite the differences in $J_{\text {smax }}$, when extrapolating from sap flux point measurements to whole-tree water use with the HFD-derived radial sap flux profiles, at the overall mean tree diameter $(19 \mathrm{~cm})$ there was very little difference between water use rates of rubber and those of native trees. At the stand level, transpiration of jungle rubber was $27 \%$ higher than that of rubber monocultures, which was strongly related to higher stem densities (and higher basal area) in jungle rubber stands. Similarly, in Panamian tree plantations, water use increased with increasing stand basal area, and also with increasing species richness (Kunert et al., 2012). Australian mixed eucalypt-acacia plantations also had higher stand transpiration than (eucalypt) monocultures, which was attributed to higher basal and leaf area (Forrester et al., 2010). Higher water use in the mixed jungle rubber stands also goes along with findings that the total net primary productivity of jungle rubber was about $38 \%$ higher than in the rubber monocultures (Kotowska et al., 2015). Generally, both the average stand transpiration values of the rubber monocultures $\left(1.1 \mathrm{~mm} \mathrm{~d}^{-1}\right)$ and the jungle rubber stands $\left(1.4 \mathrm{~mm} \mathrm{~d}^{-1}\right)$ seem modest when compared to the range provided by multiple water use studies in tropical agroforestry, reforestation and plantation stands (0.5-2.3 $\left.\mathrm{mm} \mathrm{d}^{-1}\right)$, as reviewed by Röll et al. (2015). However, the main focus of our study was to investigate relative differences in patterns rather than to provide estimates of absolute transpiration rates.

Complementary use of resources often enhances the performance of mixed-species assemblages (Vandermeer, 1989). In case of (economically) differently valued crops in cultivation systems, resource partitioning should be in favor of the main crop, in our 
case the rubber trees. During a relatively dry period and after 6-12 consecutive days without precipitation, we found that the main rubber tree water uptake in the monocultures took place relatively close to the soil surface, whereas rubber trees in jungle rubber stands mainly took up water from deeper soil strata; here, the native trees had their main uptake depth close to the soil surface. This pattern indicates competitive displacement of rubber tree water uptake. Plasticity in soil water uptake depth by rubber trees was also found in other mixed rubber cultivation systems with Flemingia macrophylla, tea, coffee and cacao plants. It was interpreted as an effect of competitive displacement (Wu et al., 2016a and b). There is thus emerging evidence of plasticity in rubber tree water resource uptake and competitive displacement by cooccurring woody species.

In the available data set there was little evidence of an influence of the potential rubber tree water uptake depth on tree sap flux and water use. On sunny days immediately after rainfall to six days after last rainfall sap flux densities in rubber trees in monoculture were reduced by $9 \%$, those of rubber trees in jungle rubber by $16 \%$ and those of admixed native trees in jungle rubber by $10 \%$. The relatively larger reductions in rubber trees in jungle rubber could be a result of competitive displacement in rubber water uptake depth. However, our available data set is too limited to further assess these effects.

In our study $\delta^{18} \mathrm{O}$ in xylem water changed with tree diameter, indicating that larger diameter trees took up water from soil layers closer to the surface and smaller diameter trees from deeper layers. This relationship was particularly evident in the jungle rubber stands. There are contrasting findings on this issue in the existing literature: significant positive linear relationships of tree $\mathrm{DBH}$ and water uptake depths of canopy trees were reported in old-growth tropical (Meinzer et al., 1999) and advanced temperate forests (Meißner et al., 2012) and well as in established tropical coffee agroforests (Hombegowda, 2015). In an old-growth rain forest in French Guiana consisting of different vertical strata a significant relationship between water uptake depth and DBH existed, but it explained only a relatively small portion of the observed variance (Stahl et al., 2013). In contrast, no correlations between water uptake depth and DBH were found in a young tropical tree plantation (Schwendenmann et al., 2015) and a young temperate forest plantation (Grossiord et al., 2014). In extension to the arguments of Leuschner et al. (2009), who list advantages and disadvantages of synthetic stands and established forests in studies on the functional role of tree diversity, it was argued that young artificial plantations do 
not have an apparent diameter to soil depth relationship yet because such an arrangement of soil resource space partitioning probably needs time and interaction among neighbors (Hombegowda et al., in review). Following this line of reasoning, the studied jungle rubber stands, which showed significant water uptake depth to DBH relationships and where competitive displacement of rubber water uptake was indicated, are more dense assemblages where enough time has passed and interaction among trees of different diameter classes has taken place for resource partitioning to occur.

In conclusion, across eight sites in rubber monocultures and jungle rubber stands in the lowlands of Jambi, Indonesia, tree diameter was a central variable of influence for both, tree and stand water use rates and tree water uptake depths. Stand density also played a prominent role as a potential controlling factor of tree and stand water use. Thus, thinning measures, e.g. by cutting larger native trees in mixed jungle rubber stands, appear as a potentially viable management option for influencing water uptake patterns and stand transpiration rates in favor of the cultivated rubber trees.

\section{Acknowledgments}

We gratefully acknowledge the support of the German Research Foundation (DFG, CRC 990, A02 and ABS projects), which funded our study. Afik Hardanto received a scholarship from the Indonesian-German Scholarship Programme (IGSP). We would like to thank Heri Junaedi and Andrea Hanf for field support and cooperation. Our sincere gratitude also goes to Agusta Herdhata and Surya Tarigan for constructive cooperation, Katja Rembold (B06-sub project) for identifying admixed tree species in jungle rubber plots and Ana Meijide (A03- and Z02-sub projects) for providing micrometeorological data. Special recognition must also be given to our field assistants Ali, Bayu and Ferry for supporting us at all times during the field measurements. 


\section{References}

Beukema, H., Danielsen, F., Vincent, G., Hardiwinoto, S., and van Andel, J. (2007). Plant and bird diversity in rubber agroforests in the lowlands of Sumatra, Indonesia. Agrofor. Syst. 70 (3), 217-242. doi:10.1007/s10457-007-9037-x.

Buckley, T. N., and Roberts, D. W. (2006). How should leaf area, sapwood area and stomatal conductance vary with tree height to maximize growth? Tree Physiol. 26 (2), 145-157. doi:10.1093/treephys/26.2.145.

Bush, S. E., Hultine, K. R., Sperry, J. S., and Ehleringer, J. R. (2010). Calibration of thermal dissipation sap flow probes for ring- and diffuse-porous trees. Tree Physiol. 30, 1545-1554. doi:10.1093/treephys/tpq096.

Cienciala, E., Kučera, J., and Malmer, A. (2000). Tree sap flow and stand transpiration of two acacia mangium plantations in Sabah, Borneo. J. Hydrol. 236 (1): 109-120. doi: 10.1016/S0022-1694(00)00291-2

Clearwater, M. J., Meinzer, F. C., Andrade, J. L., Goldstein, G., and Holbrook, N. M. (1999). Potential errors in measurement of nonuniform sap flow using heat dissipation probes. Tree Phys. 19 (10): 681-687. doi:10.1093/treephys/19.10.681.

Dierick, D., Kunert, N., Köhler, M., Schwendenmann, L., and Hölscher, D. (2010). Comparison of tree water use characteristics in reforestation and agroforestry stands across the tropics. In: Tropical rainforests and agroforests under global change. Springer Berlin Heidelberg, pp. 293-308.

Drescher, J., Rembold, K., Allen, K., Beckschäfer, P., Buchori, D., Clough, Y., et al. (2016). Ecological and socio-economic functions across tropical land use systems after rainforest conversion. Phil. Trans. R. Soc. B. 371, 20150275. doi:10.1098/rstb.2015.0275.

Ehleringer, J. R., and Osmond, C. B. (1989). "Stable isotopes," in Plant Physiological Ecology Field Methods and Instrumentation, eds. R.W. Percy, J.R. Ehleringer, H.A. Mooney and P.R. Rundel (London: Chapman and Hall Ltd), 281-300.

Ehleringer, J. R., Roden, J. S., and Dawson, T. E. (2000). "Assessing ecosystemlevel water relations through stable isotope ratio analyses," in Methods in Ecosystem Science, eds. O.E. Sala, R.B. Jackson, H.A. Mooney and R.W. Howarth (New York: Springer-Verlag), 181-198.

FAO. (2016). FAOSTAT online statistical service: Food and agriculture organization of the United Nations (FAO). Rome, Italy. Available online at: http://faostat.fao.org/. (Accessed April 10, 2016)

Forrester, D. I., Theiveyanathan, S., Collopy, J. J., and Marcar, N. E. (2010). Enhanced water use efficiency in a mixed Eucalyptus globulus and Acacia mearnsii plantation. Forest Ecol. Manag. 259 (9), 1761-1770. doi:10.1016/j.foreco.2009.07.036.

Forrester, D. I. (2015). Transpiration and water-use efficiency in mixed-species forests versus monocultures: effects of tree size, stand density and season. Tree Physiol. 35 (3), 289-304. doi:10.1093/treephys/tpv011. 
Fox, J., Vogler, J. B., Sen, O. L., Giambelluca, T. W., and Ziegler, A. D. (2012). Simulating land-cover change in Montane mainland Southeast Asia. Environ. Manag. 49 (5), 968-979. doi:10.1007/s00267-012-9828-3.

Gehre, M., Geilmann, H., Richter, J., Werner, R. A., and Brand, W. A. (2004). Continuous flow $2 \mathrm{H} / 1 \mathrm{H}$ and $18 \mathrm{O} / 16 \mathrm{O}$ analysis of water samples with dual inlet precision. Rapid Commun. Mass Sp. 18 (22), 2650-2660. doi:10.1002/rcm.1672.

Giambelluca, T. W., Mudd, R. G., Liu, W., Ziegler, A. D., Kobayashi, N., Kumagai, T., et al. (2016). Evapotranspiration of rubber (Hevea brasiliensis) cultivated at two plantation sites in Southeast Asia. Water Resour. Res. 52 (2), 660-79. doi:10.1002/2015WR017755.

Gonfiantini, R. (1978). Standards for stable isotope measurements in natural compounds. Nature 271, 534-536. doi:10.1038/271534a0.

Gouyon, A., Foresta, H. D. E, and Levang, P. (1993). Does 'jungle rubber' deserve its name? An analysis of rubber agroforestry systems in Southeast Sumatra. Agrofores. Syst. 22, 181-206. doi:10.1007/BF00705233.

Granier, A. (1985). Une nouvelle méthode pour la mesure du flux de sève brute dans le tronc des arbres. Ann. For. Sci. 42, 193-200. doi:10.1051/forest:19850204

Granier, A., Biron, P., Bréda, N., Pontailler, J. Y., and Saugier, B. (1996). Transpiration of trees and forest stands: short and long-term monitoring using sapflow methods. Glob. Change Biol. 2, 265-274.

Grossiord, C., Gessler, A., Granier, A., Berger, S., Bréchet, C., Hentschel, R., et al. (2014). Impact of interspecific interactions on the soil water uptake depth in a young temperate mixed species plantation. J. Hydrol. 519, 3511-3519. doi:10.1016/j.jhydrol.2014.11.011.

Hombegowda, H. C. (2015). Soil carbon under agroforestry systems of Southern India. [dissertation]. [Göttingen, Germany]: Georg-August-Universität Göttingen

Hu, H., Liu, W., and Cao, M. (2008). Impact of land use and land cover changes on ecosystem services in Menglun, Xishuangbanna, Southwest China. Environ. Monit. Assess. 146 (1-3), 147-156. doi:10.1007/s10661-007-0067-7.

Joshi, L., Akiefnawati, R., Boutin, D., Manurung, G., van Noordwijk, M., Vincent, G., et al. (2002). Jungle rubber: A traditional agroforestry system under pressure. International Centre for Research in Agroforestry (ICRAF). Bogor. Indonesia. Available online at: http://www.worldagroforestry.org/publication/jungle-rubbertraditional-agroforestry-system-under-pressure (Accessed July 19, 2016).

Kobayashi, N., Kumagai, T., Miyazawa, Y., Matsumoto, K., Tateishi, M., Lim, T. K., et al. (2014). Transpiration characteristics of a rubber plantation in Central Cambodia. Tree Physiol. 34, 285-301. doi:10.1093/treephys/tpu009.

Kotowska, M. M., Leuschner, C., Triadiati, T., Meriem, S., and Hertel, D. (2015). Quantifying above- and belowground biomass carbon loss with forest conversion in tropical lowlands of Sumatra (Indonesia). Glob. Change Biol. 21 (10), 3620-3634. doi:10.1111/gcb.12979. 
Kume, T., Onozawa, Y., Komatsu, H., Tsuruta, K., Shinohara, Y., Umebayashi, T., et al. (2010). Stand-scale transpiration estimates in a Moso bamboo forest: (I) Applicability of sap flux measurements. For. Ecol. Manag. 260, 1287-1294. doi:10.1016/j.foreco.2010.07.012.

Kunert, N., Schwendenmann, L., Potvin, C., and Hölscher, D. (2012). Tree diversity enhances tree transpiration in a Panamanian forest plantation: Tree transpiration in a tropical plantation. J. Appl. Ecol. 49 (1), 135-144. doi:10.1111/j.1365-2664.2011.02065.x.

Leuschner, C., Jungkunst, H. F., and Fleck, S. (2009). Functional role of forest diversity: pros and cons of synthetic stands and across-site comparisons in established forests. Basic Appl. Ecol. 10 (1): 1-9. doi:10.1016/j.baae.2008.06.001.

Lu, P., Urban, L., and Ping, Z. (2004). Granier's thermal dissipation probe (TDP) method for measuring sap flow in trees: theory and practise. Acta Bot. Sin. 46, 631-646.

McDowell, N. G., Barnard, H., Bond, B. J., Hinckley T., Hubbard R. M., Ishii H., et al. (2002). The relationship between tree height and leaf area: sapwood area ratio. Oecologia 132 (1), 12-20. doi:10.1007/s00442-002-0904-x.

Meijide,A., Röll, A., Fan, Y., Herbst, M., Niu, F., Tiedemann, F., June, T., Rauf, A., Hölscher, D., and Knohl, A. (2017, in press). Controls of water and energy fluxes in oil palm plantations: environmental variables and oil palm age. Agric. For. Meteorol. 239, 71-85. doi: 10.1016/j.agrformet.2017.02.034.

Meinzer, F. C., Andrade, J. L., Goldstein, G., Holbrook, N. M., Cavelier, J., and Wright, S. J. (1999). Partitioning of soil water among canopy trees in a seasonally dry tropical forest. Oecologia 121 (3), 293-301. doi:10.1007/s004420050931.

Meinzer, F. C., Goldstein, G., and Andrade, J. L. (2001). Regulation of water flux through tropical forest canopy trees: do universal rules apply? Tree Physiol. 21 (1), 19-26. doi: 10.1093/treephys/21.1.19.

Meinzer, F. C., Bond, B. J. Warren, J. M. and Woodruff, D. R. (2005). Does water transport scale universally with tree size? Funct. Ecol. 19 (4), 558-565. doi: 10.1111/j.1365-2435.2005.01017.x.

Meißner, M., Köhler, M., Schwendenmann, L., and Hölscher, D. (2012). Partitioning of soil water among canopy trees during a soil desiccation period in a temperate mixed forest. Biogeosciences 9 (8), 3465-3474. doi:10.5194/bg-9-3465-2012.

Niu, F., Roll, A., Hardanto, A., Meijide, A., Kohler, M., Hendrayanto, et al. (2015). Oil palm water use: calibration of a sap flux method and a field measurement scheme. Tree Physiol. 35, 563-573. doi:10.1093/treephys/tpv013.

Oishi, A. C, Oren, R., and Stoy, P. C. (2008). Estimating components of forest evapotranspiration: a footprint approach for scaling sap flux measurements. Agric. For. Meteorol. 148 (11), 1719-1732. doi:10.1016/j.agrformet.2008.06.013. 
Parnell, A. C., Inger, R., Bearhop, S., and Jackson, A. L. (2010). Source partitioning using stable isotopes: Coping with too much variation. PLoS ONE 5 (3), e9672. doi:10.1371/journal.pone.0009672.

Porro, R., Miller, R. P., Tito, M. R., Donovan, J. A., Vivan, J. L., Trancoso, R., et al. (2012). "Agroforestry in the Amazon region: a pathway for balancing conservation and development," in Agroforestry-The Future of Global Land Use, eds. P. K. R. Nair and D. Garrity (Dordrecht, NL: Springer), 391-428.

Röll, A., Niu, F., Meijide, A., Hardanto, A., Hendrayanto, Knohl, A., and Hölscher, D. (2015). Transpiration in an oil palm landscape: effects of palm age. Biogeosciences 12 (12): 9209-9242. doi:10.5194/bgd-12-9209-2015.

Röll, A. (2015). Changes in eco-hydrological functioning after tropical rainforest transformation to rubber and oil palm plantations. [Dissertation]. [Göttingen, Germany]. Available online at: https://ediss.unigoettingen.de/handle/11858/00-1735-0000-0023-9641-F (Accessed July 26, 2016).

Ryan, M. G., Phillips, N., and Bond, B. J. (2006). The hydraulic limitation hypothesis revisited. Plant Cell Environ. 29 (3), 367-381. doi:10.1111/j.13653040.2005.01478.x.

Schäfer, K. V. R., Oren, R., and Tenhunen, J. D. (2000). The effect of tree height on crown level stomatal conductance. Plant Cell Environment 23 (4), 365-375. doi:10.1046/j.1365-3040.2000.00553.x.

Schwendenmann, L., Pendall, E., Sanchez-Bragado, R., Kunert, N., and Hölscher, D. (2015). Tree water uptake in a tropical plantation varying in tree diversity: Interspecific differences, seasonal shifts and complementarity. Ecohydrology 8 (1), 1-12. doi:10.1002/eco.1479.

Stahl, C., Hérault, B., Rossi, V., Burban, B., Bréchet, C., and Bonal, D. (2013). Depth of soil water uptake by tropical rainforest trees during dry periods: does tree dimension matter? Oecologia 173 (4), 1191-1201. doi:10.1007/s00442-0132724-6.

Tan, Z. H., Zhang, Y. P., Song, Q. H., Liu, W. J., Deng, X. B., Tang, J. W. et al. (2011). Rubber plantations act as water pumps in tropical China. Geophysical Research Letters 38 (24), L24406. doi:10.1029/2011GL050006.

Tomich, T. P, van Noordwijk, M., Budidarsono, S., Gilison, A., Kusumanto, T., Murdiyarso, D., et al. (1998). Alternatives to slash-and-burn in Indonesia, summary report and synthesis of phase II. Bogor, Indonesia: World Agroforestry Centre (ICRAF). Available online at: http://outputs.worldagroforestry.org/cgi-bin/koha/opacdetail.pl?biblionumber=35566 (Accessed November 29, 2016).

van Noordwijk, M., Pfund, J. L., Bakarr, M., Jackson, L., Schroth, G., Hairiah, K., and Joshi, L. (2006). Agro-biodiversity and CGIAR tree and forest science: Approaches and examples from Sumatra. ICRAF working paper, Bogor, Indonesia. Available at: http://www.worldagroforestry.org/sea/Publications/ files/workingpaper/WP0076-06.PDF (Accessed November 28, 2016). 
van Noordwijk, M., Tata, H. L., Xu, J., Dewi, S., and Minang, P. A. (2012). "Segregate or integrate for multifunctionality and sustained change through rubber-based agroforestry in Indonesia and China," in Agroforestry-The Future of Global Land Use, eds. P. K. R. Nair and D. Garrity (Dordrecht: Springer Netherlands), 69-104. Available at: http://link.springer.com/10.1007/978-94-007-4676-3_8 (Accessed July 20, 2016).

Vandermeer, J. H. (1989). The Ecology of Intercropping. Cambridge, UK: Cambridge University Press.

Villamor, G. B., Le, Q. B., Djanibekov, U., van Noordwijk, M., and Vlek, P. L. G. (2014). Biodiversity in rubber agroforests, carbon emissions, and rural livelihoods: an agent-based model of land-use dynamics in lowland Sumatra. Environ. Model. Softw. 61, 151-165. doi:10.1016/j.envsoft.2014.07.013.

Warren-Thomas, E., Dolman, P. M., and Edwards, D. P. (2015). Increasing demand for natural rubber necessitates a robust sustainability initiative to mitigate impacts on tropical biodiversity: Rubber sustainability and biodiversity. Conserv. Lett. 8 (4), 230-241. doi:10.1111/conl.12170.

West, J. B., Bowen, G. J., Cerling, T. E., and Ehleringer, J. R. (2006). Stable isotopes as one of nature's ecological recorders. Trends Ecol. Evol. 21 (7), 408-414. doi:10.1016/j.tree.2006.04.002.

Williams, S. E., van Noordwijk, M., Penot, E., Healey, J. R., Sinclair, F. L., and Wibawa, G. (2001). On-farm evaluation of the establishment of clonal rubber in multistrata agroforests in Jambi, Indonesia. Agrofor. Syst. 53 (2), 227-237. doi:10.1023/A:1013336822923.

Wu, J., Liu, W., and Chen, C. (2016a). Below-ground interspecific competition for water in a rubber agroforestry system may enhance water utilization in plants. Sci. Rep. 6, 19502. doi:10.1038/srep19502.

Wu, J., Liu, W., and Chen, C. (2016b). Can intercropping with the world's three major beverage plants help improve the water use of rubber trees? J. Appl. Ecol. doi:10.1111/1365-2664.12730.

Ziegler, A. D., Fox, J. M., and Xu, J. (2009). The rubber juggernaut. Science 324 (5930), 1024-1025. doi:10.1126/science.1173833. 


\section{Appendix}
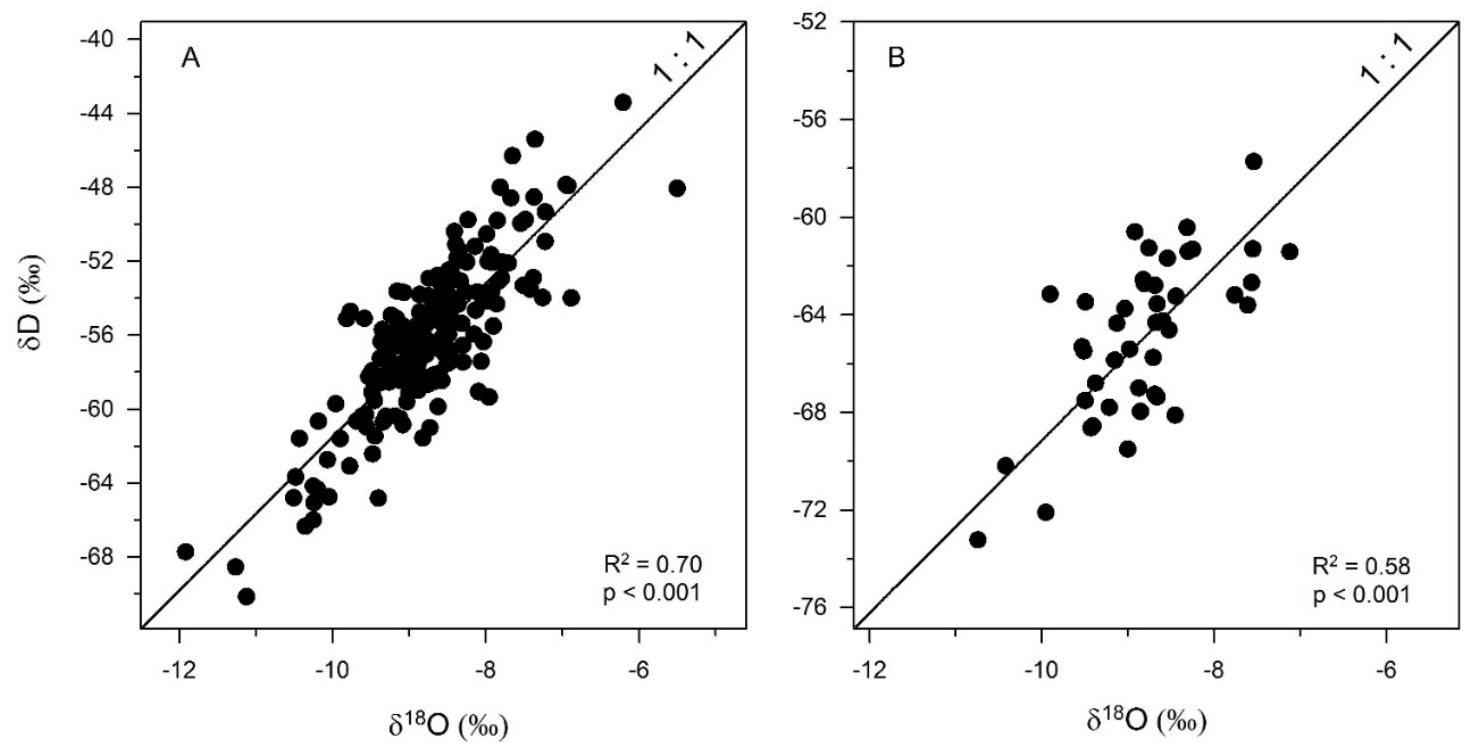

Figure 4.A1. Relationship between Xylem water $\delta^{18} \mathrm{O}(\%)$ and $\delta D(\%)$ for soil water (A) and xylem water (B). The lines indicate a 1:1 relationship. 

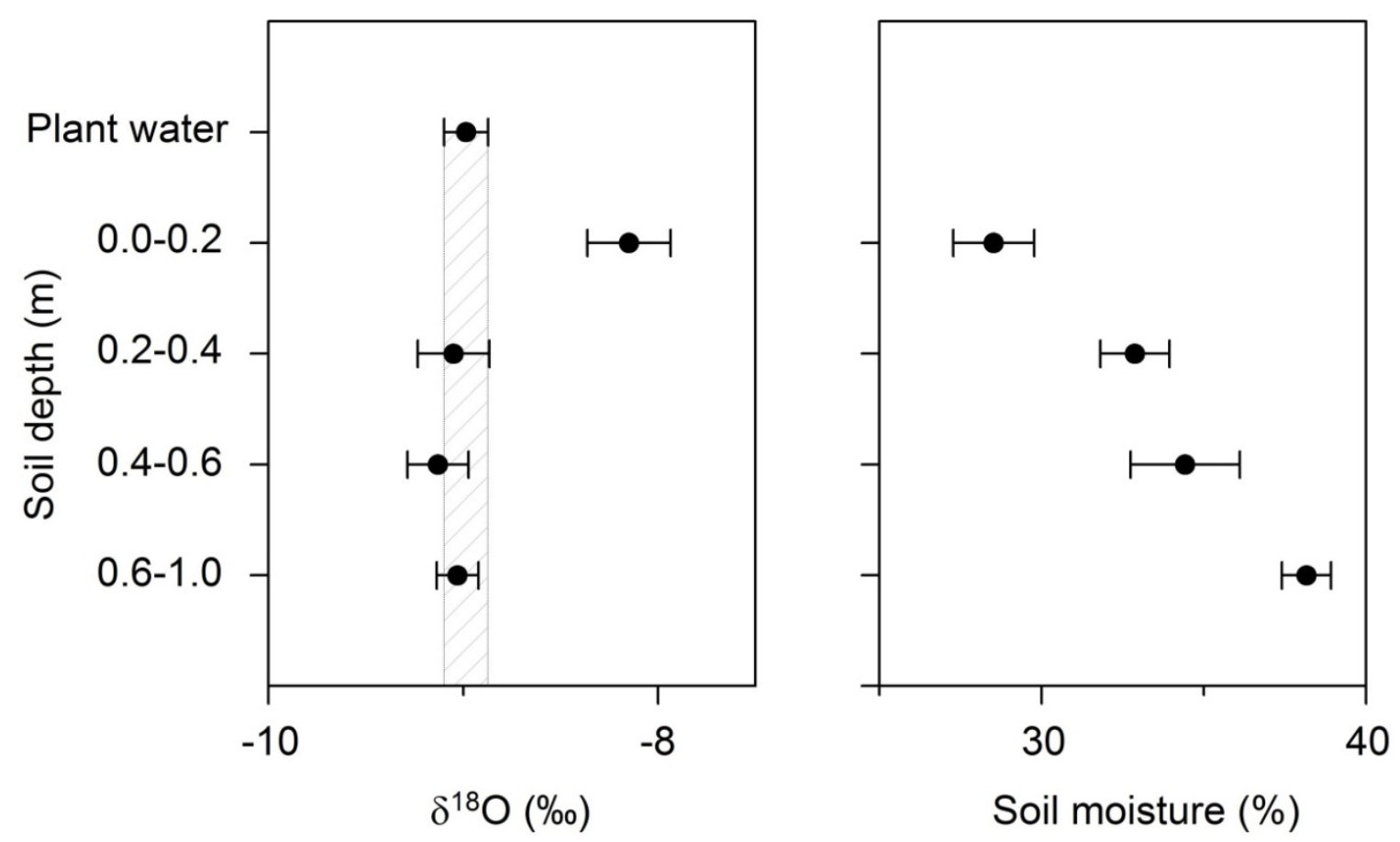

Figure 4.A2. Isotopic $\delta^{18} \mathrm{O}$ signatures of plant and gravimetric soil water (with increasing depth) for the sample trees in our study. Data of all land use types and species pooled. Values are means $\pm s d(n=45)$. 

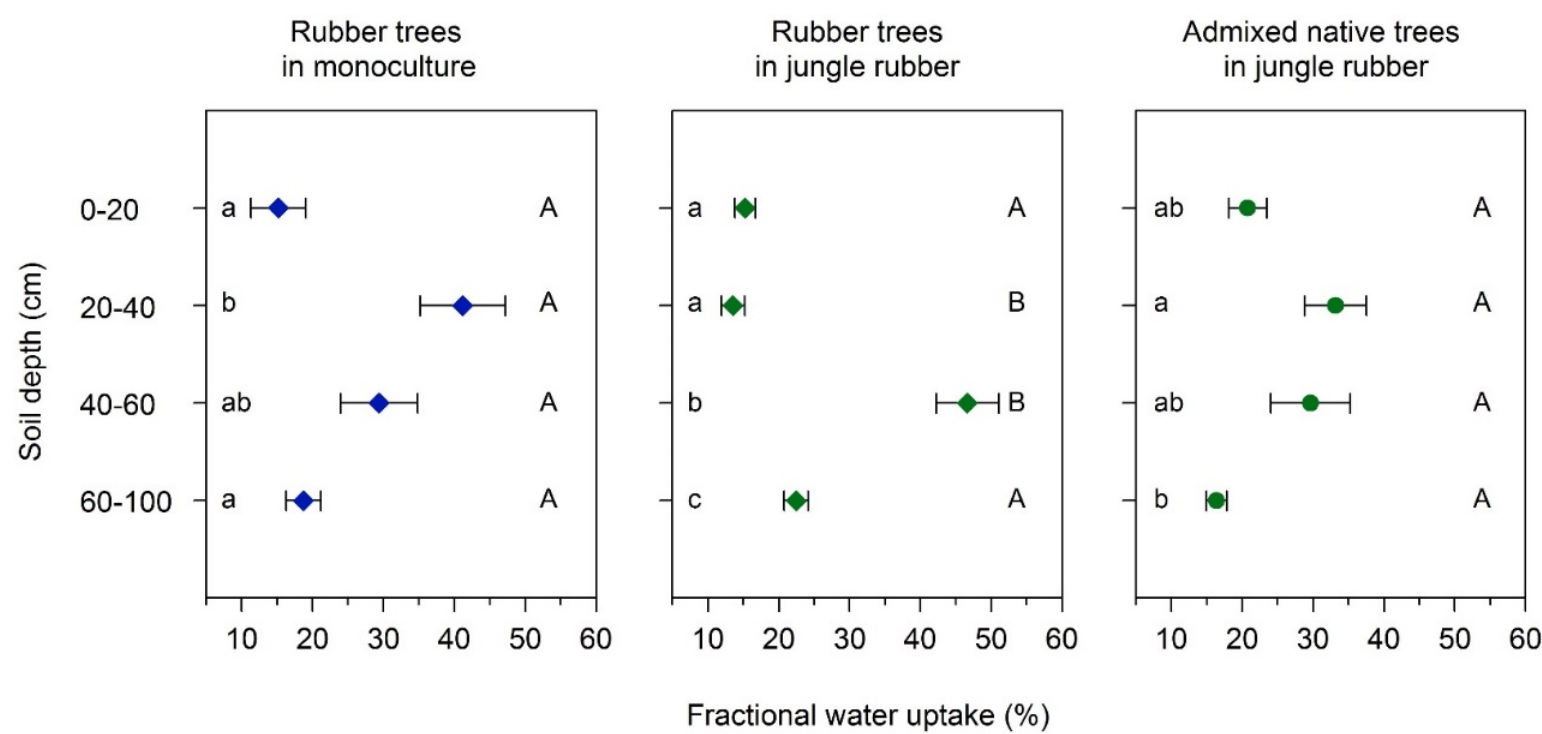

Figure 4.A3. Percentage of water uptake from different soil depths as based on $\delta D$ analyses and the application of a SIAR mixing model. Means and standard errors; $\mathrm{n}=21$ (rubber monoculture), $\mathrm{n}=14$ (rubber trees in jungle rubber), and $\mathrm{n}=10$ (admixed native trees in jungle rubber). Small letters indicate significant vertical differences of fractional water uptake within a cultivation type; significant horizontal differences within a given depth across cultivation types are indicated by capital letters $(p<0.05$; ANOVA). 

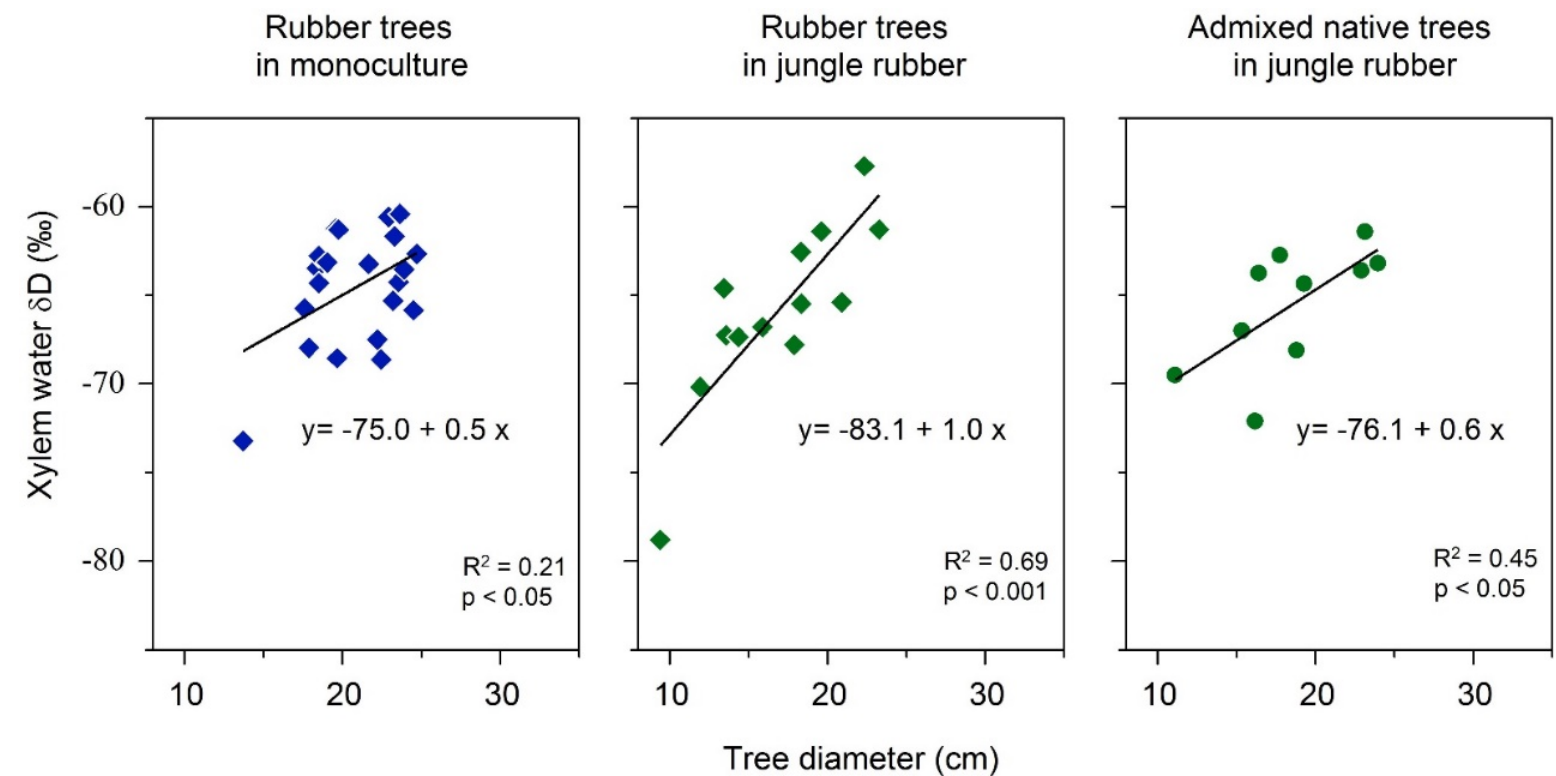

Figure 4.A4. Xylem $\delta D$ in relation to tree diameter for rubber trees in monocultures and for rubber trees and admixed native tree species in jungle rubber stands. 

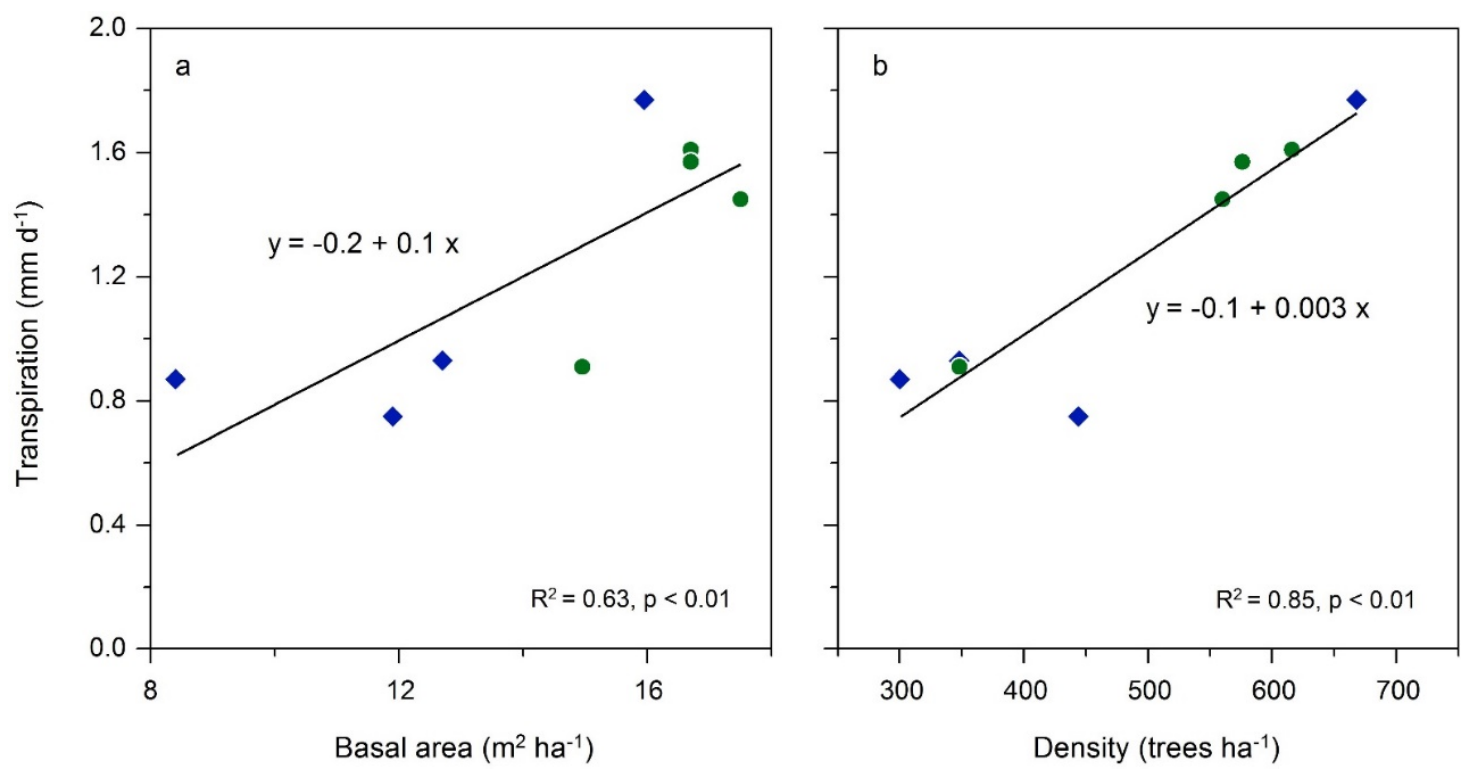

Figure 4.A5. Stand transpiration plotted against basal area (a) and stand density (b). Data for eight plots encompassing rubber monocultures $(n=4$, blue rhombuses) and jungle rubber stands ( $n=4$, green circles). 
Table 4.A1. Study period and environmental characteristics (three sunny days, means and standard errors) in the respective study plots in rubber monoculture plantations and jungle rubber stands.

\begin{tabular}{|c|c|c|c|c|c|c|}
\hline & \multirow[b]{2}{*}{ Plot code } & \multicolumn{3}{|c|}{ Sap flux study } & \multicolumn{2}{|c|}{ Isotopes study } \\
\hline & & Period of measurement & $\begin{array}{c}R_{\mathrm{g}} \\
\left(\mathrm{MJ} \mathrm{m}^{-2} \mathrm{~d}^{-1}\right) \\
\text { mean } \pm \mathrm{se}\end{array}$ & $\begin{array}{c}\text { VPD } \\
(\mathrm{kPa}) \\
\text { mean } \pm \text { se }\end{array}$ & $\begin{array}{l}\text { Days of } \\
\text { sampling }\end{array}$ & $\begin{array}{l}\text { Days after last } \\
\text { rainfall event } \\
\quad \text { (days) }\end{array}$ \\
\hline \multirow[t]{4}{*}{ Rubber monoculture } & HR1 & 24 Nov 2013 to 13 Jan 2014 & $16.9 \pm 0.8$ & $1.3 \pm 0.1$ & 19 Jun 2013 & 6 \\
\hline & HR2 & 26 Jul 2013 to 2 Sep 2013 & $18.8 \pm 0.8$ & $1.9 \pm 0.1$ & 21 Jun 2013 & 8 \\
\hline & HR3 & 4 Sep 2013 to 23 Sep 2013 & $23.1 \pm 0.2$ & $2.1 \pm 0.1$ & 23 Jun 2013 & 10 \\
\hline & HR4 & 18 May 2013 to 23 Jul 2013 & $22.4 \pm 0.8$ & $2.0 \pm 0.2$ & 25 Jun 2013 & 12 \\
\hline \multirow[t]{4}{*}{ Jungle rubber } & $\mathrm{HJ1}$ & 26 Oct 2013 to 22 Nov 2013 & $18.2 \pm 0.9$ & $1.7 \pm 0.2$ & 20 Jun 2013 & 7 \\
\hline & $\mathrm{HJ} 2$ & 26 Sep 2013 to 29 oct 2013 & $19.7 \pm 1.3$ & $1.9 \pm 0.3$ & 24 Jun 2013 & 11 \\
\hline & $\mathrm{HJ3}$ & 9 Sep 2013 to 24 Sep 2013 & $21.8 \pm 0.6$ & $2.1 \pm 0.1$ & 22 Jun 2013 & 9 \\
\hline & $\mathrm{HJ} 4$ & 18 May 2013 to 3 Jun 2013 & $18.0 \pm 1.0^{b)}$ & $1.4 \pm 0.2^{b)}$ & 17 Aug $2013^{c)}$ & 7 \\
\hline
\end{tabular}

a) Days after rain (average \pm se) in each cultivation plot for isotopes study, i.e. $9.0 \pm 2.6$ and $8.5 \pm 1.9$ days for rubber monoculture and jungle rubber, respectively.

b) Data from a micrometeorological station in PT. Reki (Approx. $40 \mathrm{~km}$ distance), as the usually used station in Pompa Air was non-functional at the time of sap flux measurements.

${ }^{c}$ During sampled in $\mathrm{HJ} 4$ plot, the rain was starting when we took samples with admixed native trees species. Thus we did not use the four admixed native trees samples included the soil samples because of contaminated by rain. 
Chapter 5

SYNTHESIS 


\section{Chapter 5 Synthesis}

\subsection{Overview of this work}

Drawback in biodiversity conservation (Fitzherbert et al. 2008) and water resources problem (e.g. Tan et al., 2011; Merten et al. 2016) due to post forest monoculture plantation had previously been revealed. In the lowlands of Jambi characterized by undulating topography with periodic flood events in the valleys, oil palm and rubber monoculture plantations have been expanding into such sites. In the monoculture plantation, the study was set out to assess the influence of topography and flooding on water use pattern (Chapter 3).

On the other hand, mixed culture cultivation system is a potential way of obtaining ecological and economical services (McNeely and Schroth, 2006; Bhagwat et al., 2008), such as the existing complex admixed "jungle" rubber system in the lowlands of Sumatra (Clough et al., 2016). Regarding mixed-culture cultivation systems, tree water use and soil water uptake depth in rubber monoculture and jungle rubber stands with further focus on the role of tree diameter was studied (Chapter 4). The thermal dissipation probe (TDP) was applied with species specific calibration and also following the procedure of Niu et al. (2015) and Röll (2015) on palm and tree water use scheming; Stable water isotopes $\left(\delta^{18} \mathrm{O}\right.$ and $\left.\delta D\right)$ approach for assessing water uptake.

\subsection{Topography and flooding influence on transpiration}

To understand the influence of topography and flooding on mono-culture (i.e. oil palm and rubber tree) transpiration (Chapter 3), three plot pairs in each plantation type such in upland and adjacent valley site regarding flooded condition (i.e. non-, shortand long-term flooded valley) was established. To minimize other variables, similar age and cultivation practices for study plot was selected.

Flooded conditions in the valley sites of lowland Sumatra have different influence on oil palm and rubber tree water use pattern. At non-flooded valley, water use is higher than at upland site due to soil water availability. During the study period, soil water content at the non-flooded valley was at field capacity $37-40 \%$ ( $\mathrm{pF} \sim 2$, Kurniawan, unpublished data), while less soil water content was present around $28-30 \%$ in the upland. On the other hand, water use decreased in the flooded condition and much more decrease in the long-term flooded. Hypoxic and or anoxic condition during 
waterlogged decrease plant water uptake by reducing root hydraulic conductivity, stomatal closure and leaf hydraulic conductivity (Else et al., 2001; Nicolás et al., 2005; Atkinson et al., 2008; Aroca et al., 2012; Herrera, 2013; Zhao et al., 2014; Yan et al., 2015). In prolong waterlogged condition, water uptake capacities dropped significantly with less response of both plantation types in the long-term flooded valley to micrometeorological drivers.

Comparing response of oil palm and rubber plantation types, rubber tree showed much more pronounced water use heterogeneity due to topography and flooded condition. Compared to non-flooded upland sites, the different flooding conditions at valley sites amplified the observed heterogeneity of plot mean water use by a factor of 2.4 in oil palm and 4.2 in rubber plantations. Such differences between species in their water use response to flooding are influenced by differences in plant morphology, particularly the root and leaf system (Aroca et al., 2012; Kreuzwieser and Rennenberg, 2014; Miyazawa et al., 2014).

At the long term flooded valley areas which are usually at riparian areas, significant drop in oil palm and rubber tree water use and less response to micrometeorological drivers (i.e. VPD and $R_{g}$ ) indicated that both plantations are not appropriate in riparian areas. Water use has positive correlation to net primary production (NPP) and VPD (Chen and Coughenour, 2004). Decreasing palm oil until 20\% was reported in Malaysia (Ahamad et al., 2009; USDA, 2015) and dropped around 50\% of net photosynthesis by rubber tree due to prolong flooding period (de Carvalho et al., 2015). Furthermore, Capon et al. (2013) stressed on the need for riparian ecosystem conservation due to their important functions and vulnerability to climate change over coming century. Thus, the reasons of inappropriate riparian site for oil palm and rubber plantations are due to both dramatic decline in transpiration and increasing ecosystem functions such as biodiversity enrichment (Gray et al. 2014), reducing erosion and nutrient losses (e.g. Srivastava et al., 2010) and increasing water quality (Buffler et al., 2005). Due to significant decrease in rubber tree water uptake at the short term flooded valley and increase at the non-flooded valley, it suggest that rubber tree is more suitable to upland and non-flooded valley site. However oil palm can probably better cope with the short-term flooded valley. 


\subsection{Mixed-culture cultivation systems}

To compromise economical (i.e. palm oil and natural latex rubber production) and ecological concern at the excluding riparian area, water use and uptake study in different cultivation systems was conducted (i.e. rubber monoculture and admixed jungle rubber, Chapter 4). Four study plots of each cultivation system located in the upland sites was set up. All studied plot was small holder with similar age and slope gradient. Individual tree for xylem isotopes samples for water use measurement were collected during dry periods.

Based on tree water use, less transpiration of rubber monoculture in the lowland Sumatra than reported in Mainland Asia by Tan et al. (2011) was found. Rubber tree water use in both cultivation systems showed similar (non-significant different) values (mean $\pm \mathrm{se}$ ) $25.6 \pm 3.7$ and $24.1 \pm 4.2 \mathrm{~kg} \mathrm{~d}^{-1}$ for rubber tree in monoculture and jungle rubber respectively. Higher stand transpiration in the jungle rubber than rubber monoculture is mainly the effect of high stem density in the jungle rubber. Transpiration from the eight stands was strongly correlation with stem density $\left(r^{2}=0.85, p<0.01\right)$. In water uptake study, rubber tree in the jungle rubber mainly took up water from deeper soil depth (40-60 cm depth) than monoculture (20-40 cm depth) during dry period. However, admixed native tree species mainly took up water closer to top soil (20-40 cm depth). This indicated that rubber tree is a weak competitor when competition occurred. For the tree diameter role playing, increasing rubber tree water use with increasing tree diameter in both cultivation system was 2-fold higher than admixed native tree species.

This findings imply that jungle rubber, which provide higher ecosystem services (Clough et al., 2016) and stand transpiration (28\%) than rubber monoculture is a promising way to produce "greener" rubber product. However, to keep existing jungle rubber, farmer also needs to increase the economic value. To increase productivity and added value, farmer can increase productivity by increasing rubber density through regulation in native tree composition by considering economic value such as: timber, fruit, handicraft material and medicine (e.g. Lehébel-Péron, et al., 2011; Teuscher et al., 2016). Jungle rubber is also provide additional benefit such as less intensive rubber monoculture management by higher nitrogen stock (Allen et al., 2015) and less labor e.g. weeding (Joshi et al., 2002; Drescher et al., 2016) which can increase economic return (Lehébel-Péron et al., 2011). 
On the other hand, oil palm mixed culture in the upland site was established by B11sub project of EFForTS since 2013 (Teuscher et al., 2016). Stakeholders in the oil palm business often claim that tree - oil palm mixtures would not be a viable option, because of the tree palm competition in particular regarding water resources. A similar approach as conducted for the jungle rubber is now needed for the tree-palm mixture.

\subsection{Outlook and further research}

To deeper understand the influence of space and time on tree water use pattern, information across seasons with different water resources (under water stress due to waterlogged or drought; and climatic condition). Based on the promising result of the rubber with different cultivation systems, evaluation of water use and uptake on oil palm mixed culture is needed. Interventions for increasing stem density for increasing latex productivity should consider optimum threshold of biodiversity. 


\section{References}

Ahamad, M. S. S., Ali, R. Zakaria, N. A., Ghani, A. A. B., and Chang, C. K. (2009). "Flood loss assessment of the 2003 Muda River flood," in Third International Conference on Managing Rivers in the 21st Century: Sustainable Solutions for Global Crisis of Flooding, Pollution and Water Scarcity. 6-9 $9^{\text {th }}$ December 2011, Penang, Malaysia.

Allen, K., Corre, M. D., Tjoa, A., and Veldkamp, E. (2015). Soil nitrogen-cycling responses to conversion of lowland forests to oil palm and rubber plantations in Sumatra, Indonesia. PloS One 10:e0133325. doi: 10.1371/journal. pone. 0133325

Aroca, R., Porcel, R., and Ruiz-Lozano, J. M. (2012). Regulation of root water uptake under abiotic stress conditions. J. Exp. Bot. 63, 43-57. doi: 10.1093/jxb/err266

Atkinson, C. J., Harrison-Murray, R. S., and Taylor, J. M. (2008). Rapid flood-induced stomatal closure accompanies xylem sap transportation of root-derived acetaldehyde and ethanol in Forsythia. Environ. Exp. Bot. 64, 196-205. doi:10.1016/j.envexpbot.2008.02.001

Bhagwat, S. A., Willis, K. J., Birks, H. J. B., and Whittaker, R. J. (2008). Agroforestry: a refuge for tropical biodiversity? Trends Ecol. Evol. 23, 261-267. doi:10.1016/j.tree.2008.01.005

Buffler, S., Johnson, C., Nicholson, J., and Mesner, N. (2005). Synthesis of design guidelines and experimental data for water quality function in agricultural landscapes in the intermountain west. USDA For. Serv. Fac. Publ., 13. Available online at: http://digitalcommons.unl.edu/usdafsfacpub/13 (Accessed December 20, 2016).

Capon, S. J., Chambers, L. E., Nally, R. M., Naiman, R. J., Davies, P., Marshall, N., et al. (2013). Riparian ecosystems in the 21st century: hotspots for climate change adaptation? Ecosystems 16, 359-381. doi: 10.1007/s10021-013-9656-1

Chen, D. X., and Coughenour, M. B. (2004). Photosynthesis, transpiration, and primary productivity: scaling up from leaves to canopies and regions using process models and remotely sensed data. Glob. Biogeochem. Cycles 18:GB4033. doi:10.1029/2002GB001979

Clough, Y., Krishna, V. V., Corre, M. D., Darras, K., Denmead, L. H., Meijide, A., et al. (2016). Land-use choices follow profitability at the expense of ecological functions in Indonesian smallholder landscapes. Nat. Commun. 7:13137. doi:10.1038/ncomms13137

de Carvalho, P. A., Lira, J. M. S., de Oliveira, L. E. M., de Carvalho, J. N., Domiciano, D., and Cárdenas, H. B. W. (2015). Nitrate addition improves photosynthesis and flooding tolerance of rubber tree plants. Aust. J. Crop Sci. 9, 684-689.

Drescher, J., Rembold, K., Allen, K., Beckschäfer, P., Buchori, D., Clough, Y., et al. (2016). Ecological and socio-economic functions across tropical land use systems after rainforest conversion. Phil. Trans. R. Soc. B. 371:20150275. doi:10.1098/rstb.2015.0275 
Else, M. A., Coupland, D., Dutton, L., and Jackson, M. B. (2001). Decreased root hydraulic conductivity reduces leaf water potential, initiates stomatal closure and slows leaf expansion in flooded plants of castor oil (Ricinus communis) despite diminished delivery of ABA from the roots to shoots in xylem sap. Physiol. Plant. 111, 46-54. doi: 10.1034/j.1399-3054.2001.1110107.x

Fitzherbert, E. B., Struebig, M. J., Morel, A., Danielsen, F., Brühl, C. A., Donald, P. F., and Phalan, B. (2008). How will oil palm expansion affect biodiversity? Trends Ecol. Evol. 23, 538-545. doi: 10.1016/j.tree.2008.06.012

Gray, C. L., Slade, E. M., Mann, D. J., and Lewis, O. T. (2014). Do riparian reserves support dung beetle biodiversity and ecosystem services in oil palm-dominated tropical landscapes? Ecol. Evol. 4, 1049-1060. doi: 10.1002/ece3.1003

Herrera, A. (2013). Responses to flooding of plant water relations and leaf gas exchange in tropical tolerant trees of a black-water wetland. Front. Plant Sci. 4:106. doi: 10.3389/fpls.2013.00106

Joshi, L., Akiefnawati, R., Boutin, D., Manurung, G., van Noordwijk, M., Vincent, G., et al. (2002). Jungle rubber: A traditional agroforestry system under pressure. International Centre for Research in Agroforestry (ICRAF). Bogor. Indonesia. Available online at: http://www.worldagroforestry.org/publication/jungle-rubbertraditional-agroforestry-system-under-pressure (Accessed July 19, 2016).

Kreuzwieser, J., and Rennenberg, H. (2014). Molecular and physiological responses of trees to waterlogging stress: responses of tree to waterlogging. Plant Cell Environ. 37, 2245-2259. doi: 10.1111/pce.12310

Lehébel-Péron, A., Feintrenie, L., and Levang, P. (2011). Rubber agroforests' profitability, the importance of secondary products. For. Trees Livelihoods 20, 69-84. doi: 10.1080/14728028.2011.9756698

McNeely, J. A., and Schroth, G. (2006). Agroforestry and biodiversity conservationtraditional practices, present dynamics and lessons for the future. Biodivers. Conserv. 15, 549-554. doi: 10.1007/s10531-005-2087-3

Merten, J., Röll, A., Guillaume, T., Meijide, A., Tarigan, S., Agusta, H., et al. (2016). Water scarcity and oil palm expansion: social views and environmental processes. Ecol. Soc. 21:5. doi: 10.5751/ES-08214-210205

Miyazawa, Y., Tateishi, M., Komatsu, H., Ma, V., Kajisa, T., Sokh, H., et al. (2014). Tropical tree water use under seasonal waterlogging and drought in Central Cambodia. J. Hydrol. 515, 81-89. doi: 10.1016/j.jhydrol.2014.04.049

Nicolás, E., Torrecillas, A., Dell'Amico, J., and Alarcón, J. J. (2005). The effect of short-term flooding on the sap flow, gas exchange and hydraulic conductivity of young apricot trees. Trees 19, 51-57. doi: 10.1007/s00468-004-0362-7

Niu, F., Roll, A., Hardanto, A., Meijide, A., Kohler, M., Hendrayanto, and Holscher, D. (2015). Oil palm water use: calibration of a sap flux method and a field measurement scheme. Tree Physiol. 35, 563-573. doi:10.1093/treephys/tpv013

Röll, A. (2015). Changes in eco-hydrological functioning after tropical rainforest transformation to rubber and oil palm plantations. [Dissertation]. [Göttingen, Germany]. Available online at: https://ediss.uni-goettingen.de/handle/11858/001735-0000-0023-9641-F (Accessed July 26, 2016). 
Srivastava, N. K., Ram, L. C., and Masto, R. E. (2010). Role of selected riparian herbs in reducing soil erosion and nutrient loss under simulated rainfall. Environ. Earth Sci. 61, 405-417. doi:10.1007/s12665-009-0353-5

Tan, Z. H., Zhang, Y. P., Song, Q. H., Liu, W. J., Deng, X. B., Tang, J. W., et al. (2011). Rubber plantations act as water pumps in tropical China: rubber plantation act as water pumps. Geophys. Res. Lett. 38:L24406. doi:10.1029/2011GL050006

Teuscher, M., Gérard, A., Brose, U., Buchori, D., Clough, Y., Ehbrecht, M., et al. (2016). Experimental biodiversity enrichment in oil-palm-dominated landscapes in Indonesia. Front. Plant Sci. 7:1538. doi: 10.3389/fpls.2016.01538

USDA. (2015). Malaysia: 2014/15 palm oil production affected by flooding. Available online at: http://pecad.fas.usda.gov/highlights/2015/03/Malaysia/Index.htm (Accessed April 4, 2016).

Zhao, H. F., Zhao, Y., Zhang, C., Tao, X., and Xu, N. (2014). Growth, leaf gas exchange, and chlorophyll fluorescence responses of two cultivars of Salix integra Thunb. to waterlogging stress. J. Agric. Sci. Technol. 16, 137-146.

Yan, X. L., Xi, B. Y., Jia, L. M., and Li, G. D. (2015). Response of sap flow to flooding in plantations of irrigated and non-irrigated triploid poplar. J. For. Res. 20, 375385. doi: 10.1007/s10310-015-0485-2 


\section{List of figures}

Pg.

Figure 1.1. (a) Annual primary forest covers loss in Indonesia during 20002012 (Margono et al., 2014). (b) Land use change, 1990-2011, for two landscape region (i.e. Bukit duabelas and Harapan region) in lowland of Jambi (Clough et al., 2016).

Figure 1.2. Undulating landscape transect between two major rivers in Jambi Province. In the past, the area was characterized by heterogeneous land use, such as: 1 . jungle rubber; 2 . wetland rice and pasture; 3. Settlement and fruit orchards; 4 . River; 5. Logged over forest; 6 . Rubber estate plantation (transmigration); 7. Road; and 8. Oil palm state plantation. Recently, oil palm and rubber plantation become the dominant crop in Jambi province (Gouyon et al., 1993; Drescher et al., 2016).

Figure 2.1. Location of EFForTS study sites in Jambi province, Sumatra, Indonesia. The core plot design is located in two landscapes, namely Bukit Duabelas and Harapan region. All the study plot located in Harapan region (Drescher et al., 2016).

Figure 3.1. The study region ('Harapan region') in Jambi province, Sumatra, Indonesia. Location of oil palm and rubber plot pairs (each consisting of upland and valley sites). Upland sites were part of the larger experimental design of the EFForTS project (Drescher at al. 2016) and had plot codes $\mathrm{H}$ (for Harapan) with $\mathrm{O}$ for oil palm and $\mathrm{R}$ for rubber; numbering goes from South to North. The terrain of the landscape is undulating, as to be seen on a digital surface model (DSM, Naumann, 2015) of a 627 ha region in an oil palm plantation owned by PT. Humusindo, approximately $10 \mathrm{~km}$ south of our study region (indicated by brown rhombus).

Figure 3.2. In oil palm and rubber plantations, plot pairs consisting of upland and adjacent valley sites were studied, with three replicates for each plantation type. In the study period, the upland plots were never flooded, whereas the valley plots comprised non-flooded, long-term flooded, and short-term flooded conditions. Within each plot pair, sap flux measurements were conducted simultaneously at the upland and according valley site. 
Pg.

Figure 3.3. Oil palm (left panel) and rubber (right) plot pairs with nonflooded valley. Diurnal course of sap flux density $\left(J_{s}\right)$ at the upland (brown) and corresponding non-flooded valley site (blue). Hourly means of three sunny days; vertical bars show the standard error of the mean in sap flux among rubber trees ( $n=6$ trees; each with two sensors) and oil palms ( $n=4$ palms; each with four leaves and one sensor per leaf) in a plot at a given time.

Figure 3.4. Oil palm (left panel) and rubber (right) plot pairs with long-term flooded valley. Diurnal course of sap flux density $\left(J_{s}\right)$ at the upland (brown) and corresponding long-term flooded valley site (blue). Hourly means of three sunny days; vertical bars show the standard error of the mean in sap flux among rubber trees ( $n=6$ trees; each with two sensors) and oil palms ( $n=4$ palms; each with four leaves and one sensor per leaf) in a plot at a given time.

Figure 3.5. Oil palm (left panel) and rubber (right) plot pairs with long-term flooded valley. Daily accumulated sap flux density $\left(J_{s}\right)$ in response to changes in average daily vapor pressure deficit (VPD) at the upland (green) and corresponding long-term flooded valley site (blue). Plot pairs were $\mathrm{HO} 3$ for oil palm and HR1 for rubber.

Figure 3.6. Oil palm (left panel) and rubber (right) plot pairs with long-term flooded valley. Daily accumulated sap flux density $\left(J_{s}\right)$ in response to to changes in global radiation daysums $\left(R_{\mathrm{g}}\right)$ at the upland (green) and corresponding long-term flooded valley site (blue). Plot pairs were $\mathrm{HO} 3$ for oil palm and HR1 for rubber.

Figure 3.7. Oil palm (left panels) and rubber (right) plot pairs with shortterm flooded valley. Flooded and non-flooded conditions at the valley sites are compared. Diurnal course of sap flux density $\left(J_{s}\right)$ at upland (upper panels) and corresponding valley sites (lower). Upland sites were always non-flooded, but valley sites varied between non-flooded (green) and short-term flooded (blue) conditions. For the according periods (i.e. valley nonflooded, valley short-time flooded), upland $J_{s}$ as a reference is displayed separately (in green and blue, respectively). Hourly values on a sunny day; vertical bars show the standard error of the mean in sap flux among rubber trees ( $n=6$ trees; each with two sensors) and oil palms ( $n=4$ palms; each with four leaves and one sensor per leaf) in a plot at a given time. 
Pg.

Figure 3.8. Long-term, short-term and non-flooded plot pairs combined. Water use by oil palm and rubber trees across upland and valley plots, normalized by mean oil palm (A) and rubber tree (B) water use on the upland plots (sunny days, means and standard errors). Short term flooded valley plots are given twice, once under flooded (closed symbols) and once under non-flooded (open symbols) conditions. Dynamics of the heterogeneity of normalized water use (C and D) and normalized transpiration ( $E$ and $F$ ) of oil palm and rubber from upland to valley plots. Displayed factors quantify the heterogeneity that is induced as a result of topographic position and flooded conditions at valley sites in relation to the heterogeneity at upland sites.

Figure 4.1. The study region in Jambi province, Indonesia. The study was conducted in the Harapan region and consists of four plots each in rubber monoculture $(\mathrm{HR})$ and jungle rubber $(\mathrm{HJ})$ stands.

Figure 4.2. Percentage of water uptake from different soil depths based on $\delta^{18} \mathrm{O}$ analyses and the application of a SIAR mixing model. Means and standard errors; $\mathrm{n}=21$ (rubber trees in monoculture), $n=14$ (rubber tree in jungle rubber), and $n=10$ (admixed native trees in jungle rubber). Small letters indicate significant vertical differences of fractional water uptake within a cultivation type; significant horizontal differences within a given depth across cultivation types are indicated by capital letters $(p<0.05$; ANOVA).

Figure 4.3. Maximum sap flux density $\left(J_{s \operatorname{smax}}\right)$ and tree water use on sunny days, and xylem isotopic $\delta^{18} \mathrm{O}$ signatures, in relation to tree diameter for rubber trees in monocultures and for rubber trees and admixed native tree species in jungle rubber stands.

Figure 4.A1. Relationship between Xylem water $\delta^{18} \mathrm{O}(\%)$ and $\delta D(\%)$ for 68 soil water (A) and xylem water (B). The lines indicate a 1:1 relationship.

Figure 4.A2. Isotopic $\delta^{18} \mathrm{O}$ signatures of plant and gravimetric soil water (with increasing depth) for the sample trees in our study. Data of all land use types and species pooled. Values are means \pm sd $(n=45)$. 
Pg.

Figure 4.A3. Percentage of water uptake from different soil depths as based 70 on $\delta D$ analyses and the application of a SIAR mixing model. Means and standard errors; $n=21$ (rubber monoculture), $n=14$ (rubber trees in jungle rubber), and $n=10$ (admixed native trees in jungle rubber). Small letters indicate significant vertical differences of fractional water uptake within a cultivation type; significant horizontal differences within a given depth across cultivation types are indicated by capital letters ( $p<0.05$; ANOVA).

Figure 4.A4. Xylem $\delta D$ in relation to tree diameter for rubber trees in monocultures and for rubber trees and admixed native tree species in jungle rubber stands.

Figure 4.A5. Stand transpiration plotted against basal area (a) and stand density (b). Data for eight plots encompassing rubber monocultures ( $n=4$, blue rhombuses) and jungle rubber stands $(n=4$, green circles). 


\section{List of tables}

Pg.

Table 3.1. Stand characteristics and moisture conditions at the different topographic positions in oil palm and rubber plantations.

Table 3.2. Maximum sap flux density $\left(J_{s \max }\right)$ in oil palm leaf petioles and 36 rubber tree trunks, water use per palm and tree and estimated stand transpiration rates at upland and valley plots under varying flooding conditions i.e. non-flooded, long-term and short-term flooded (sunny days, means and standard errors).

Tabel 4.1. Tree and stand characteristics of the studied rubber monocultures and jungle rubber stands.

Tabel 4.2. Maximum sap flux density $\left(J_{s \max }\right)$, water use, and stand transpiration of the rubber monoculture and jungle rubber stands (sunny days, mean and standard errors, $\mathrm{n}=4$ each).

Table 4.A.1. Study period and environmental characteristics (three sunny days, means and standard errors) in the respective study plots in rubber monoculture plantations and jungle rubber stands. 


\section{ACKNOWLEDGMENTS}

In this moment, I just want to say "Alhamdulillah" as He has blessed me with great people around me to accomplish my dissertation:

I would like to thank Prof. Dr. Dirk Hölscher immensely for his great discussion, friendly guidance and strong support not only in academic scope but also nonacademic during my study. It would difficult and impossible for me to finish my Dissertation without his advice and guidance. My gratitude to Prof. Dr. Alexander Knohl and Prof. Dr. Hermann Behling for acceptance to be on the exam commission.

I would also like to thank the Indonesian Directorate General of Higher Education (DIKTI) and Deutscher Akademischer Austauschdienst (DAAD) through IndonesianGermany Scholarship Program (IGSP) for my PhD scholarship. I also thank the Deutsche Forschungsgemeinschaft (DFG) as part of AO2-sub project and Access and Benefit Sharing (ABS) project for the research funding. I am pleased thankful to all EFForTS member for collaboration and cooperation.

And I never forget my great team and nice guys in AO2 (Alex, Niu and Andrea) for our team work during "crazy" field work, discussion and finishing our work! I thank also to my field assistants Ali, Davig, Ferry and Bayu as all of you, our field work can be successful! My particular gratitude goes to my "families" in Jambi: Rozi, pak Apri, Babe, pak Diton and mas Paino for helping me during flood at midnight "11 pm until $02 \mathrm{am}$ " in the field. I will back to Jambi again, Insyaallah.

I am also very thankful to Frau Eva Siegelkow for helping me especially with "complicated" administration but made easier for me! Thanks also to the friendly and nice atmosphere of all colleagues at our department. My next acknowledgement goes to Abdulai for sharing our culture, field study and correcting my "In-Nglish". I deeply thank also for all Indonesian in Göttingen as make this city like my hometown. To pak Erwin's family, many thanks for the memorable journey and warm family, later we can make other destination in Indonesia.

"Behind every successful man there is a woman" thus my deepest gratitude to my wife Lily Alawiyah and "Trio shalihin-Jungen: Syaffa, Syamil and Silmi" for all the love and patience. You all gave me the energy and determination to stay stronger and never give up till the end. Finally, I would like to dedicate my Dissertation to "simbok" and "bapak", hopefully you are happy and peace in Jannah. 


\section{DECLARATION OF HONOR}

I hereby declare that I am the sole author of this dissertation entitled "Oil palm and rubber tree transpiration: topography, flooding and tree admixture in jungle rubber stands" and that all references and data sources used have been acknowledged as such. I further declare that this work has never been submitted in any form as part of other dissertation procedures.

Göttingen, January 2017

(Afik Hardanto) 


\section{CURRICULUM VITAE}

\section{Afik Hardanto}

Date of birth : 19 October 1980

Place of birth : Bantul, Indonesia

Gender : Male

Citizenship : Indonesian

\section{Education}

2013-present

: Ph.D. in Tropical Silviculture and Forest Ecology,

Faculty of Forest Sciences and Forest Ecology,

Georg-August-Universität Göttingen

2009-2011

: M.Sc. in Agricultural Engineering, Faculty of Agricultural

Technology, Gadjah Mada University, Indonesia

2000-2005

: B.Sc. in Agricultural Engineering, Faculty of Agricultural

Technology, Gadjah Mada University, Indonesia

\section{List of Publications}

Niu, F.*, Röll, A.*, Hardanto, A., Meijide, A., Hendrayanto, Hölscher, D. (2015). Oil palm water use: calibration a sap flux method and a field measurement scheme. Tree Physiol. 35, 563-573, doi: 10.1093/treephys/tp-v013

Röll, A.*, Niu, F.*, Meijide, A., Hardanto, A., Hendrayanto, Knohl, A., Hölscher, D. (2015). Transpiration in an oil palm landscape: effects of palm age. Biogeosciences 12, 5619-5633, doi: 10.5194/bg-12-5619-2015

\section{Conferences}

Hardanto, A., Röll, A., Niu, F., Hanf, A., Junedi, H., Hendrayanto, Hölscher, D., Water use by rubber and oil palm plantations in the lowlands of Jambi, Indonesia. Tropentag 2014, Prague, Czech Republic.

Röll, A., Niu, F., Hardanto, A., Hanf, A., Junedi, H., Herdhata, A., Hendrayanto, Hölscher, D.: Oil palm vs. forest: variability in sap flux based stand water use. IUFRO World Congress 2014, Salt Lake City, USA.

Niu, F., Röll, A., Hardanto, A., Meijide, A., Junedi, H., Herdhata, A., Hendrayanto, Knohl, A., Hölscher, D. Transpiration in an oil palm landscape: effects of palm age. ATBC 2015, Honolulu, USA. 